Universidade de Brasília - UnB

Faculdade UnB Gama - FGA

Curso de Engenharia Eletrônica

SISTEMA ELETRÔNICO DE TELEMETRIA POR GPRS APLICADO À COLETA DE RESÍDUOS DE EMBALAGENS DE VIDRO

Autor: Felipe Thiago Morais Aguiar Orientador: Prof. Dr. Guillermo Alvarez Bestard

\title{
Brasília, DF
}

2018 
Felipe Thiago Morais Aguiar

\section{SISTEMA ELETRÔNICO DE TELEMETRIA POR GPRS APLICADO À COLETA DE RESÍDUOS DE EMBALAGENS DE VIDRO}

Monografia submetida ao curso de graduação em Engenharia Eletrônica da Universidade de Brasília, como requisito parcial para obtenção do Título de Bacharel em Engenharia Eletrônica.

Orientador: Prof. Dr. Guillermo Alvarez Bestard

Brasília, DF 
Thiago Morais Aguiar, Felipe

SISTEMA ELETRÔNICO DE TELEMETRIA POR GPRS APLICADO À

TSI623s COLETA DE RESÍDUOS DE EMBALAGENS DE VIDRO / Felipe Thiago Morais Aguiar; orientador Guillermo Alvarez Bestard. -Brasilia, 2019.

$92 \mathrm{p}$.

Monografia (Graduação - Engenharia Eletrônica) -Universidade de Brasilia, 2019.

1. Embalagens de vidro. 2. GPRS. 3. monitoramento remoto. 4. otimização. 5. resíduos. I. Alvarez Bestard, Guillermo, orient. II. Título. 


\section{UnBGama \\ O novo endereço da tecnologia}

\section{SISTEMA ELETRÔNICO DE TELEMETRIA POR GPRS APLICADO À COLETA DE RESÍDUOS DE EMBALAGENS DE VIDRO}

\section{Felipe Thiago Morais Aguiar}

Monografia submetida como requisito parcial para obtenção do Título de Bacharel em Engenharia Eletrônica da Faculdade UnB Gama - FGA, da Universidade de Brasília, em 05 de julho de 2019 apresentada e aprovada pela banca examinadora abaixo assinada:

Professor Dr. Guillermo Alvarez Bestard, UnB/ FGA

Orientador

Professor Dr. Daniel M. Muñoz Arboleda, UnB/ FGA

Convidado 1

Professor Dr. Renato Coral Sampaio, UnB/ FGA

Convidado 2

Brasília, DF

2019 


\section{AGRADECIMENTOS}

A Deus por ter me proporcionado saúde e força para enfrentar as dificuldades encontradas no percurso deste trabalho e do curso de graduação.

A meus pais pelo apoio e companheirismo.

A professora orientadora Maria Vitória, que com muita paciência se esforçou para me guiar no caminho de um ótimo trabalho. A parabenizo também pela sua coragem em aceitar um desafio tão incerto.

A professora Josiane pelas tardes de conselhos e dicas que me ajudaram a desenvolver verdadeiramente o trabalho.

Ao professor Cristian Venditozzi pelo cuidado, interesse e disponibilidade em sempre ajudar.

Ao professor Guillermo pela parceria e ajuda na conclusão da segunda etapa do trabalho. Onde me estimulou a pensar criticamente e auxiliou no desenvolvimento do sistema eletrônico verdadeiramente funcional.

E a todos que puderam me apoiar direta ou indiretamente e fizeram parte da minha formação. 


\section{RESUMO}

À medida que o ser humano usufrui dos recursos naturais, os mesmos se tornam escassos e ações como a reciclagem e reutilização são necessárias para garantir sua melhor utilização. Com intuito de contribuir para a cadeia de reciclagem dos resíduos de vidro no Distrito Federal, este trabalho tem o objetivo de elaborar um sistema eletrônico de monitoramento remoto do nível de embalagens de vidro em contêineres para coleta deste resíduo. O sistema irá monitorar o nível em cada contêiner, através de um sensor de ultrassom, e o estado da bateria do sistema eletrônico de aquisição de dados. As grandezas obtidas pela interface instalada em cada contêiner são transmitidas para um servidor web, por meio de comunicação GPRS e por meio de solicitações GET sobre o protocolo HTML e TCP/IP. Essas grandezas, além da configuração do sistema e dos containers, são armazenadas em uma base de dados SQL. O sistema eletrônico desenvolvido é o primeiro estágio para um sistema maior que possa indicar quais contêineres devem ser coletados e o melhor curso para a coleta, de maneira a obter um aumento da sua eficiência. Visando o desenvolvimento futuro do sistema e sua viabilidade, foram entrevistados possíveis clientes. O estudo apresentou uma economia estimada de $26,6 \%$ nos gastos com transporte da empresa analisada. A simulação eletrônica e os testes físicos da interface demonstraram a funcionalidade prática do dispositivo.

\footnotetext{
Palavras-chave: Embalagens de vidro, GPRS, monitoramento remoto, otimização, resíduos.
} 
ABSTRACT

Insofar human beings consume natural resources, the shortage become eminent, actions such as recycling and reuse are necessary to ensure their best use. In order to contribute to the glass waste recycling chain in the Federal District, this work has the objective of elaborating an electronic system for remote monitoring of the level of glass containers in containers for the collection of this residue. The system will monitor the level in each container, through an ultrasonic sensor, and the battery status of the electronic data acquisition system. The quantities obtained by the interface installed in each container are transmitted to a web server, through GPRS communication and the GET method over HTML and TCP / IP. These quantities, in addition to the configuration of the system and containers, are stored in a SQL database. The developed electronic system is the first stage for a larger system that can indicate which containers are to be collected and the best course for collection in order to increase its efficiency. Aiming at the future development of the system and its feasibility, potential customers were interviewed. The study presented an estimative saving of $26.6 \%$ in transportation costs of the company analyzed. The electronic simulation and the physical tests of the interface demonstrated the practical functionality of the device.

Keywords: Glass packaging, GPRS, remote monitoring, optimization, waste. 


\section{LISTA DE ILUSTRAÇÕES}

Figura 1. Gravimetria dos resíduos domiciliares do Distrito Federal ........................17

Figura 2. Resíduos misto de embalagem de vidro ...........................................18

Figura 3. (a) Caminhão modelo Rollon-rolloff (b) Caminhão Poliguindaste com caixa Dempster

Figura 4. Processo de beneficiamento dos resíduos de vidro na Vidro Porto 20

Figura 5. Etapas do processo de recuperação dos resíduos de embalagens de vidro .21

Figura 6. Comparativo de gasto de matéria prima na fabricação do vidro 22

Figura 7. Bombonas plásticas para coleta de resíduos de vidro .28

Figura 8. Contêiner utilizado para coleta de resíduos de embalagem de vidro .29

Figura 9. Pontos e rotas de transporte de resíduos da empresa GreenAmbiental ....30

Figura 10. Fluxo de operação de um sistema de telemetria 31

Figura 11. Diagrama esquemático do sistema de telemetria. .43

Figura 12. Sim 800L da empresa Core Board .44

Figura 13. Circuito regulador de tensão 44

Figura 14. Sensor de ultrassom HC-SR04P 46

Figura 15. Microcontrolador ATtiny 85 49

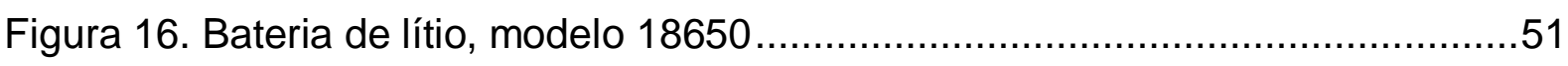

Figura 17. Fluxograma principal do código de programação...................................54

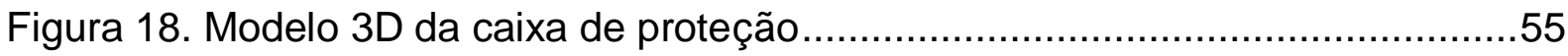

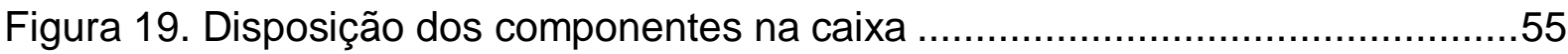

Figura 20. Módulo carregador TP4056 para baterias de lítio de $3,7 \mathrm{~V}$.....................56

Figura 21. Tensão e corrente durante o carregamento das baterias.........................57

Figura 22. Esquema para carregamento de baterias em dois contêineres. ...............57

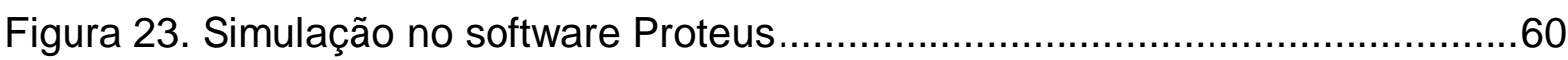

Figura 24.Gráfico gerado pelo osciloscópio nas simulações.....................................61

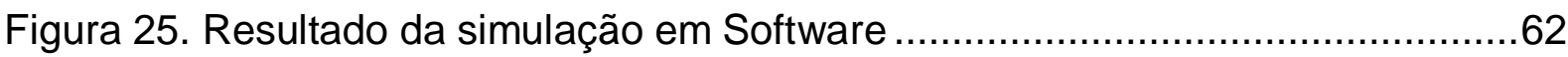

Figura 26. Possíveis respostas do módulo SIM800L ……....................................63

Figura 27. Esquemático para elaboração da PCB ...................................................64

Figura 28. Projeto placa de circuito impresso .......................................................64

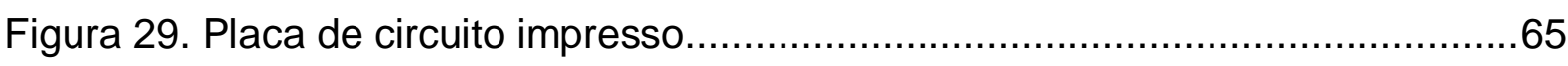

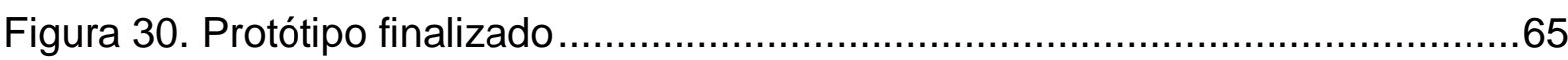


Figura 31. Base de dados relacional ...... .66

Figura 32. Esquemático para carregar o script no ATtiny 85..................................67

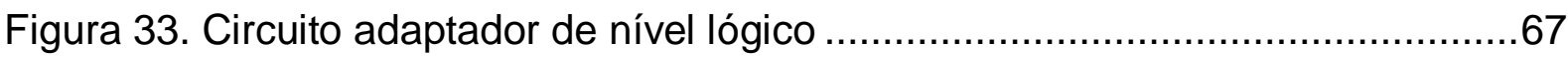

Figura 34. Respostas aos comandos AT enviados ao SIM800L ............................68

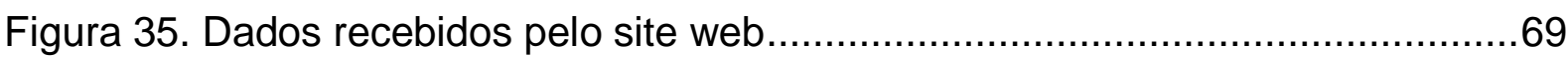

Figura 36. (a) Teste de reflexão das ondas sonoras (b) posicionamento do sensor .73

Figura 37. Dimensões físicas do container.............................................................90

Figura 38. Caminhão Poliguindaste Duplo Articulado, modelo Constalation 17.280 .90

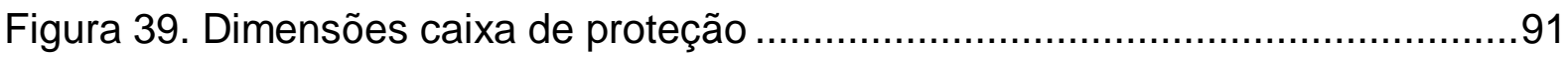

Figura 40. Dimensões tampa da caixa de proteção ………..................................

Figura 41. Fluxogramas da forma tradicional (a) e forma otimizada (b) ..................92

\section{LISTA DE TABELAS}

Tabela 1. Localização geográficas dos pontos de coleta .......................................30

Tabela 2. Classificação do espectro eletromagnético ............................................35

Tabela 3. Matriz de distância entre os pontos de interesse......................................39

Tabela 4. Simulação da proposta nas duas formas de trabalho ...............................41

Tabela 5. Informações relevantes sobre os microcontroladores analisados ..............48

Tabela 6. Lista de Comandos AT utilizados ............................................................53

Tabela 7.Custos componentes do subsistema remoto .........................................58

Tabela 8.Custo total dos componentes do subsistema central ..............................59

Tabela 9. Comandos usados na comunicação com o servidor web..........................66

Tabela 10. Teste amostral de medidas ..........................................................

Tabela 11. Teste do erro máximo aferido dentro da faixa de trabalho ......................71

Tabela 12. Teste de da resolução de medição do sistema ......................................73

Tabela 13. Corrente aferidas em laboratório ...................................................... 74

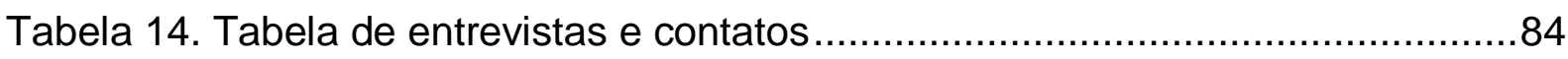




\section{SUMÁRIO}

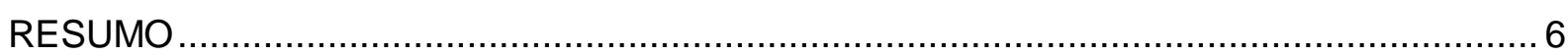

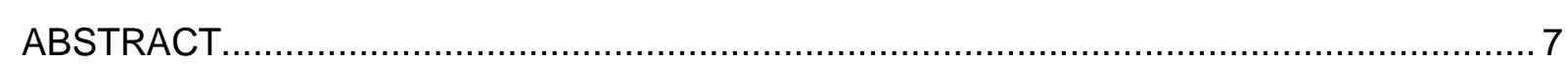

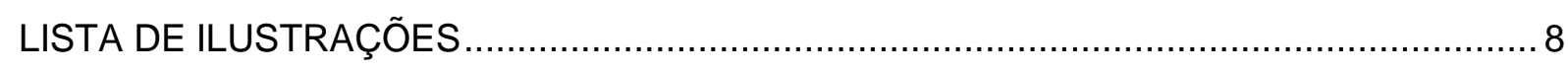

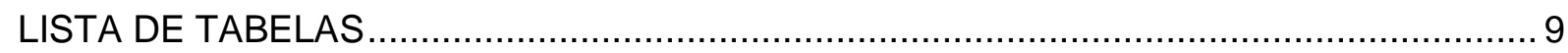

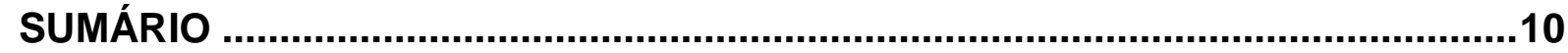

1. INTRODUÇÃO ...........................................................................................12

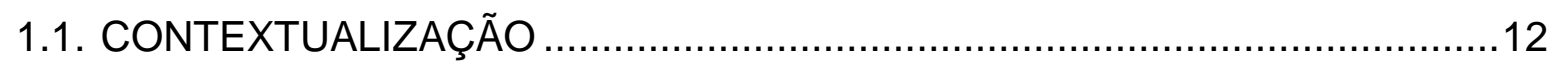

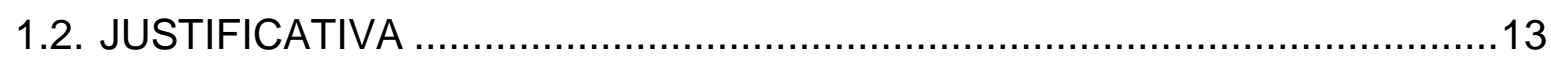

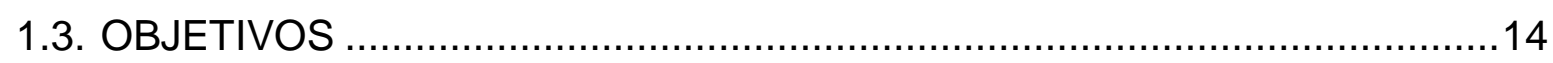

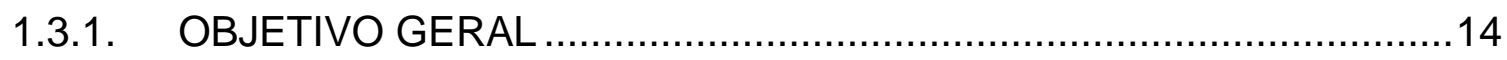

1.3.2. OBJETIVOS ESPECÍFICOS .................................................... 14

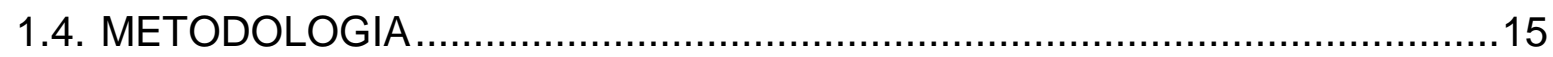

2. RESÍDUOS DE EMBALAGEM DE VIDRO NO BRASIL ................................17

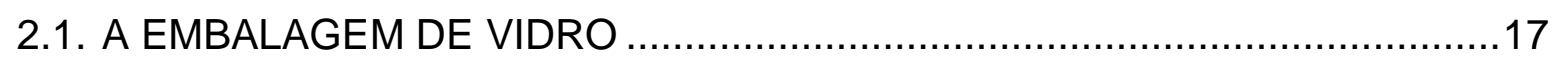

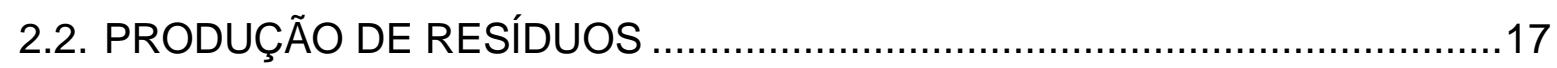

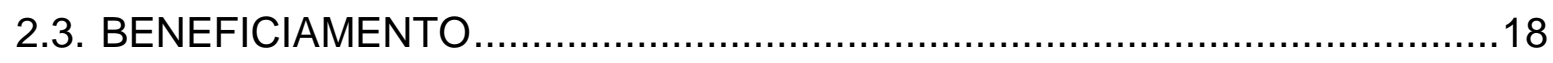

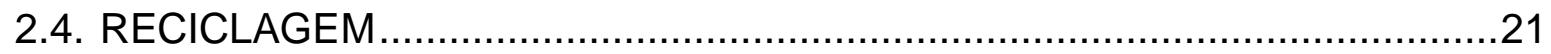

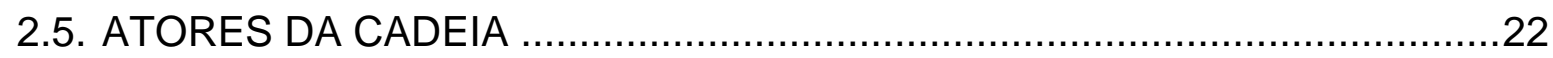

2.6. INSTRUMENTOS DE REGULAÇÃO ................................................23

2.7. COLETA DOS RESIDUOS DE VIDRO NO DISTRITO FEDERAL ...............26

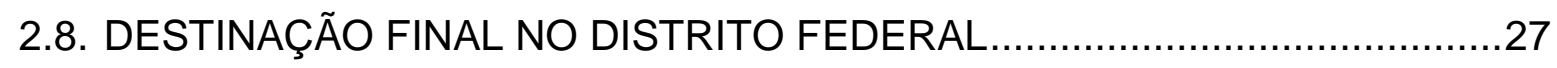

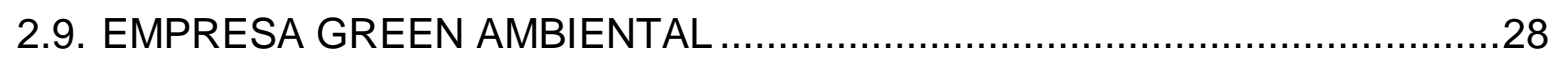

3. TELEMETRIA .......................................................................................30

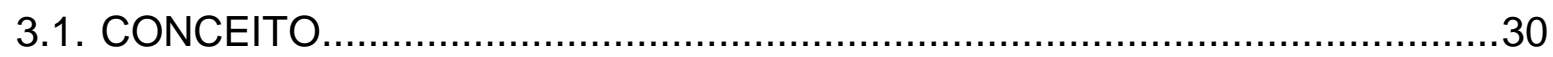

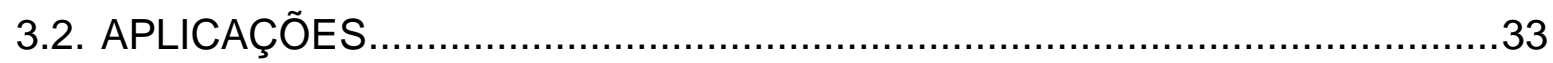

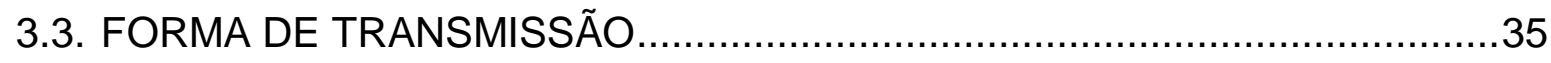

3.3.1. TRANSMISSÃO POR MICRO ONDAS ........................................ 35

3.3.2. TRANSMISSÃO DE DADOS VIA SATÉLITE.................................... 35

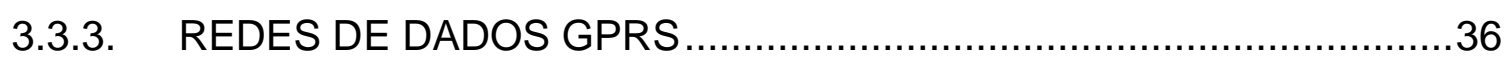

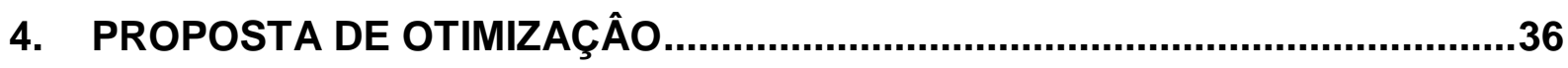

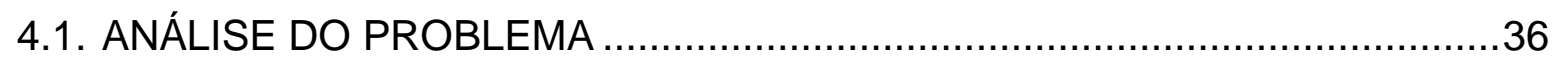

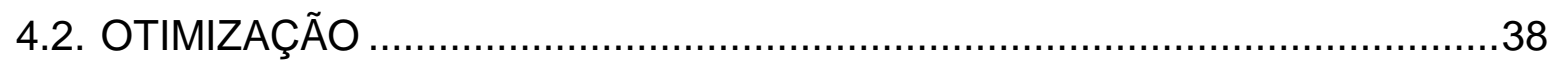

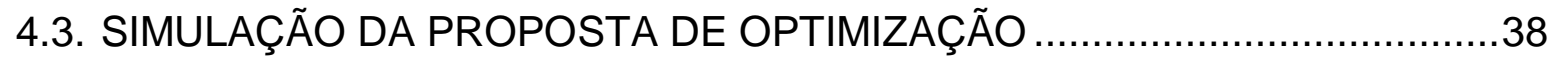




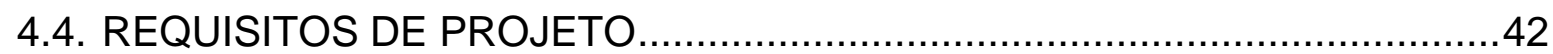

5. DESENHO DO SISTEMA DE TELEMETRIA …............................................. 43

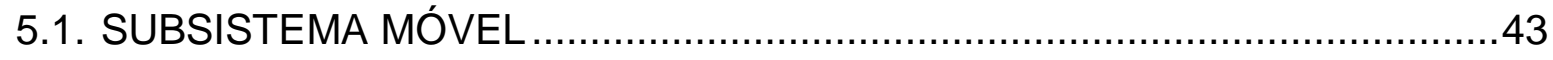

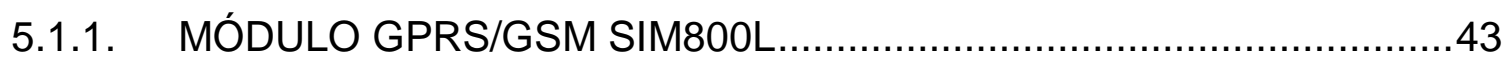

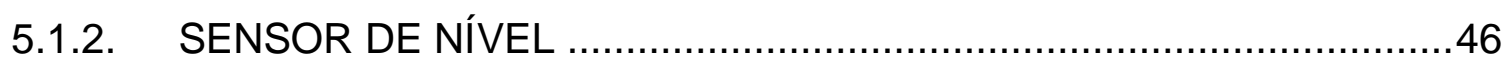

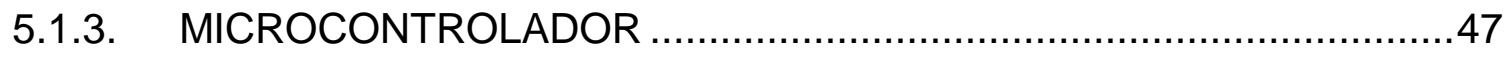

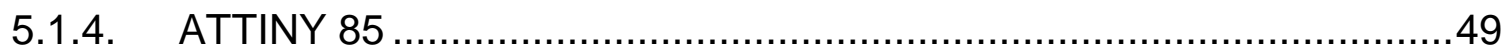

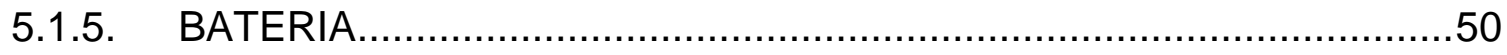

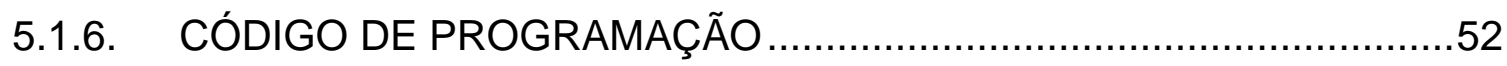

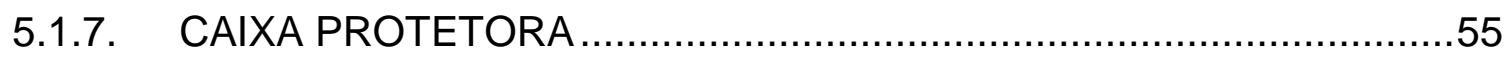

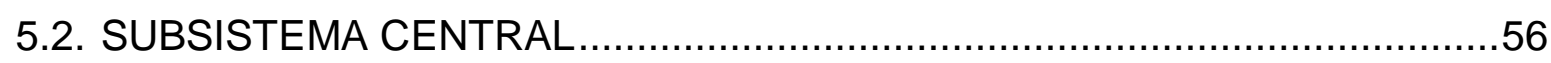

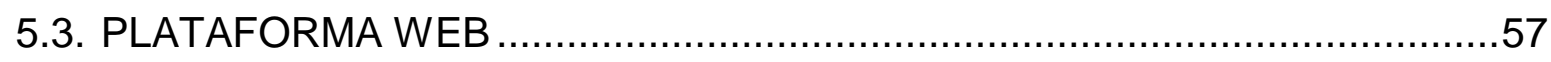

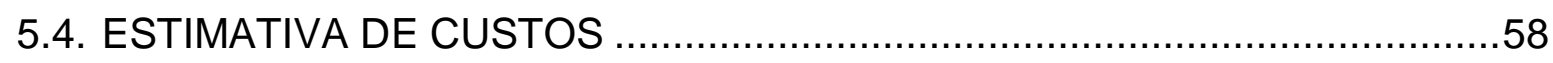

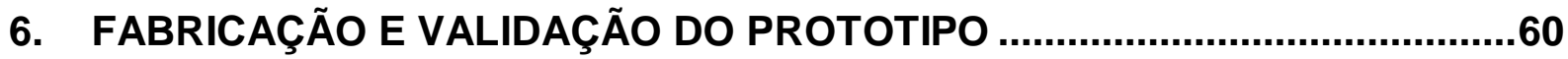

6.1. SIMULAÇÃO DO CIRCUITO ELETRÔNICO..............................................60

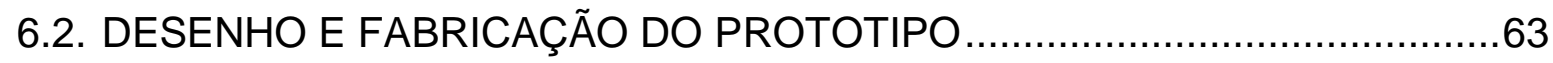

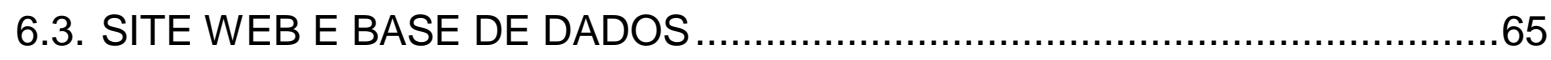

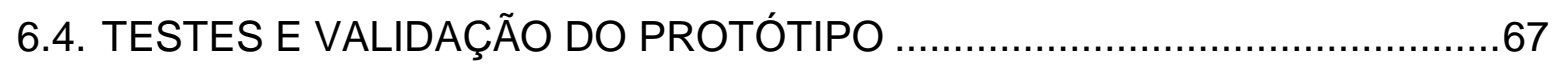

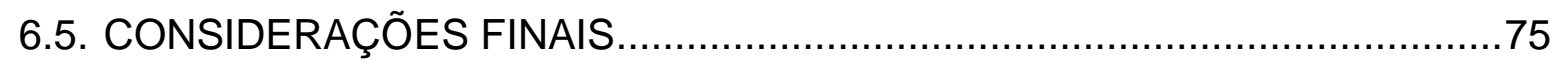

7. CONCLUSÕES E RECOMENDAÇÕES …....................................................77

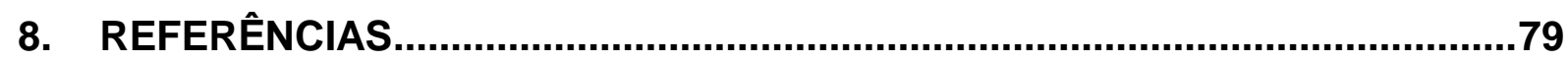

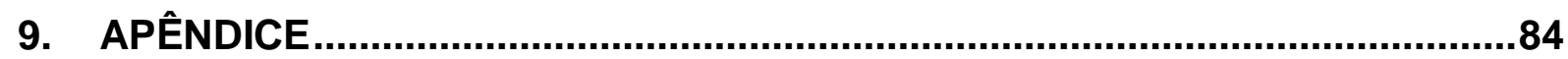

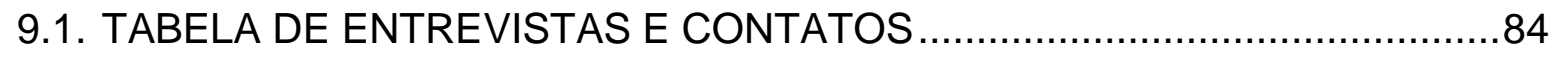

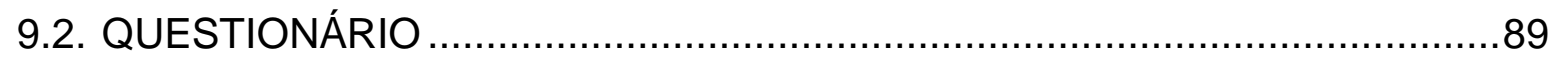

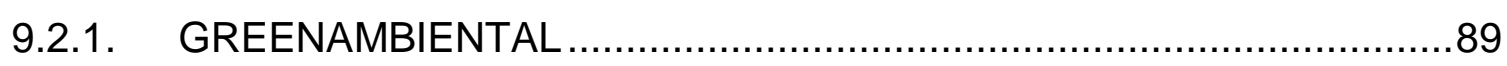

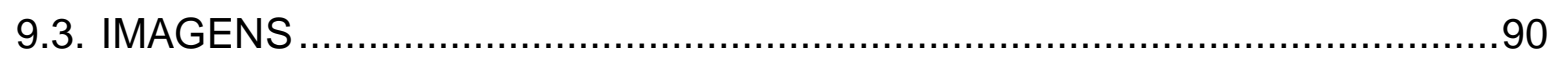

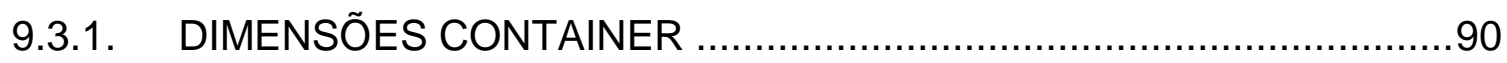

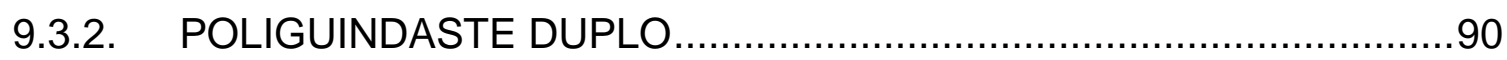

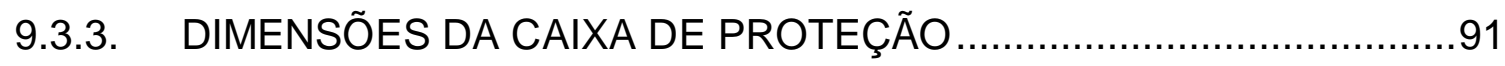

9.3.4. DIMENSÕES TAMPA DA CAIXA DE PROTEÇÃO ………................

9.3.5. FLUXOGRAMAS DAS SIMULAÇÕES DA PROPOSTA .....................92 


\section{INTRODUÇÃO}

\subsection{CONTEXTUALIZAÇÃO}

A geração de resíduos sólidos urbanos é um problema ambiental de abrangência mundial, à medida que a população cresce, a geração de resíduos aumenta proporcionalmente. A destinação inadequada é fator agravante à problemática, pela potencialidade de contaminação do solo, das águas e do ar.

Segundo pesquisa realizada pelo Sistema Nacional de Informações sobre Saneamento (SNIS), 63\% do total de resíduos sólidos gerados são enviados para aterros sanitários e 17,8\% são descartados de forma inadequada em lixões e aterros controlados. Porém, muitos resíduos recicláveis são enviados a aterros, cerca de $5,4 \%$ da massa total de resíduos potencialmente recuperáveis é reciclada. (BRASIL, 2019)

Existem formas vantajosas e menos danosas ao meio ambiente para destinação dos resíduos urbanos, a depender do tipo de resíduo. Os resíduos recicláveis, por exemplo, devem receber tratamento diferenciado, pois podem ser reutilizados na fabricação de novos produtos. A reciclagem é benéfica em diversos aspectos, pois reduz o volume de resíduos destinados aos aterros e lixões, gera empregos e conscientiza a população para questões ambientais. Destinar materiais recicláveis para aterros ou lixões a céu aberto é um desperdício de matéria prima e energia, pois foram gastos recursos ambientais e econômicos para produção desses materiais.

O foco deste trabalho são os resíduos de embalagens de vidro, material reciclável e pouco danoso ao meio ambiente, porém possui características que dificultam o retorno deste resíduo ao ciclo de produtivo. Por exemplo, é um material de baixo valor comercial no mercado de recicláveis, é de difícil manipulação, em consequência dos acidentes de trabalho, é insuficiente a quantidade de unidades fabris instaladas no Brasil que possam absorver os resíduos de vidro, entre outras.

A tecnologia é um forte aliado à reciclagem nos dias atuais, diversas soluções são desenvolvidas tendo em vista aumentar os índices de reciclagem. Algumas contribuições para a reciclagem são os separadores automatizados de resíduos e as soluções em software como aplicativos para celular. Um exemplo é o aplicativo "Cataki" (CATAKI, 2014) que conecta o usuário que deseja se desfazer de resíduos e direciona os catadores cadastrados no aplicativo para coleta. Muitas são as soluções 
inovadoras que contribuem consideravelmente para uma relação amigável entre o homem e o meio ambiente.

Diante do exposto e a partir de uma análise das relações existentes entre os atores da cadeia de reciclagem dos resíduos de embalagem de vidro no Distrito Federal (DF), foi proposta uma solução eletrônica para ser aplicada na empresa Green Ambiental, que tem por objetivo realizar o monitoramento do nível dos resíduos em 10 contêineres distribuídos pelo DF para que a coleta dos resíduos de vidro possa ser otimizada e o fluxo de resíduos de embalagens de vidro para a reciclagem aumente. Este trabalho se propõe a elaborar um sistema de telemetria que auxilie na coleta dos resíduos de embalagens de vidro no Distrito Federal.

\subsection{JUSTIFICATIVA}

A produção física de embalagens de vidro em dezembro de 2018 foi 5,2\% maior em comparação ao mesmo período de 2017 (IBGE, 2018). Fato justificado pela crescente tendência da utilização de embalagens recicláveis, nessas incluídas as de vidro, por países em desenvolvimento como o Brasil (CAPELINE, 2007).

Apesar dos resíduos de embalagens de vidro possuírem alta capacidade de reciclagem, a maioria é descartada em locais inapropriados como os lixões a céu aberto, aterros controlados ou aterros sanitários, cerca de $94,6 \%$ dos resíduos secos gerados no Brasil não é reciclado (BRASIL, 2019). Os resíduos de vidro possuem elevados tempos de degradação na natureza, se não reciclados ficaram imobilizados por muito tempo, mesmo que tenham sido descartados em aterro sanitário.

Os resíduos de vidro foram considerados rejeitos, e devem ser enviados para o aterro sanitário, pois segundo presidente da autarquia responsável pelos Serviços de limpeza urbana do Distrito Federal, Katia Campus, em entrevista no ano de 2018, os responsáveis legais pelos resíduos não realizaram nenhuma ação para que o problema seja solucionado, além da impossibilidade por parte do setor público de assumir responsabilidades do setor privado. Dessa forma os resíduos de vidro de origem domiciliar, coletados no Distrito federal, são considerados resíduos indiferenciados e atualmente são dispostos no aterro sanitário de Brasília.

Atualmente não existem empresas que possam reciclar os resíduos de vidro gerados no Distrito Federal e regiões periféricas, ou fabricas de embalagens de vidro que possam se beneficiar dos resíduos de embalagens de vidro, no seu processo 
produtivo. As empresas do setor vidreiro no Brasil estão localizadas próximas às regiões onde geralmente são extraídas as matérias primas, região sudeste do Brasil. Segundo o diretor da empresa Green Ambiental, Siqueira Filho, existe uma grande dificuldade em enviar o material para a região sudeste do Brasil, pelo alto custo do transporte de Brasília para São Paulo.

Em algumas localidades o preço de mercado dos resíduos de embalagem de vidro não gera viabilidade econômica para que os resíduos possam ser beneficiados e reciclados, pois o custo do manuseio e transporte é superior ao lucro obtido pela comercialização do material. Segundo entrevista ao Cleuzimar Andrade, diretor da Cooperativa Recicle a Vida em Ceilândia, o lucro nas operações comerciais dos resíduos de vidro é baixo para o DF, dessa forma os resíduos de vidro são pouco atrativos para sucateiros e pequenas empresas que trabalham com a coleta, manipulação e comercialização de resíduos recicláveis.

Outro fator que contribui positivamente para o aumento da reciclagem dos resíduos de embalagem de vidro no Distrito Federal, foi a entrada em vigor no ano de 2018 da lei $n=5.610 / 16$, onde os comerciantes do DF devem arcar com os gastos para destinar corretamente os resíduos gerados, caso produzam mais de $120 \mathrm{~L}$ de resíduos indiferenciados por dia (BRASIL, 2016). Como os resíduos e embalagens de vidro são considerados resíduos indiferenciados pelo Serviço de Limpeza Urbana (SLU) do Distrito federal, estes contribuem consideravelmente para o volume de resíduos produzidos pelos estabelecimentos, e acabam por gerar despesas adicionais aos comerciantes locais.

\subsection{OBJETIVOS}

\subsubsection{OBJETIVO GERAL}

Desenvolver equipamento eletrônico que auxilie a coleta de resíduos de embalagem de vidro no Distrito Federal, por meio do monitoramento do nível desses resíduos em contêineres, aliado a um sistema web para monitoramento.

\subsubsection{OBJETIVOS ESPECÍFICOS}

Objetivo 1: Elaborar simulação computacional a respeito da possível economia gerada pelo sistema.

Objetivo 2: Elaborar o projeto de construção do protótipo eletrônico.

Objetivo 3: Confeccionar o protótipo 
Objetivo 4: Validar o protótipo por meio de testes em software e hardware.

\subsection{METODOLOGIA}

Esta pesquisa é caracterizada como aplicada, pois utiliza a informação disponível a respeito de determinado tema para desenvolver novas tecnologias ou métodos que tenham potencial de transformação da sociedade (GIL, 2008). Também possui caráter descritivo na execução do objetivo geral, pois apresenta ao leitor um cenário ao qual o objeto de estudo está inserido. Os resultados da pesquisa são apresentados de forma qualitativa obtidos a partir do resultado de testes experimentais para validação.

Para cumprir os objetivos propostos, foi realizada a caracterização da cadeia produtiva dos resíduos de vidro no Brasil e no Distrito Federal, utiliza-se para tanto fluxos produtivos originados de levantamento de dados primários por meio de entrevistas com atores da cadeia. Para obter tais dados e informações foram necessárias: consulta a relatórios públicos, entrevistas às autoridades públicas responsáveis por resíduos urbanos, às cooperativas de catadores, à empresas recicladoras e empresas fabricantes de embalagens.

O primeiro objetivo específico foi cumprido a partir da coleta de dados primário com os responsáveis administrativos da empresa GreenAmbiental, para realização da modelagem da simulação e determinação da forma de trabalho da empresa.

No segundo objetivo buscou-se determinar os requisitos básicos do sistema, e determinar todos os elementos fundamentais para construção do protótipo. Além da determinação de quais os componentes eletrônicos seriam selecionados para construção do protótipo. Este objetivo será executado por meio de pesquisa aos equipamentos existentes no mercado além de consulta a bibliografia e referencial acadêmico, de maneira a conciliar as limitações financeiras e a funcionalidade da proposta.

No terceiro objetivo específico, foi realizada a construção física do dispositivo, com todos os seus elementos, reunidos e conectados por meio de uma placa de circuito impresso. Utilizou-se o software Catia da empresa DataSystem para elaboração de desenho em 3D e software Proteus Design Suite da empresa Labcenter Electronics Ltd dedicado a simulações e confecção da placa de circuito impresso. 
Para alcançar o quarto objetivo específico, serão elaboradas simulações computacionais em software especifico e testes em bancada com os componentes do sistema, para validar seu funcionamento. 


\section{RESÍDUOS DE EMBALAGEM DE VIDRO NO BRASIL}

Nesta sessão serão apresentadas as principais características das embalagens de vidro, a contribuição de alguns atores da cadeia produtiva deste resíduo, o beneficiamento, a reciclagem e os instrumentos legais relacionados a temática dos resíduos de vidro no Brasil.

\subsection{A EMBALAGEM DE VIDRO}

O vidro é um material amorfo, isto é, não possui estrutura atômica regular, deriva de elementos químicos minerais e apresenta uma composição química homogênea. É formado principalmente por óxidos metálicos de silício, sódio e calcário. Os principais insumos minerais utilizados para fabricação do vidro são: areia quartzítica, calcário, carbonato de sódio e alumina. Em temperatura ambiente os vidros se comportam como um material sólido, porém sua estrutura não sofre cristalização, como acontece em líquidos super-resfriados. (CALLISTER e RETHWISH, 2009)

\subsection{PRODUÇÃO DE RESÍDUOS}

O estudo realizado pela empresa Serenco (serviços de engenharia consultiva) para elaboração do plano de gerenciamento de resíduos sólidos distrital, estimou a gravimetria dos resíduos sólidos domiciliares no Distrito federal (Figura 1) a partir de amostras de resíduos sólidos de 28 regiões administrativas no ano 2016. (GDF, 2018)

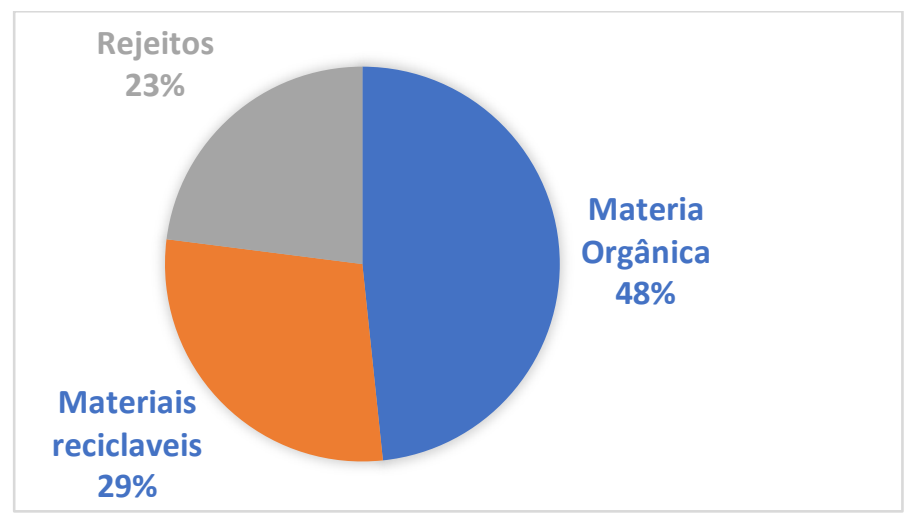

Figura 1. Gravimetria dos resíduos domiciliares do Distrito Federal Fonte: (GDF, 2018)

Ainda sobre a composição gravimétrica dos resíduos recicláveis coletados pelos serviços de coleta convencional e seletiva coleta seletiva a pesquisa da Serenco 
mostra que as embalagens de vidro representam 2,51\% dos resíduos coletados nesses sistemas. (GDF, 2018)

Ao considerar o volume de 2753 toneladas de resíduos domiciliares coletados pelo SLU por dia em média, no primeiro semestre de 2017 (coleta convencional e coleta seletiva), e de acordo com a estimativa do PDGIRS no ano de 2017 e a porcentagem de embalagens de vidro presente nos resíduos domiciliares de 2,51\%, é possível estimar que foram coletados, em média, um volume aproximado de 69,37 toneladas de resíduos de embalagens de vidro por dia no DF durante o primeiro semestre de 2017. (GDF, 2018)

\subsection{BENEFICIAMENTO}

Os resíduos de embalagens de vidro geralmente são descartados após o consumo, acompanhados com outros materiais, como tampas metálicas, canudos plásticos, rótulos de papel ou rolhas de cortiça (Figura 2). Esses resíduos misturados aos resíduos de vidro se tornam contaminantes, pois o processo de reciclagem do vidro necessita que o material esteja livre de impurezas, dessa forma se fazem necessarios processos primários de separação.

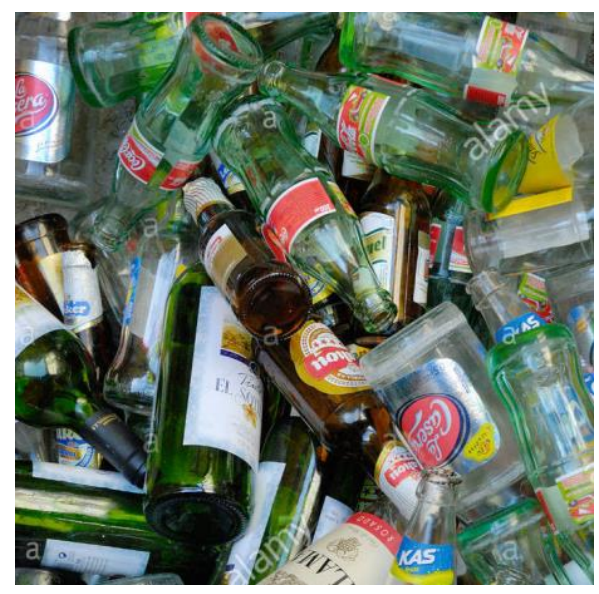

Figura 2. Resíduos misto de embalagem de vidro Fonte: (ALAMY, 2013)

Resíduos plásticos ou metálicos geralmente são compactados por maquinas de prensa com objetivo de reduzir os custos no transporte. Os resíduos de vidro são frágeis e quebradiços, fato que impossibilita a compactação em fardos. Para transportar os resíduos de vidro geralmente são utilizados caminhões do tipo roollonroolloff (Figura 3.a) ou caminhões poliguindaste com caixas do tipo Dempster (Figura 3.b). 


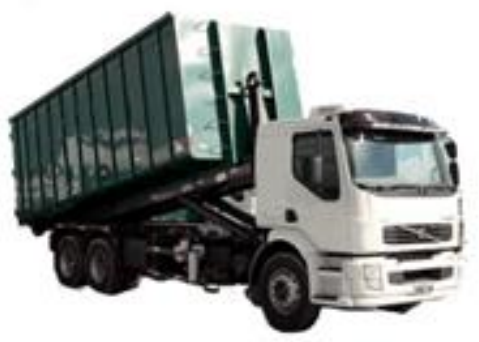

(a)

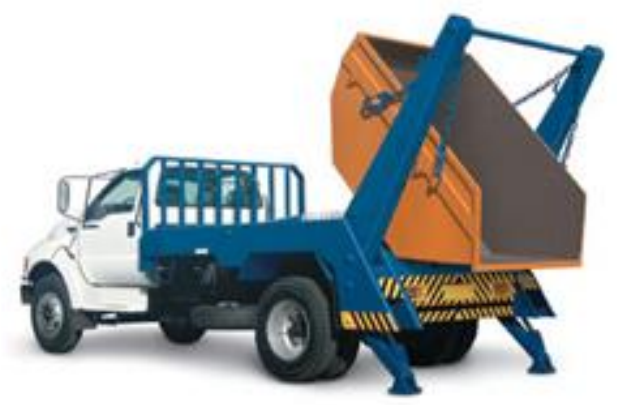

(b)

Figura 3. (a) Caminhão modelo Rollon-rolloff (b) Caminhão Poliguindaste com caixa Dempster Fonte: (a) (VARIEMAQ, 2017) (b) (SOLUÇÕES INDUSTRIAIS , 2014)

Os resíduos de vidro após coletados são armazenados em organizações de catadores e posteriormente são transportados para empresas de beneficiamento, onde são submetidos a processos de limpeza e separação dos contaminantes e trituração.

Um exemplo de empresa beneficiadora é a MASSFIX, localizada no município de Mogi das cruzes no estado de São Paulo. Por meio de aplicação de questionário foi informado pela empresa que são aceitos para o processo de beneficiamento todos os tipos de resíduos de vidro, como espelhos, lâmpadas, embalagens, vidros temperados entre outros e oferece como produto final o vidro triturado e limpo, matéria-prima para as Indústrias Vidreiras e Ceramistas. Os resíduos revalorizados pela MASSFIX atendem às especificações técnicas dos clientes, com relação a cor, granulometria, grau de pureza entre outros.

A empresa RECITOTAL atua no mesmo segmento que a MASSFIX, atua no mercado de reciclagem de resíduos de vidro a mais de 25 anos, e possui duas sedes, uma em Guarulhos (são Paulo) e outra em Pinhais (Paraná). Por meio de aplicação de questionário, foi informado que a empresa recebe vidros planos e embalagens de vidro e realiza o beneficiamento do material de forma manual diferente da MASSFIX que possui uma linha de equipamentos automatizados para realizar a separação dos contaminantes e trituração.

A empresa afirmou que a maneia de tornar os resíduos de vidro mais atrativos seria a redução da quantidade de contaminantes presentes. Afirmou ainda que os contaminantes mais críticos para o processo são as pedras, concreto, porcelanas e cerâmicas em geral. 
Outra empresa que realiza o tratamento dos resíduos de vidro é a fábrica de embalagens de vidro Vidroporto, localizada no estado de São Paulo e se diferencia das anteriormente citadas por possuir um setor dedicado ao tratamento dos resíduos de embalagem de vidro além da fabricação de novas embalagens de vidro.

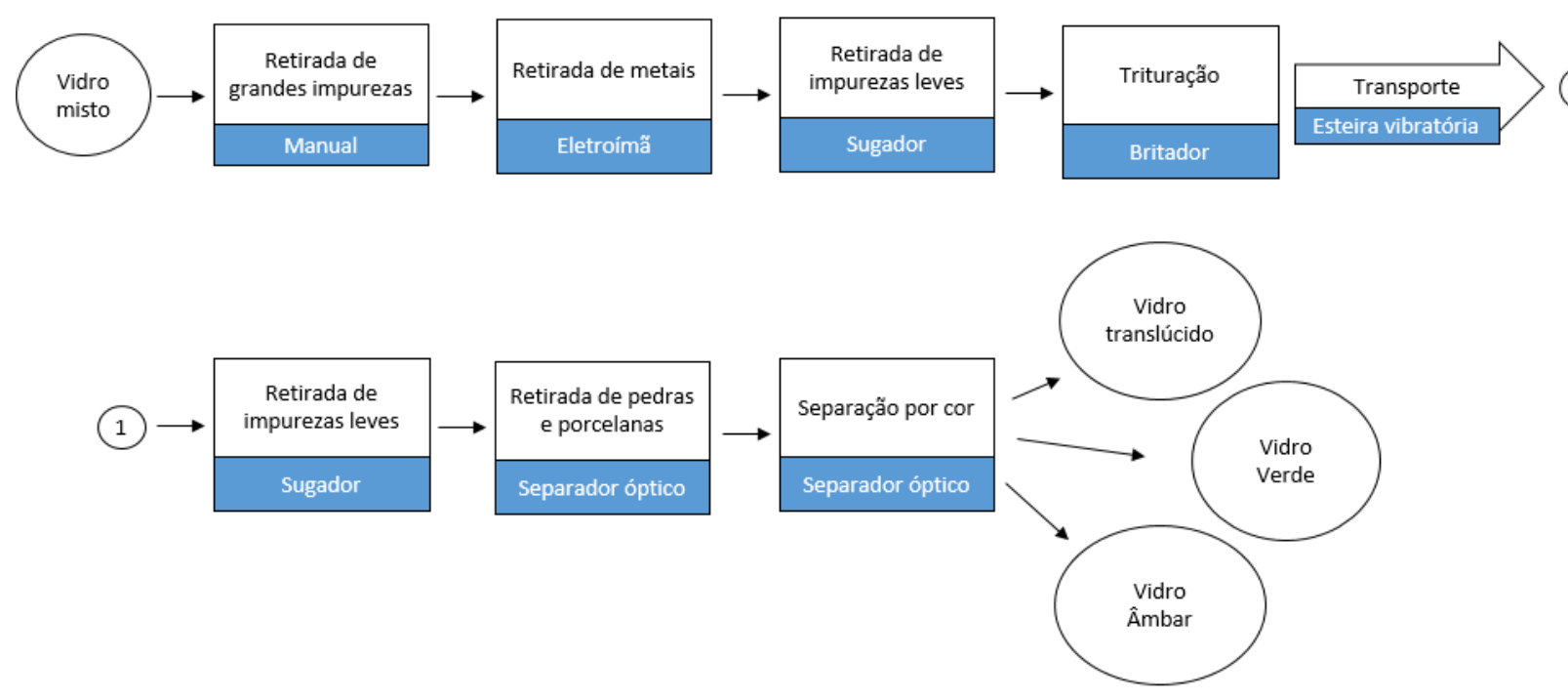

Figura 4. Processo de beneficiamento dos resíduos de vidro na Vidro Porto

Fonte: (VIDROPORTO, 2019)

A denominação vidro misto apresentada na Figura 4 diz respeito aos resíduos de embalagens de vidro em formatos, e cores mistas, com a presença de contaminantes comuns a composição da embalagem (Figura 2). Não é recomendavel misturar resíduos distintos de vidro, pois a reciclagem é realizada com cada tipo de resíduo separadamente, sendo necessário uma composição química homogenea.

As etapas de retirada de contaminantes são fundametais para separar o vidro dos demais materiais e possibilitar sua reciclagem. Elementos metálicos, por exemplo, geram defeitos estéticos e estruturais nos produtos finais de vidros se acidentalmente forem inseridos nos fornos de fusão, bem como os resíduos cerâmicos, como pedras ou fragmentos de porcelana.

O resultado final do processo de beneficiamento na empresa Vidroporto são fragmentos de vidro com granulometria variável separadas por cor e livres de materiais contaminantes. Essas particulas de vidro beneficiado retornam à cadeia produtiva do vidro como matéria prima secundária no processo de fabricação de novas embalagens de vidro. 


\subsection{RECICLAGEM}

Os resíduos de vidro são submetidos a três etapas básicas no processo de reciclagem, a recuperação, etapa que engloba a coleta seletiva e separação na fonte; a revalorização, formada pelos processos de beneficiamento dos materiais, como por exemplo a trituração; e a transformação, que consiste na fabricação de um novo produto a partir dos resíduos antes recuperados e revalorizados. Na Figura 5 as três etapas pelas quais os resíduos podem ser submetidos.

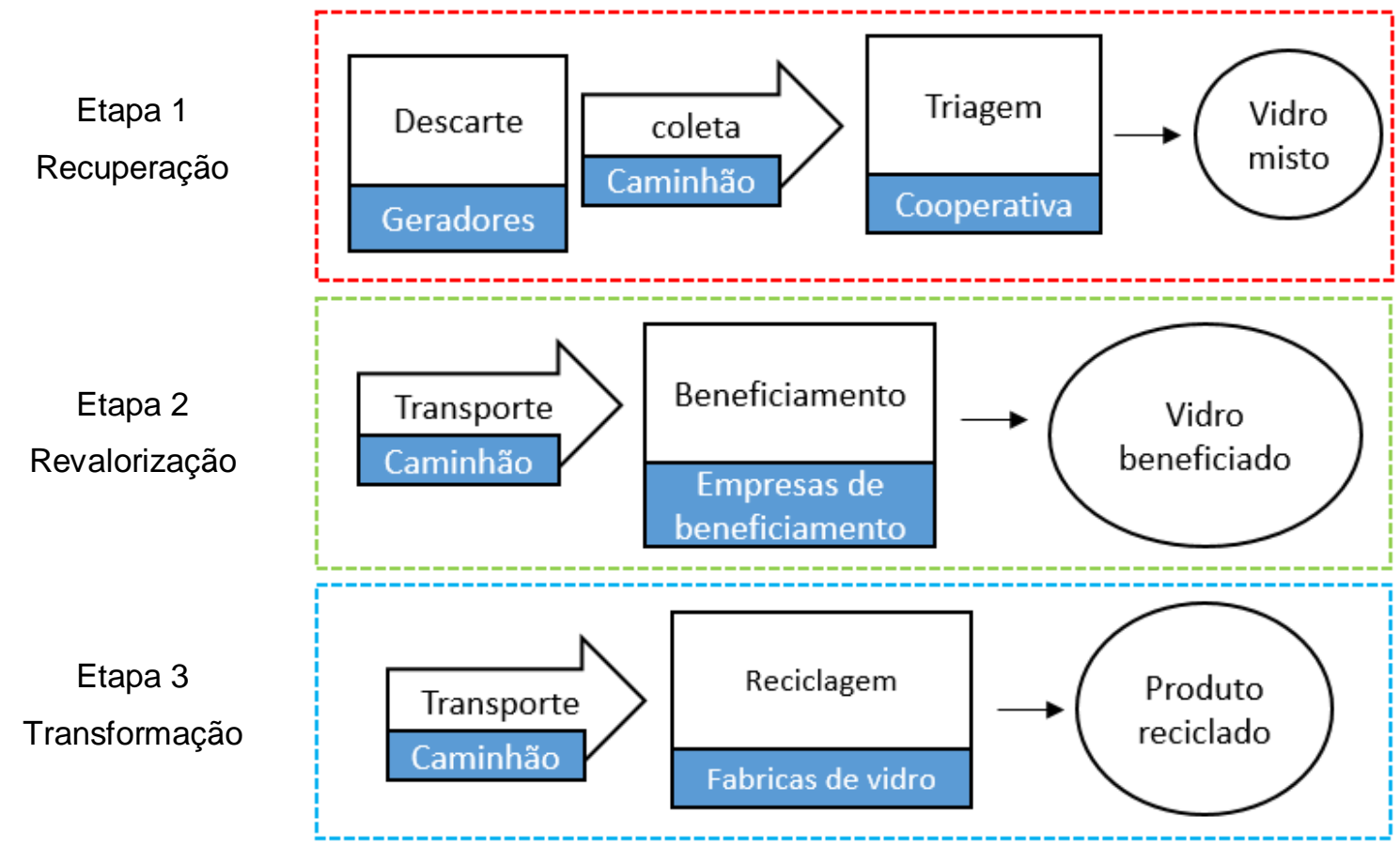

Figura 5. Etapas do processo de recuperação dos resíduos de embalagens de vidro

O vidro é um material $100 \%$ reciclável, ao inserir uma tonelada de vidro beneficiado no forno de fusão pode-se fabricar uma tonelada de vidro fundido, sem perder qualidade (VERALIA, 2010). Essa característica agrega aos produtos fabricados em vidro uma vantagem ambiental significativa em detrimentos aos demais materiais, eles podem ser sempre reciclados.

Vantagens econômicas também são observadas com a utilização de cacos de vidro na produção de novos produtos, é possível reduzir o volume de matéria prima básica utilizada, como por exemplo a areia quartzítica em $60 \%$ e a barrilha em $50 \%$ com a adição de $60 \%$ de cacos de vidro beneficiados no total a ser produzido (Figura 6). Além da economia de $10 \%$ de energia elétrica, $1 \mathrm{~m}^{3}$ de água e 1,2 toneladas de 
matéria prima básica, para cada tonelada de resíduo de vidro for reciclada (IPEIA, 2010).

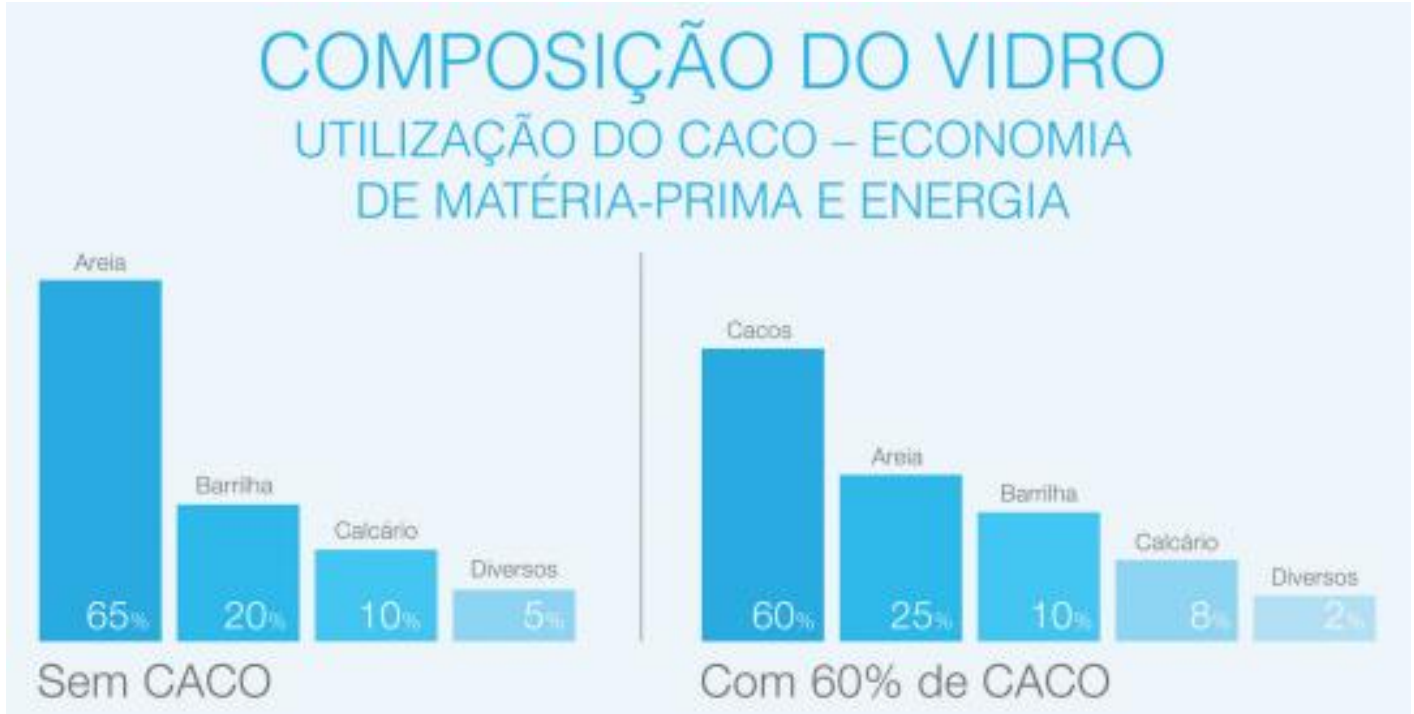

Figura 6. Comparativo de gasto de matéria prima na fabricação do vidro Fonte: (ABIVIDRO, 2015).

O processo de reciclagem só pode ocorrer após os processos de beneficiamento, para que qualquer contaminante possa ser separado dos resíduos de vidro. Então os resíduos de vidro limpos e triturados são submetidos a altas temperaturas para que possam ser novamente conformados. Resíduos de vidros de cores distintas podem ser reciclados juntos, porém o resultado é um vidro de coloração marrom. O ideal é que os resíduos vidros beneficiados estejam totalmente separados por cor e possam ser utilizados no processo de fabricação de sua cor especifica.

\subsection{ATORES DA CADEIA}

Os consumidores são os primeiros responsáveis pela correta destinação dos resíduos gerados, o Artigo 35 da Política Nacional de Resíduos Sólidos (PNRS) determina que é obrigação dos consumidores acondicionar adequadamente e de forma diferenciada os resíduos sólidos gerados e disponibilizar adequadamente os resíduos recicláveis e reutilizáveis. Porém atitudes como a recomendada pela PNRS não são seguidas pela maioria da população e grande parte dos resíduos são dispostos em locais inapropriados. 
Porém a PNRS, no artigo $8^{\circ}$, discorre sobre o incentivo à criação e ao desenvolvimento de organizações de catadores, nesse sentido a lei prioriza os municípios ao acesso aos recursos da União para que "implementem a coleta seletiva com a participação de cooperativas ou outras formas de associação de catadores de materiais reutilizáveis e recicláveis formadas por pessoas físicas de baixa renda" (BRASIL, 2010). Com objetivo de recolocar no ciclo de reciclagem os materiais que estão fora ou foram desviados e incentivar a valorização dos agentes de limpeza pública, pois compreende a importância dessas pessoas na cadeia de reciclagem.

O poder público, no âmbito municipal, tem a responsabilidade de organizar e prestar, diretamente ou sob regime de concessão ou permissão os serviços de limpeza urbana local. Segundo artigo 30 da constituição Federal (BRASIL, 1988), esse serviço é formado pelo conjunto de atividades, infraestruturas e instalações operacionais de coleta, transporte, transbordo, tratamento e destino final do lixo doméstico e do lixo originário da varrição e limpeza de logradouros e vias públicas. (BRASIL, 2007)

Após a coleta é necessário que existam empresa que realizam o armazenamento em grandes quantidades de materiais para que a comercialização seja viável. São microempresários, geralmente autônomos, chamados popularmente de sucateiros, que compram os resíduos dos catadores ou cooperativas de catadores e comercializam para empresas de beneficiamento ou diretamente para fábricas.

As empresas de beneficiamento se responsabilizam por receber os resíduos de vidro sem nenhum tratamento, e comercializar para as fabricas os resíduos de vidro sem impurezas ou contaminantes e triturados em granulometria especifica.

As empresas fabricantes são o elo final da cadeia, são elas que possibilitam que novos produtos sejam fabricados a partir de materiais recicláveis. No caso das embalagens de vidro, os resíduos são tratados e podem ser se tornar uma embalagem nova ou podem ser utilizados para fabricar outros produtos como por exemplo pastilhas de vidro para revestimento, bolas de gude, vasos ornamentais, elementos artesanais de decoração entre outros.

\subsection{INSTRUMENTOS DE REGULAÇÃO}

A geração de resíduos sólidos nos grandes centros urbanos e sua tendência de crescimento incentiva diversos questionamentos a respeito da responsabilidade 
pelos resíduos gerados e qual as melhores formas de gestão e manejo. A partir destes questionamentos foi elaborada a PNRS publicada em dezembro de 2010 e reúne um conjunto de princípios, objetivos, instrumentos, diretrizes, metas e ações com vistas à gestão integrada e ao gerenciamento ambientalmente adequado dos resíduos sólidos. (BRASIL, 2010)

O artigo 8으 da PNRS lei 12.305 enumera todos os instrumentos que devem ser utilizados para auxiliar os gestores públicos, o setor privado e a população no geral a gerenciar e tratar melhor seus resíduos. Entre eles os mais relevantes para essa pesquisa são: os planos de resíduos sólidos; a coleta seletiva e os sistemas de logística reversa que incentivam a responsabilidade compartilhada pelo ciclo de vida dos produtos, tais como a cooperação técnica e financeira entre os setores público e privado para o desenvolvimento de pesquisas de novos produtos, métodos, processos e tecnologias de gestão, reciclagem, reutilização, tratamento de resíduos e disposição final ambientalmente adequada de rejeitos e os acordos setoriais . (BRASIL, 2010)

De acordo com o artigo $3^{\circ}$ da PNRS a logística reversa é um "instrumento de desenvolvimento econômico e social caracterizado por um conjunto de ações, procedimentos e meios destinados a viabilizar a coleta e a restituição dos resíduos sólidos ao setor empresarial, para reaproveitamento, em seu ciclo ou em outros ciclos produtivos, ou outra destinação final ambientalmente adequada" (BRASIL, 2010). No artigo 33 da mesma lei a logística reversa deve ser estruturada e implementada sem a participação do setor público de limpeza urbana, os custos do sistema ficam a cargo dos fabricantes, importadores, distribuidores e comerciantes. (BRASIL, 2010)

As pilhas, baterias, pneus, lâmpadas fluorescentes, óleos lubrificantes e suas embalagens, componentes eletrônicos, são resíduos de responsabilidade dos fabricantes, distribuidores, importadores e comerciantes, esses devem implementar e custear sistemas de logística reversa. Além dos produtos citados a PNRS acrescenta ao grupo as embalagens plásticas, metálicas e de vidro. (BRASIL, 2010)

Para que as ações de logística reversa sejam exigidas é preciso avaliação de viabilidade técnica, bem como o grau e a extensão do impacto econômico, à saúde pública e ao meio ambiente (BRASIL, 2010). As avaliações são executadas por meio de comitê orientador, formado pelo Ministro de Estado do Meio Ambiente, Ministro de Estado da Saúde, Ministro de Estado do Desenvolvimento, Indústria e Comércio Exterior, Ministro de Estado da Agricultura, Pecuária e Abastecimento e Ministro de 
Estado da Fazenda de acordo com a seção III do decreto 7.404 de 2010. (BRASIL, 2010b)

O decreto número 9.177 de 23 de outubro de 2017 estabelece que fabricantes, importadores, distribuidores ou comerciantes que não forem signatários de acordos setoriais ou termos de compromisso firmados com a União são obrigados a implementar e estruturar sistema de logística reversa, consideradas as mesmas obrigações de membros signatários. Em caso de descumprimento das obrigações previstas em lei aplicam-se aos aderentes, aos signatários, e aos não signatários as penalidades previstas na legislação ambiental. (BRASIL, 2017)

Em 2015 foi firmado acordo setorial para implementação de sistemas de logística reversa de embalagens de metal, vidro, plástico e mistas (cartonadas), participaram do acordo a União representada pelo ministério do meio ambiente (MMA) e parte do setor empresarial, intitulada coalisão, formada por 3.709 empresas entre elas fabricantes, importadores, distribuidores e comerciantes como prevê o PNRS. Diversas ações foram realizadas na primeira fase do acordo, como por exemplo a entrega de equipamentos a associações de catadores, ações voltadas a educação ambiental, reformas nas instalações de transbordo de recicláveis, adequação estrutural entre outras ações realizadas em cooperativas e associações de catadores. (SINIR, 2018)

Contudo o Acordo citado onera os cofres públicos segundo a confederação nacional de municípios (CNM) que afirma que 0 acordo não transfere a responsabilidade da coleta das embalagens para o setor privado. As ações existentes no acordo mantem a coleta de resíduos de embalagens a cargo dos sistemas de limpeza pública sem destinar recursos financeiros privados para essas ações, em claro desacordo com a PNRS que afirma que os processos de logística reversa devem ser custeados pelo setor privado (Fabricantes, importadores, distribuidores e comerciantes).

Em obediência ao artigo 14 da política distrital de resíduos sólidos, implementada por meio da Lei 5.418, de 24 de novembro de 2014 (BRASIL, 2014) o governo do Distrito Federal elaborou no ano de 2017 o plano distrital de Gestão integrada dos resíduos sólidos (PDGIRS) inserido no Plano Distrital de Saneamento Básico previsto no artigo 19 da lei federal 11.445 (BRASIL, 2007). O PDGIRS realiza um completo diagnostico setorial com objetivo de atender as exigências legais, 
universalizar a prestação e melhorar a qualidade de serviços prestados, observadas as condições de operacionalização.

Outra importante lei que está diretamente ligada a geração de resíduos é a Lei distrital 5.610 de 16 de fevereiro de 2016, que dispõem sobre a responsabilidade dos grandes geradores de resíduos sólidos não perigosos e não inertes (BRASIL, 2016). Essa determina que os resíduos domiciliares e os que possuem natureza ou composição similares são de responsabilidade do Serviço de Limpeza Urbana (SLU) do Distrito federal e são custeados por taxa de limpeza pública (TLP), para geradores que produzem menos de 120 litros de resíduos sólidos por dia. (BRASIL, 2016)

Os estabelecimentos de "uso não residenciais, incluídos os estabelecimentos comerciais, os públicos e os de prestação de serviço e os terminais rodoviários e aeroportuários" (BRASIL, 2016, p. 1) cuja a composição ou natureza dos resíduos seja similar aos domiciliares e o volume de resíduos gerados por dia seja superior aos 120 litros, estes são considerados grandes geradores. O artigo 4ํㅜ da Lei 5.610 determina que os grandes geradores são integralmente responsáveis pelo gerenciamento ambientalmente adequado dos resíduos sólidos gerados e pelo ônus deles decorrentes. (BRASIL, 2016)

Com objetivo de incentivar a separação dos resíduos recicláveis dos orgânicos e rejeitos, o artigo 5ำ da referida lei determina que o SLU prestará serviço de coleta, transporte e destinação aos resíduos recicláveis sem ônus para o grande gerador se os resíduos estiverem separados no momento da coleta. (BRASIL, 2016)

\subsection{COLETA DOS RESIDUOS DE VIDRO NO DISTRITO FEDERAL}

Segundo a presidente do SLU, Katia Campos, não existem usinas de beneficiamento ou fabricas que possam absorver esses resíduos de vidro no Distrito Federal. A unidade de reciclagem mais próxima do DF está localizada na cidade de Porto Ferreira, empresa Vidro Porto, no estado de São Paulo, localizada a cerca de $800 \mathrm{Km}$ de distância da capital federal.

De acordo com a PNRS os fabricantes, importadores, distribuidores e comerciantes são obrigados a estruturar e implementar sistemas de logística reversa. Por esse motivo o SLU não pode se responsabilizar pelos resíduos de embalagens de vidro coletados no Distrito Federal. Segundo Katia campos a inexistência de uma ação por parte do setor privado, responsável, obriga o SLU a destinar os resíduos de vidro para o aterro sanitário, atitude que gera um desperdício de material reciclável e 
uma redução no tempo de utilização do aterro pois o volume de resíduos disposto no aterro é maior.

Dessa forma os resíduos de vidro gerados no DF são considerados resíduos indiferenciados e devem ser descartados no lixo comum (coleta convencional). Parte da população do Distrito Federal desconhece esse fato e descartam os resíduos de vidro como lixo seco, o sistema de coleta seletiva recolhe o material e leva para as cooperativas de catadores, Segundo Katia esta ação gera um ônus adicional para realizar o transporte e aterramento deste material, pois os resíduos de vidro acumulados nas cooperativas são posteriormente transportados para 0 aterro sanitário de Brasília.

\subsection{DESTINAÇÃO FINAL NO DISTRITO FEDERAL}

Segundo relatório de atividades referente ao primeiro semestre de 2018 elaborado pelo SLU foram coletadas 401.589 toneladas de resíduos de origem domiciliar e de varrição, as fontes principais dos resíduos de embalagem de vidro. Deste quantitativo 392.323 foram aterradas, 34.852 toneladas foram aterradas no aterro controlado do jóquei, atualmente desativado e 358.071 toneladas foram dispostas no aterro sanitário de Brasília, atual destinação para os resíduos de origem domiciliar do Distrito Federal.

No dia 20 de janeiro de 2018 as atividades disposição no aterro controlado do jóquei foram encerradas, atualmente todo o volume de resíduos que antes era disposto no aterro controlado é enviado ao aterro sanitário de Brasília. A mudança do aterro controlado para o aterro sanitário gera benefícios para o meio ambiente e para a população, a partir da mudança os prejuízos causados ao meio ambiente serão reduzidos significativamente (SLU, 2017). Porém os resíduos de vidro são destinados para o aterro sanitário de Brasília juntamente com os resíduos de origem domiciliar e varrição.

Além da coleta convencional o DF dispõe de sistema de coleta seletiva de resíduos, com característica inclusiva, que visa incorporar cooperativas/associações de catadores na gestão dos resíduos sólidos urbanos. Até o fim do ano de 2017 a coleta seletiva era realizada em 17 regiões administrativas (RA), de um total de 31. A partir de 26 de fevereiro de 2018 dez regiões administrativas começaram a ser atendidas com serviços de coleta seletiva, as regiões são: Cruzeiro Velho, Itapoã, 
Lago Norte, Lago Sul, Paranoá, Riacho Fundo I, Riacho Fundo II, São Sebastião, Sobradinho e Varjão. (SLU, 2018)

Os resíduos coletados pela coleta seletiva são submetidos a processo de triagem, enfardamento e são posteriormente comercializados no mercado de recicláveis. Os rejeitos da coleta seletiva são enviados para o aterro sanitário de Brasília, nesses incluídos os resíduos de embalagem de vidro.

\subsection{EMPRESA GREEN AMBIENTAL}

Em meio ao cenário apresentado, a empresa Green Ambiental surge como como uma possível solução para que os resíduos de embalagens de vidro descartados no Distrito Federal posam ser reciclados. A empresa realiza a coleta dos resíduos de embalagem de vidro nos estabelecimentos comerciais e condomínios habitacionais. Após acumular uma quantidade suficiente para viabilizar o transporte realiza o transporte e a comercialização para uma fábrica de embalagens de vidro localizada no estado de São Paulo.

A empresa Green Ambiental é especializada na coleta e transporte de resíduos orgânicos, indiferenciados e recicláveis no Distrito Federal. Iniciou seu funcionamento no início do ano de 2018 e possui parcerias com diversas empresas privadas, dentre elas restaurantes, shoppings e condomínios habitacionais. A empresa é sediada no endereço: ADE Conjunto 5 lote 24 na região administrativa de Águas Claras, Distrito Federal.

A coleta dos resíduos de embalagem de vidro é feita de duas formas. Os resíduos podem ser armazenados em bombonas de 200 litros (Figura 7) e recolhidos por veículo de pequeno porte, com carroceria, ou em locais que o volume de resíduos disponível é maior a empresa recomenda a colocação de caixas Dempster de $5 \mathrm{~m}^{3}$ (Figura 8), a coleta é feita por caminhão poliguindaste duplo articulado modelo Constellation 17.260 (Figura 38), possui capacidade de transporte de dois contêineres simultaneamente.

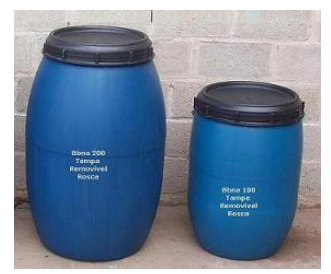

Figura 7. Bombonas plásticas para coleta de resíduos de vidro 


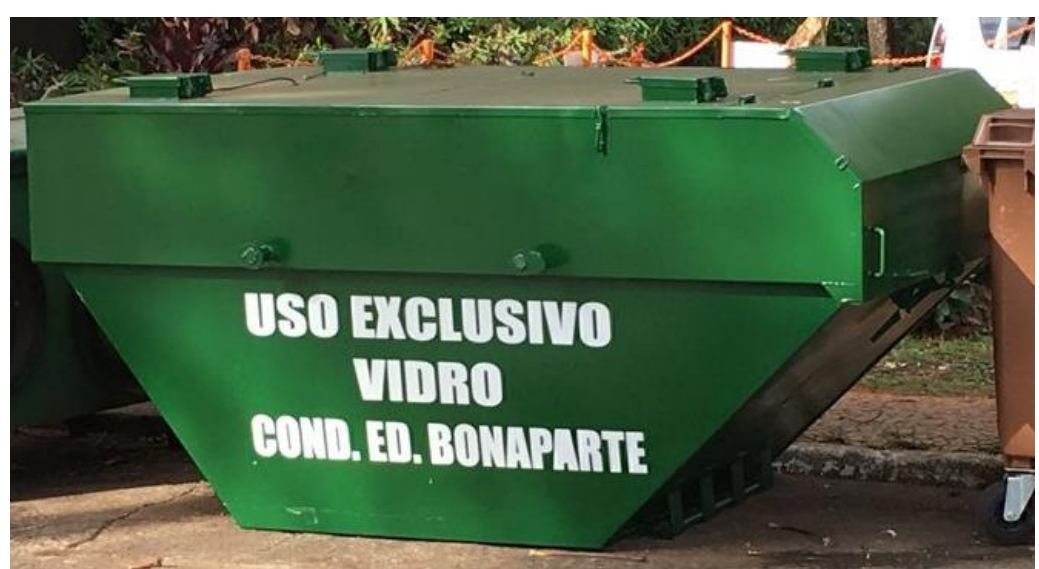

Figura 8. Contêiner utilizado para coleta de resíduos de embalagem de vidro

Atualmente a empresa Green Ambiental possui 10 contêineres instalados no Distrito Federal (Tabela 1). Ao disponibilizar um contêiner em determinada localidade, a empresa vincula o mesmo a um responsável pelo monitoramento do nível dos resíduos no interior das caixas, este pode ser uma pessoa física ou jurídica.

O processo de coleta é iniciado a partir do momento que a empresa é informada que o contêiner está cheio, a primeira ação é enviar um caminhão de coleta que percorre o trajeto da cede em Águas Claras até o referido ponto de coleta, deixa um contêiner vazio no local e recolhe o contêiner cheio, posteriormente o caminhão percorre o caminho do ponto de coleta até a central de armazenamento. Dessa forma a cada coleta a empresa recolhe uma caixa com $5 \mathrm{~m}^{3}$ aproximadamente de resíduos de vidro misto. Na Figura 9 os pontos de coleta plotados em um mapa e a visualização das rotas de transporte dos materiais em azul, as rotas em vermelho soa trajetos onde é proibido o trafego de veículos de grande porte.

As caixas Dempster utilizadas pela empresa possuem quatro aberturas superiores para que as embalagens de vidros possam ser inseridas (Figura 8), e não existem compartimentos internos, dessa forma todo o resíduo de embalagem de vidro depositado é armazenado sem separação por cor ou tipo.

A Tabela 1 foi construída a partir das informações fornecidas pela empresa e por meio da ferramenta online Google Maps. Foram dispostos na Tabela 1 os códigos e as localizações geográficas dos pontos de interesse desta pesquisa. Estas informações serão utilizadas para elaboração de rotas nas estimativas realizas nos próximos capítulos. 
Tabela 1. Localização geográficas dos pontos de coleta

\begin{tabular}{|c|c|c|c|}
\hline Código & Pevs & Latitude & Longitude \\
\hline 1 & ASBAC & -15.817 .357 & -47.870 .577 \\
\hline 2 & Shopping ID & -15.787 .314 & -47.890 .588 \\
\hline 3 & Recicla mais & -15.778 .554 & -47.785 .149 \\
\hline 4 & Ecolimpo & -15.909 .646 & -47.777 .369 \\
\hline 5 & Pontão & -15.825 .605 & -47.873 .461 \\
\hline 6 & Restaurante do lago & -15.849 .296 & -47.904 .630 \\
\hline 7 & Citybank & -15.830 .695 & -47.873 .782 \\
\hline 8 & Pier 21 & -15.819 .338 & -47.874 .311 \\
\hline 9 & Dallas bar & -15.814 .854 & -48.008 .935 \\
\hline 10 & Capital recicláveis & -15.780 .738 & -47.984 .346 \\
\hline 11 & Green Ambiental & -15.875 .321 & -48.018 .575 \\
\hline
\end{tabular}

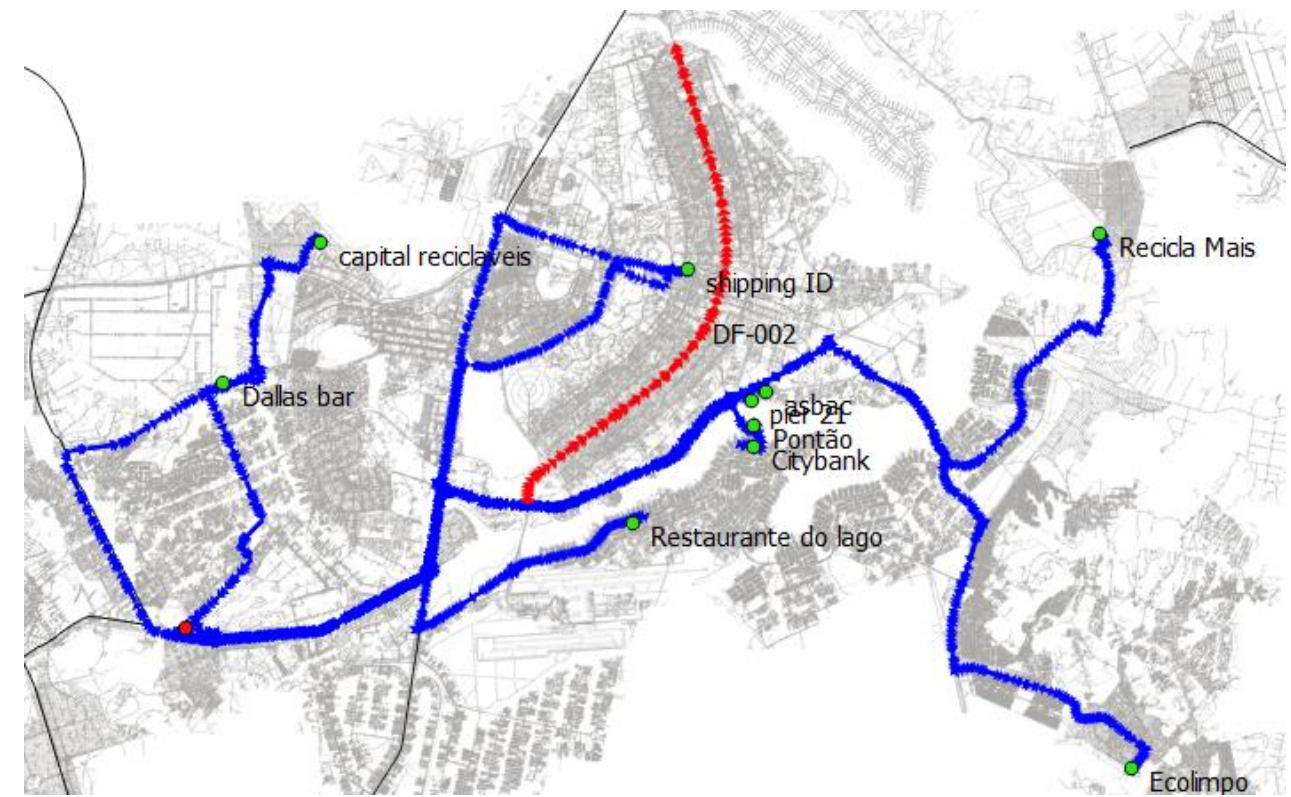

Figura 9. Pontos e rotas de transporte de resíduos da empresa GreenAmbiental

\section{TELEMETRIA}

\subsection{CONCEITO}

O termo "telemetria" tem sua origem do grego telê que significa longe ou ao longe e métron que significa o que mede. (CANO, 1998) O termo significa a medição de dados específicos que geralmente estão em locais remotos, de difícil acesso ou ambientes com condições adversas, como por exemplo temperaturas e pressão 
extremas. Os sistemas de telemetria podem ser divididos em analógicos ou digitais, porém este aspecto não é o mais relevante e sim a tecnologia que será utilizada para transmissão dos dados.

A simples transmissão de dados realizada entre dois pontos é considerada um sistema de telemetria, pois forma um enlace de comunicação e possibilita a troca de informações entre os pontos. Porém a telemetria geralmente é aplicada em sistemas com uma quantidade maior de pontos, com objetivo de coletar um grande número de informação de locais distintos para realizar uma análise geral do sistema.

Como em qualquer sistema de comunicação os enlaces podem ser classificados pela quantidade de pontos de transmissão e recepção, são os enlaces: ponto a ponto, que representam a troca de informação entre dois pontos; pontomultiponto, a informação é transmitida de um transmissor para vários receptores; multiponto-ponto, o envio de informações é feito de vários pontos para um único receptor; e multiponto-multiponto onde a informação pode transitar de vários transmissores para vários receptores. Na maioria das aplicações a telemetria utiliza a forma multiponto-ponto, os transmissores em campo enviam os dados para uma central que os trata, armazena e exibe.

As informações a respeito de determinada grandeza são coletadas por sensores, elemento primário, e os sinais são processados e armazenados para que possam ser posteriormente enviados para o receptor por canais de comunicação que podem ser: cabos; transmissão por rádio frequência; ultrassom; raio laser; fibra ótica entre outros (PATRANABIS, 1999). Após a transmissão o receptor trata os dados para que possam ser exibidos ou armazenadas em banco de dados. Na Figura 10 é possível observar os blocos básicos de um sistema de telemetria.

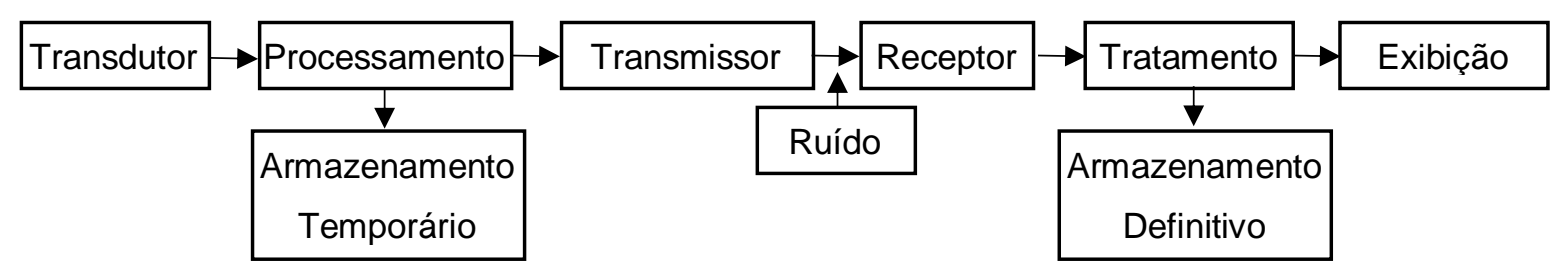

Figura 10. Fluxo de operação de um sistema de telemetria Elaboração do autor

O canal de transmissão é de suma importância para a adequação do sistema de telemetria a forma como as variáveis estão dispostas para coleta. É possível caracterizar os sistemas de telemetria em dois grupos, os sistemas para pequenas distâncias e os 
sistemas para médias e longas distancias. O primeiro utiliza cabos para transmitir as informações sem necessitar grande complexidade no tratamento dos sinais, porém o segundo utiliza técnicas elaboradas de comunicação sem fio, como a modulação por largura de pulso, modulação em fase, modulação por amplitude, modulação em frequência entre outros.

É possível ainda classificar os sistemas de telemetria em moveis ou fixos, a depender das condições das fontes emissoras. Nos sistemas fixos as informações são enviadas sempre da mesma posição geográfica, nos sistemas móveis a transmissão pode acontecer em diversos pontos geográficos, como por exemplos transmissores instalados em um automóvel.

A telemetria tem o objetivo de auxiliar a tomada de decisão e o controle de ações, pois de posse dos dados coletados, os responsáveis pelo sistema em monitoramento podem tomar decisões com maiores chances de sucesso. Dessa forma a telemetria tem se mostrado um forte atrativo a diversas áreas, pois proporciona um acesso rápido e fácil a informações sobre determinado sistema, agrega fidelidade aos dados coletados, proporciona um monitoramento em tempo real, torna possível a geração de relatórios detalhados e reduz custo de operação e manutenção de todo o sistema em monitoramento. (ALVES, 2017)

Os sistemas de telemetria geralmente possuem alarmes para cada variável que é monitorada, ou seja, se os valores aferidos das variáveis de interesse divergirem de uma faixa considerada normal para as características do sistema, a central que realiza o monitoramento será avisada instantemente sobre a situação e pode, à distância, tomar decisões para resolver esse problema, ou mesmo configurar rotinas de controle, para que o sistema se auto regule quando algo anormal aconteça.

Além do monitoramento também é possível o controle, este é chamado de telecomando, neste caso a central de processamento envia comandos para a unidade distante e este executa a solicitação, geralmente é utilizado em complemento ao sistema de telemetria.

As diversas formas de transmissão de dados possibilitam que os sistemas de telemetria estejam em constante avanço. Dessa forma, não existe tecnologia que se possa classificar como ideal, a melhor solução depende da aplicação, de maneira que se faz necessário uma análise que considere a disponibilidade de redes no local de aplicação, a abrangência física do sistema, densidade de pontos de transmissão, se 
existe ou não a necessidade de comandos a distância, entre outros aspectos relevantes a implementação do sistema de telemetria.

\subsection{APLICAÇÕES}

Atualmente a telemetria faz parte do cotidiano do homem moderno e à medida que novas tecnologias são implementadas a telemetria aumenta seu raio de ação. Hoje essa forma de medir pode ser encontrada em ônibus, taxis, veículos de carga, na leitura mensal do consumo de água ou energia elétrica, em residências automatizadas, entre outras aplicações que proporcionam comodidade e praticidade a seus usuários.

Exemplo deste tipo de tecnologia o Projeto de Sustentabilidade Hídrica de Pernanbuco (PSHPE) da Agencia Pernambucana de Águas e Clima (APAC) que instalou e monitorou o nível, ph e salinidade da água em 20 poços. O sistema contou com hidrômetros de telemetria, módulos de comunicação remota GPRS e um sistema central do tipo SCADA (Supervisory Control and Data Acquisition) para supervisão e aquisição dos dados. (AZEVEDO, MACIEL e GAMA, 2019)

Outro exemplo é a aplicação desta tecnologia na agricultura, para integrar conceitos de agricultura de precisão. Muitas são as tecnologias utilizadas para implementação da agricultura de precisão, como por exemplo os veículos aéreos não tripulados (VANT), drones, o sensoriamento remoto, estações de coleta de dados em pontos estratégicos na plantação, o uso de sistemas de informações geográficas (SIG) e o Global Positioning System (GPS). Ao relacionar parâmetros físicos com posições geográficas, torna-se possível mapear com precisão toda área plantada e atuar de forma individualizada nos problemas. A empresa Otmis é um exemplo de empresa fornecedora de serviços de tecnologia no setor Agrícola. (OTMIS, 2019)

Também são aplicados conceitos de telemetria para realização de leitura de consumo de água e energia elétrica, para que a obtenção de dados seja realizada mais rapidamente e com grau de confianção maior. A CAESB, Companhia Saneamento Ambiental do Distrito Federal, é responsável pelo tratamento, distribuição e saneamento do DF, com objetivo de reduzir os desperdícios na rede de distribuição de água, está realizando a instalação de equipamentos de telemetria nos pontos de macromedição do Distrito Federal. A empresa utiliza o equipamento Telelog, desenvolvido pela empresa Ensitec tecnologia, este equipamento se comunica remotamente via GPRS, e envia os dados de pressão da rede para a central 
da companhia, onde funciona um sistema de monitoramento e controle, do tipo SCADA.

A empresa Tecmetra soluções em telemetria utiliza a transmissão por rádio frequência para realizar a leitura de medidores de água, energia e gás em prédios e condomínios com objetivo de reduzir os gastos e tornar o pagamento justo por parte dos moradores que utilizam os serviços. A leitura é realizada a distância, podendo ser realizada por um leiturista percorrendo os andares e corredores do prédio, ou percorrendo ruas nos condomínios. (TECMETRA, 2018)

Conceitos de telemetria também podem ser aplicados na área da saúde. Neste setor a telemetria possibilita o monitoramento de sinais vitais e acompanhamento preciso do estado de saúde dos pacientes. Em alguns casos em que é necessário um rápido socorro, sistemas de telemetria podem evitar que fatalidades aconteçam, pois indicam rapidamente o estado crítico dos pacientes. Um exemplo é a mobilehelp, uma startup norte-americana que utiliza a telemetria para chamados de emergência. Em situações de risco ou emergenciais, o paciente aciona um pequeno botão, que deve estar próximo ao paciente. Automaticamente o responsável pelo paciente recebe 0 alerta e pode prestar socorro imediato. Além do alerta o paciente pode se comunicar com seu cuidador ou enfermeiro por meio do sistema. (MOBILEHELP, 2018)

Atualmente a telemetria está bastante difundida no monitoramento de frotas de veículos, existem diversas empresas que prestam este serviço, estas soluções disponibilizam a visualização em tempo real da posição geográfica de cada veículo da frota, além de coletar dados como a velocidade, rotação do motor, temperatura entre outros aspectos. Todos os dados coletados são utilizados para tomada de decisões por parte da empresa contratante do serviço. São exemplos as empresas: Quatenus, Cobli, routeasy entre outras. Essas empresas usam tecnologia de localização via GPS para registro da localização dos veículos, e como serviço adicional é possível realizar o bloqueio do veículo a distância, tornando-o inoperante.

São diversas as possibilidades de aplicação do conceito de telemetria nos setores empresariais e industriais da sociedade, além de aplicação para comodidade pessoal em atividades cotidianas. A aplicação destes conceitos torna os processos mais robustos e confiáveis reduzindo-se o tempo para execução. 


\subsection{FORMA DE TRANSMISSÃO}

Nesta sessão serão expostas as tecnologias que são geralmente utilizadas para implementação de sistemas de telemetria. São elas a transmissão por microondas, transmissão de dados via satélite, rede de dados GPRS e Wimax.

\subsubsection{TRANSMISSÃO POR MICRO ONDAS}

A transmissão de ondas de rádio terrestre utiliza micro-ondas eletromagnéticas de $30 \mathrm{MHz}$ a $30 \mathrm{GHz}$, e são tecnologias que necessitam de visada direta, ou seja, a linha de visão do emissor e do receptor deve estar desobstruída. Por conta da curvatura da terra as torres de transmissão e recepção do sinal não podem estar a mais de $48 \mathrm{~km}$ de distância uma das outras. Dessa forma as estações são instaladas em série, o sinal é transmitido de uma estação para outra até que a informação consiga chegar ao seu destinatário final. (STAIR e REAYMONDS, 2011)

Para utilizar a faixa do espectro de frequências eletromagnéticas, a transmissão deve seguir normas para que o trafego de dados aconteça sem interferência. As microondas são classificados em três tipos, O VHS (very high frequency), UHF (ultra high frequency) e o SHF (Super high frequency) abaixo suas respectivas faixas de operação e os serviços alocados em cada faixa.

Tabela 2. Classificação do espectro eletromagnético

\begin{tabular}{|c|c|c|}
\hline Classificação & Faixa utilizada & Serviços \\
\hline VHS & $30 \mathrm{MHz}$ à $300 \mathrm{MHz}$ & Radio difusão FM e canais de TV \\
\hline UHF & $300 \mathrm{MHz}$ à $3 \mathrm{GHz}$ & $\begin{array}{c}\text { Canais de TV UHF e de telefonia } \\
\text { celular }\end{array}$ \\
\hline SHF & $3 \mathrm{GHz}$ à $30 \mathrm{GHz}$ & $\begin{array}{c}\text { Transmissão de dados via satélite } \\
\text { (telefonia e dados), TV por assinatura } \\
\text { e frequências para rádio digital. }\end{array}$ \\
\hline
\end{tabular}

Fonte: (CARVALHO e LUIS FERNANDO DA COSTA BADINHAN, 2011)

\subsubsection{TRANSMISSÃO DE DADOS VIA SATÉLITE}

A comunicação via satélite é outra possibilidade de transmissão de dados sem fio, utiliza microondas para envio, porém a comunicação é realizada entre uma estação terrestre e um satélite geoestacionário. Este tipo de transmissão de dados possibilita uma abrangência mundial. $O$ satélite recebe 0 sinal em determinada frequência de uma estação base em terra, o amplifica e retransmite em outra frequência para outra estação terrestre. (STAIR e REAYMONDS, 2011) 
A complexidade de projetos dos satélites e a limitada banda de frequência para o serviço são fatores que aumentam o custo deste serviço, e levam a uma seletividade de aplicações. (PROTZEK e DESCARDECI, 2001)

A necessidade constante de manutenção, nas estações transceptoras terrestres, tem se mostrado como uma barreira para a implementação de sistemas de telemetria utilizando transmissão de dados via satélite.

\subsubsection{REDES DE DADOS GPRS}

A primeira geração de rede de celulares surgiu entre as décadas de sessenta e setenta, utilizava sinais analógicos para o envio de dados, que na época compreendia dados relativos somente a voz. O elevado nível de ruído e a baixa taxa de transmissão incentivaram o surgimento de outras gerações de redes de telefonia como a 2G, 2,5G, 3G entre outras. (RAPPAPORT, 2009)

A partir da geração $2 \mathrm{G}$ foi possível a transmissão de dados por meio da utilização da infraestrutura de telefonia celular, porém o sistema possuía uma capacidade reduzida, cerca de 10Kbps, a partir da implementação do 2,5G e o sistema GSM (global system for mobile communications), mais especificamente pelo serviço GPRS (General packet radio system) a comunicação com a internet possibilitou velocidades de até 171,2 kbps.

O serviço GPRS cria uma rede de pacotes sobre a rede GSM para envio e recepção e dados e apresenta vantagens em comparação aos outros sistemas de comunicação sem fio, como uma rápida conexão, a tarifação é realizada por tráfego de dados, integração com internet e todos os serviços associados, cobertura do serviço em todos os locais onde a cobertura de sinal de telefonia por voz está ativa, entre outras. Essa tecnologia se apresenta como uma ótima solução para os sistemas de telemetria, pois possui uma boa abrangência e uma conexão à internet facilitada. (DILLENBURG, 2004)

\section{PROPOSTA DE OTIMIZAÇÂO}

\subsection{ANÁLISE DO PROBLEMA}

Frente ao cenário atual da cadeia de reciclagem dos resíduos de vidro no Distrito Federal, percebe-se que o principal aspecto que dificulta o retorno dos resíduos de vidro localizados no DF para o início do ciclo produtivo é o fato do custo de mercado dos resíduos de embalagem de vidro ser inferior aos gastos de coleta, 
manipulação e transporte. Aliado a isso está o fato das empresas de reciclagem ou beneficiamento estarem distantes geograficamente dos locais de geração de resíduos, neste caso o Distrito Federal.

Uma maneira de reduzir os custos com transporte seria a possibilidade de utilizar técnicas de economia em escala, que consiste na redução dos custos do transporte de materiais por meio do aumento do volume transportado. A economia nos custos acontece por que as despesas fixas são distribuídas por unidade de peso, dessa forma quanto maior a carga, menores são os custos totais por unidade de peso no transporte de cargas. (BOWERSOX, 2011)

Com objetivo de utilizar a técnica de economia em escala, a Green Ambiental utiliza um trator retroescavadeira para triturar os resíduos, isto é realizado atualmente no pátio da empresa. Porém não realiza um processo de seleção do material para retirada de contaminantes. Fato que pode prejudicar a qualidade do material coletado, pois com relação aos contaminantes as empresas entrevistadas MASSFIX e RECITOTAL afirmaram que pedras ou fragmentos de porcelana se triturados em meio aos resíduos de vidro inviabilizam a separação, e consequentemente a reciclagem para fabricação de novos produtos. As duas empresas recomendaram que a trituração deve ser realizada após um pré-seleção dos resíduos.

A empresas que estão no início da cadeia de retorno dos resíduos de vidro, não se preocupam demasiadamente com os contaminantes, por existir um alto grau de tecnologia embarcada no final do processo. Mesmo que os resíduos sejam transportados, com canudos plásticos, rótulos, tampas metálicas ou plásticas, todos esses contaminantes são separados dos resíduos de vidro, por processos de sucção, atração magnética e por separação ótica.

Outra forma de agregar valor aos resíduos de embalagens de vidro seria a separação por cores como informado por meio de questionários as empresas MASSFIX e RECITOTAL. Porém a empresa Green Ambiental não possui pessoal capacitado para a separação do material por cor ou retirada de contaminantes.

Segundo a PNRS é dever do setor privado, fabricantes, importadores, distribuidores e comerciantes arcar com os gastos referentes aos custos de coleta, manejo e correta destinação das embalagens de vidro, porém não existem ações no DF, por parte do setor privado, que viabilizem o envio das embalagens de vidro para serem recicladas. 
Com intenção de otimizar a cadeia de reciclagem de vidro no Distrito Federal, optou-se pela elaboração e construção de um sistema de telemetria que possibilite reduzir o custo de coleta de resíduos de vidro da empresa Green Ambiental no Distrito Federal. O sistema possibilitará que a eficiência da coleta aumente, pois serão recolhidos dois contêineres por trajeto de coleta, pois está é a capacidade máxima do caminhão utilizado pela empresa. Com objetivo de reduzir os custos de coleta, manipulação e transporte.

\subsection{OTIMIZAÇÃO}

Atualmente a empresa Green Ambiental responsabiliza uma pessoa próxima ao local de disposição do contêiner e este se encarrega de entrar em contato com a empresa sempre que perceber o container cheio, para que a coleta seja realizada. Desta forma geralmente os caminhões de transportam um contêiner por viagem, salvo em ocasiões em que dois contêineres ficam cheios em um curto período de tempo, até um dia.

A proposta aqui apresentada consiste em mapear os níveis de todos os contêineres disponíveis e permitir o armazenamento das informações em um sistema web, que possa analisar a partir da indicação de enchimento do primeiro contêiner qual seria o próximo contêiner que deve ser coletado de maneira que a eficiência da coleta seja maior, ou seja, a opção em que a relação volume coletado por quilômetro percorrido seja melhor que a forma atualmente utilizada.

O sistema de telemetria se baseia nas informações dos níveis de cada contêiner, e armazena as informações em uma plataforma web. De forma que seja possível que o usuário acompanhe os históricos de coleta e a situação atual de cada ponto. O sistema utilizará os dados de distâncias entre os pontos de interesse do sistema e o nível de cada contêiner para verificar dentre todas as possíveis rotas qual apresenta a melhor eficiência.

\subsection{SIMULAÇÃO DA PROPOSTA DE OPTIMIZAÇÃO}

Para estimar se a proposta deste trabalho poderia gerar benefícios econômicos para empresa, foram elaboradas duas simulações em computador. Uma simulação realizou o enchimento dos contêineres da forma como a empresa GreenAmbiental trabalha e a outra simulou a forma de trabalho apresentada neste trabalho. As simulações se basearam em informações obtidas por aplicação de questionários a 
empresa GreenAmbiental e entrevistas ao Vitor Sirqueira, gerente administrativo da empresa.

Dois softwares em linguagem de programação $C$ foram desenvolvidos para as simulações, estes realizavam o preenchimento automático de quatro contêineres, e determinavam quais contêineres deviam ser coletados a depender da forma de operação. Os softwares funcionam de forma cíclica e acrescentam uma quantidade fixa de resíduos nos contêineres a cada ciclo de um dia. As simulações foram elaboradas para 60 dias e não consideram as variações no enchimento dos contêineres, como por exemplo aos finais de semana em que o consumo de embalagens de vidro é geralmente maior. No item 9.3.5 estão disponíveis os fluxogramas contendo a lógica de funcionamento das duas simulações.

Os contêineres escolhidos para simulação estão localizados no Shopping Pier 21, Dallas Bar, Pontão Lago Sul e Shopping ID. Esses pontos foram escolhidos pois apresentam, segundo Vitor, tempos de enchimento intermediários de cerca de 5 a 8 dias. Vitor ainda afirmou em entrevista que esses valores são variáveis, pois existem pontos instalados em cooperativas que ficam cheios em cerca de 3 dias e pontos instalados em condomínios habitacionais que ficam cheios em 15 dias.

Para que os softwares sejam capazes de decidir entre quais rotas são melhores é necessário inserir no programa a matriz de distâncias (Tabela 3) com todos os pontos de interesse desta pesquisa. Com a utilização da ferramenta de geração de rotas entre pontos da empresa Google, foi possível determinar a distância entre os pontos, obedecendo a restrição de vias onde o trafego de veículos de grande porte é proibido. Além dos pontos de coleta foi adicionado o ponto de armazenamento dos resíduos, a sede da empresa Green Ambiental, Local de partida e chegada dos veículos de transporte.

Os pontos P1, P2, P3 e P4 representam os contêineres instalados no Shopping Pier 21, Dallas Bar, Pontão Lago Sul, Shopping ID, respectivamente. A letra G representa a sede da empresa.

Tabela 3. Matriz de distância entre os pontos de interesse

\begin{tabular}{|c|c|c|c|c|c|}
\hline Km & P1 & P2 & P3 & P4 & G \\
\hline p1 & 0,00 & 19,00 & 3,30 & 6,70 & 20,60 \\
\hline p2 & 19,50 & 0,00 & 20,50 & 16,20 & 12,40 \\
\hline p3 & 1,50 & 19,10 & 0,00 & 6,60 & 20,80 \\
\hline p4 & 5,80 & 17,20 & 6,70 & 0,00 & 22,90 \\
\hline G & 19,70 & 13,80 & 20,80 & 23,80 & 0,00 \\
\hline
\end{tabular}


Com base nas respostas obtidas por meio de questionário, ao gerente administrativo da empresa Green Ambiental, Vitor, foram determinados os valores de 5, 6, 7 e 8 dias para os contêineres, P3, P1, P2 e P4 respectivamente.

O software que opera da forma tradicional realiza o enchimento dos contêineres a cada ciclo, de acordo com valores pré-determinados, 5, 6, 7 e 8 dias, e a cada enchimento de um ou mais contêineres o sistema indica quais devem ser coletados. Após a coleta aguarda até que outro container esteja cheio para realizar uma nova coleta.

O software que opera de forma otimizada realiza as mesmas operações iniciais que a forma tradicional, porém ao identificar que um contêiner está cheio, realiza em seguida sucessivos cálculos com todas as possibilidades de rotas de retorno, em busca da melhor relação $\mathrm{Km}$ percorridos por volume de resíduo coletado. Ao final da busca indica ao usuário o segundo ponto de coleta. Neste caso sempre serão coletados dois contêineres por trajeto, de maneira a aproveitar melhor a capacidade dos caminhões poliguindaste duplo que a empresa possui. Na sessão apêndices, item 9.3.5 são apresentados fluxogramas contendo a lógica de programação das duas simulações.

A partir das simulações foi possível analisar os dias em que os contêineres em estudo ficariam cheios, o volume aproximado de resíduos supostamente coletados e as distâncias percorridas totais em cada forma de trabalho.

Para a forma tradicional (Tabela 4), foi estimado um volume total coletado de $185 \mathrm{~m}^{3}$ de resíduos de vidro para 1199,2 Km percorridos em 60 dias. Neste período o sistema tradicional apresentou uma eficiência de $0,15427 \mathrm{~m}^{3} / \mathrm{km}$.

A forma tradicional obteve um volume total coletado foi de $185 \mathrm{~m}^{3}$ de resíduos de vidro para uma distância percorrida de 1199,2 km. A forma otimizada obteve o volume total coletado foi de $184,9 \mathrm{~m}^{3}$ de resíduos de vidro para uma distância percorrida de $946,6 \mathrm{~km}$ nos 60 dias analisados. 
Tabela 4. Simulação da proposta nas duas formas de trabalho

\begin{tabular}{|c|c|c|c|c|c|c|c|c|c|c|}
\hline \multicolumn{11}{|c|}{ Volume coletado em 60 dias $\left[\mathrm{m}^{3}\right]$} \\
\hline \multicolumn{6}{|c|}{ Forma tradicional } & \multicolumn{5}{|c|}{ Forma otimizada } \\
\hline Dias & P1 & P2 & P3 & P4 & $\begin{array}{l}\text { Distância } \\
\text { percorrida }\end{array}$ & P1 & P2 & P3 & P4 & $\begin{array}{l}\text { Distância } \\
\text { percorrida }\end{array}$ \\
\hline 50 & & & 5,00 & & 41,6 & 4,16 & & 5,00 & & 42,9 \\
\hline 6o & 5,00 & & & & 40,3 & & & & & 0,0 \\
\hline 70 & & 5,00 & & & 26,2 & & 5,00 & & 4,37 & 52,9 \\
\hline 8은 & & & & 5,00 & 46,7 & & & & & 0,0 \\
\hline 10 은 & & & 5,00 & & 41,6 & 4,16 & & 5,00 & & 42,9 \\
\hline $12^{\circ}$ & 5,00 & & & & 40,3 & & & & & 0,0 \\
\hline 140 & & 5,00 & & & 26,2 & & 5,00 & & 4,37 & 52,9 \\
\hline 150 & & & 5,00 & & 41,6 & 4,16 & & 5,00 & & 42,9 \\
\hline 160 & & & & 5,00 & 46,7 & & & & & 0,0 \\
\hline 180 & 5,00 & & & & 40,3 & & & & & 0,0 \\
\hline 20 은 & & & 5,00 & & 41,6 & 4,16 & & 5,00 & & 42,9 \\
\hline 210 & & 5,00 & & & 26,2 & & & & & 0,0 \\
\hline 240 & 5,00 & & & 5,00 & 49,3 & & 5,00 & & 4,37 & 52,9 \\
\hline $25^{\circ}$ & & & 5,00 & & 41,6 & 4,16 & & 5,00 & & 42,9 \\
\hline 280 & & 5,00 & & & 26,2 & & 5,00 & & 4,37 & 52,9 \\
\hline 300 & 5,00 & & 5,00 & & 42,9 & 4,16 & & 5,00 & & 42,9 \\
\hline $32^{\circ}$ & & & & 5,00 & 46,7 & & & & & 0,0 \\
\hline 350 & & 5,00 & 5,00 & & 55,1 & & 5,00 & 5,00 & & 55,1 \\
\hline 360 & 5,00 & & & & 40,3 & 5,00 & & & 5,00 & 49,3 \\
\hline $40 \circ$ & & & 5,00 & 5,00 & 50,3 & 3,33 & & 5,00 & & 42,9 \\
\hline $42^{\circ}$ & 5,00 & 5,00 & & & 51,1 & & 5,00 & & 3,75 & 52,9 \\
\hline 450 & & & 5,00 & & 41,6 & 4,16 & & 5,00 & & 42,9 \\
\hline 48 & 5,00 & & & 5,00 & 49,3 & & & & & 0,0 \\
\hline 490 & & 5,00 & & & 26,2 & & 5,00 & & 4,37 & 52,9 \\
\hline 500 & & & 5,00 & & 41,6 & 4,16 & & 5,00 & & 42,9 \\
\hline $54^{\circ}$ & 5,00 & & & & 40,3 & & & & & 0,0 \\
\hline 550 & & & 5,00 & & 41,6 & 4,16 & & 5,00 & & 42,9 \\
\hline 560 & & 5,00 & & 5,00 & 52,9 & & 5,00 & & 4,37 & 52,9 \\
\hline $60 \circ$ & 5,00 & & 5,00 & & 42,9 & 4,16 & & 5,00 & & 42,9 \\
\hline Totais & 50,00 & 40,00 & 60,00 & 35,00 & 1199,20 & 49,93 & 40,00 & 60,00 & 34,97 & 946,60 \\
\hline
\end{tabular}

É possível verificar que a forma tradicional apresentou uma eficiência estimada de $0,1542 \mathrm{~m}^{3} / \mathrm{km}$, em contrapartida a forma otimizada apresentou uma eficiência de 0,1953 m³/km, uma melhora de $26,61 \%$. A quantidade de resíduos coletados, não se diferiu significativamente nas propostas pois não houve diferença entre a quantidade 
de resíduos dispostos para coleta, porém a distância total percorrida foi reduzida em $252,6 \mathrm{~km}$.

Se considerarmos que o consumo médio de combustível do caminhão poliguindaste duplo é de $4 \mathrm{~km} / \mathrm{L}$ e que o preço do litro do diesel custa para a empresa $\mathrm{R} \$ 3,00$ reais, teremos uma economia em combustível aproximada de $\mathrm{R} \$ 189,45 /$ mês.

E uma redução significativa nas emissões de $\mathrm{CO} 2$, cerca de $575 \mathrm{Kg}$ de $\mathrm{CO}_{2}$ seriam deixados de ser descartados no ambiente. Dados calculados pelo site SOS mata Atlântica. (SOS MATA ATLÂNTICA, 2019)

\subsection{REQUISITOS DE PROJETO}

Os principais requisitos do sistema são:

- Funcionar com alimentação elétrica própria além de possuir autonomia de mínima de 15 dias.

- Deve ser uma solução de baixo custo.

- Ser capaz de conectar-se à internet, para envio dos dados coletados a uma taxa de amostragem e de transmissão de uma hora no mínimo.

- Deve suportar temperaturas de até $60 \stackrel{\circ}{\circ}$. Temperatura máxima estimada no interior de um container.

- Deve ser resistente a furtos.

- Distância máxima de 1,35 m a ser medida pelo sensor de nível.

- Deve possuir um servidor web para armazenamento e disponibilização dos dados coletados. 


\section{DESENHO DO SISTEMA DE TELEMETRIA}

O protótipo será composto por dois subsistemas, o subsistema central, que ficará instalado na cede da empresa e tem objetivo de carregar as baterias dos contêineres. E o subsistema móvel que será instalado nos contêineres. Este é responsável pela leitura do nível de cada contêiner e envio das informações para o servidor web, que concentrará todas as informações. Um diagrama em blocos do sistema é exibido na Figura 11.

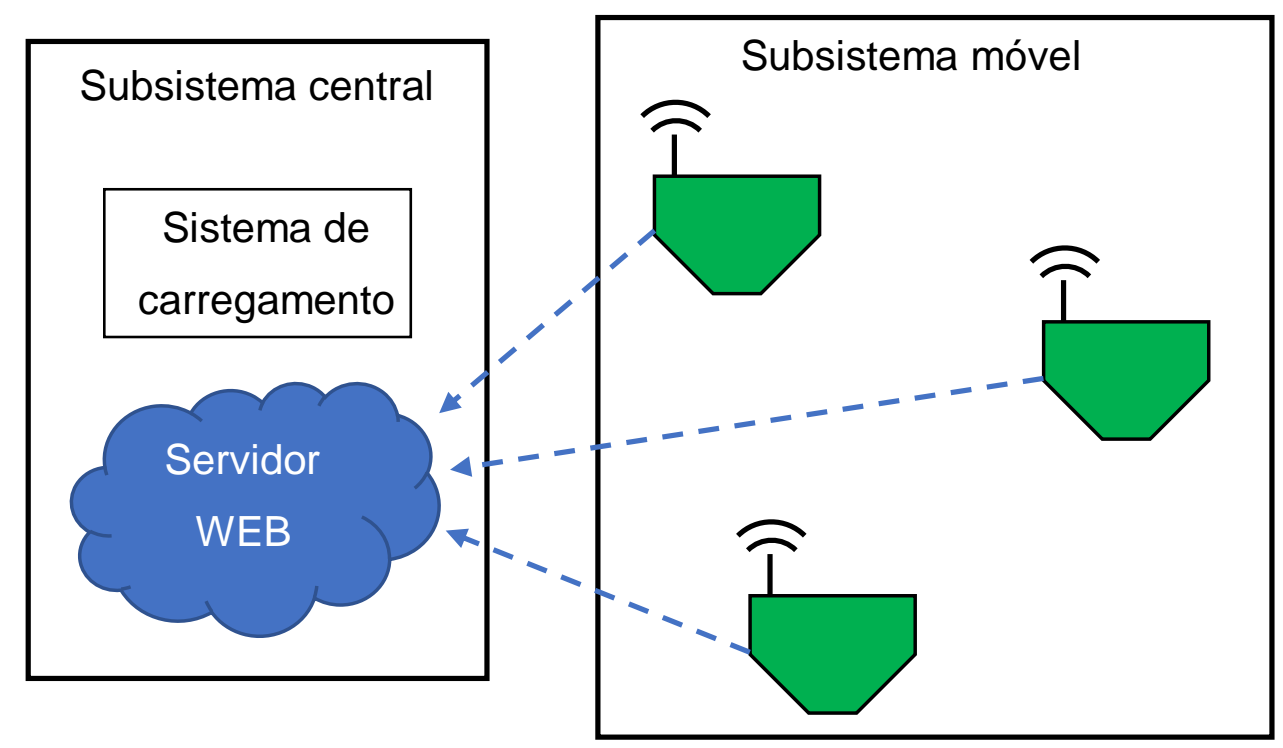

Figura 11. Diagrama esquemático do sistema de telemetria

\subsection{SUBSISTEMA MÓVEL}

O subsistema instalado nos contêineres deve ser capaz de coletar os dados do nível de resíduos no interior do contêiner e envia-los para o servidor web. Os componentes principais deste subsistema são: o microcontrolador Attiny 85, módulo GPRS/GSM SIM800L, uma bateria de lítio de 3,7 V, sensor de distância ultrassônico HC-SR04P, cartão SIM M2M para sistemas de telemetria e outros componentes eletrônicos como capacitores, resistores e diodos que serão citados em seções posteriores.

\subsubsection{MÓDULO GPRS/GSM SIM800L}

O SIM800L é o módulo GPRS/GSM fabricado pela empresa SIMCOM, é um dispositivo que pode ser classificado como quad-band, pois pode operar em quatro bandas de frequência. São elas GSM850MHz, EGSM900MHz, DCS1800MHz e PCS1900MHz. O SIM800L possui um slot para microchip de telefonia celular, dessa 
forma ele pode se conectar à rede de telefônica e enviar mensagens, fazer ligações ou enviar dados via GPRS. Neste projeto o módulo funcionará apenas com o sistema GPRS, com um chip fornecido pela empresa Vodafone. Este chip é específico para sistema de rastreamento e telemetria não permite o envio de SMS ou realização de ligações telefônicas.
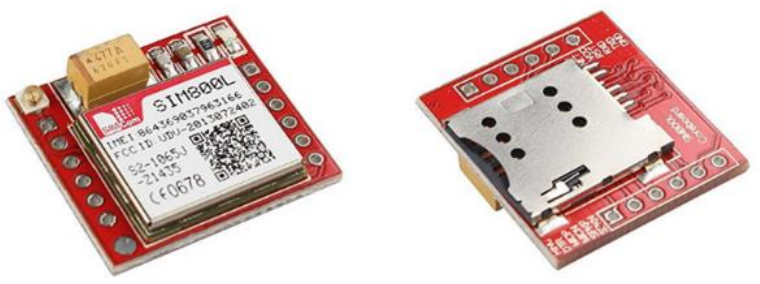

Figura 12. Sim $800 \mathrm{~L}$ da empresa Core Board

Este módulo deve ser alimentado com tensões de 3,4V a 4,4V além de necessitar de no mínimo $2 \mathrm{~A}$ de corrente, pois este é o valor de pico de corrente na transmissão de dados (SIMCOM, 2016). O sistema será projetado para que a tensão da bateria não fique abaixo de $3,4 \mathrm{~V}$.

A comunicação entre o módulo e o microcontrolador é feita via serial, protocolo UART. Por meio de comandos AT é possível registrar o dispositivo na rede de celular, ativar o modo GPRS, se conectar à internet, enviar e receber dados por meio do protocolo de comunicação TCP/IP, além de ativar funções de baixo consumo de corrente entre outros.

Um requisito importante que deve ser analisado para uma boa comunicação entre o microcontrolador e o módulo são os níveis máximos aceitáveis de tensão na porta RX do SIM800L, esta porta não pode receber uma tensão superior a 2,8 V, dessa forma utilizou-se o esquemático da Figura 13, para regular e reduzir a tensão de entrada no pino RX do módulo SIM800L.

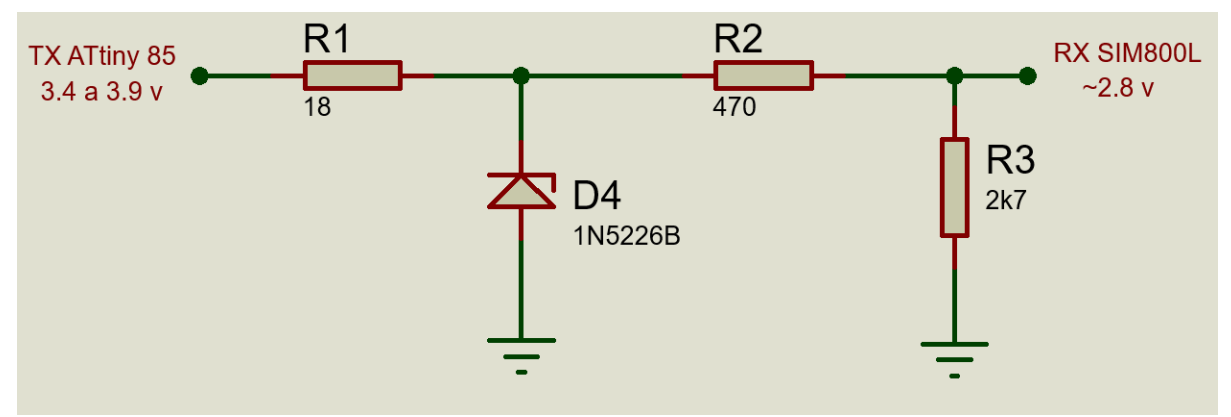

Figura 13. Circuito regulador de tensão 
Para o cálculo de dimensionamento das resistências $R 1$, R2 e R3 foram determinadas as correntes máximas aceitáveis pelo pino de saída digital do microcontrolador e que mantivesse o diodo zener em operação. Para o cálculo foram utilizadas as leis de Kirchhoff, formulas [1], [2] e [3] em duas situações extremas, uma para a tensão máxima fornecida por uma das saídas digitais do Attiny85, 3,9 V, e a outra para a tensão mínima de 3,4 v, pois próximo de 3,3 v o diodo zener deixaria de operar.

$$
I_{R 1}=\frac{V_{T X}-V_{Z}}{R 1}[1] \quad I_{R 2}=\frac{V_{Z}-V_{R X}}{R 2}[2] \quad I_{D 1}=I_{R 1}-I_{R 2}[3]
$$

$I_{R 1}=$ Corrente no resistor 1

$I_{R 1}=$ Corrente no resistor 2

$R 1=$ Resistor 1

$R 2=$ Resistor 2

$V_{T X}=$ Tensão na porta serial TX do Attiny 85

$V_{R X}=$ Tensão na porta serial RX do SIM800L

$V_{Z}=$ Tensão sobre o diodo zenner

$$
\begin{gathered}
V_{T X}=3,4 \\
I_{R 1}=\frac{3,4-3,3}{18}=5,5 \mathrm{~mA} \\
I_{R 2}=\frac{3,3-2,8}{470}=1 \mathrm{~mA} \\
I_{D 1}=5,5-1=4,5 \mathrm{~mA}
\end{gathered}
$$

$$
\begin{gathered}
V_{T X}=3,9 \mathrm{~V} \\
I_{R 1}=\frac{3,9-3,3}{18}=33,3 \mathrm{~mA} \\
I_{D 1}=33,3-1=32,3 \mathrm{~mA}
\end{gathered}
$$

Segundo a fabricante a máxima corrente permitida em uma porta digital do Attiny85 é 40 mA (ATMEL, 2013), visto que o valor de 33,3 mA é inferior ao limite máximo da porta digital este sistema de regulação da tensão na porta serial pode ser utilizado no projeto.

O resistor de $18 \Omega$ limita a corrente que será drenada do ATtiny85 pelo pino TX, quando a bateria está totalmente carregada e o valor de tensão é máximo. Quando a corrente drenada passa pelo zener a tensão aferida nos seus terminais é próxima de 3,3V então os resistores R2 e R3 em forma de divisor de tensão reduzem essa tensão para $2,8 \mathrm{v}$. 


$$
V_{\text {out }}=\frac{R 3}{R 2+R 3} \times V_{\text {in }}
$$

Substituindo os valores de R1 e R2, temos:

$$
V_{\text {out }}=\frac{2700}{470+2700} \times 3,3=2,81 v[5]
$$

As correntes que percorrem R1 e R2 são respectivamente $1,06 \mathrm{~mA}$ e 1,04 fornecendo ao modulo uma corrente de aproximadamente 20uA.

Os resistores de $470 \Omega$ e $2,7 \mathrm{k} \Omega$ foram calculados e utilizados para reduzir a tensão de 3,3 $\mathrm{V}$ para aproximadamente $2,8 \mathrm{~V}$.

Para otimização do consumo de corrente do módulo SIM800L, este deverá ser colocado em modo de "descanso" sempre que não estiver realizando envios de dados. O consumo neste modo é de aproximadamente $1 \mathrm{~mA}$. O comando utilizado para ativação do modo de descanso é o "AT+CSCLK=2" onde o SIM800L reduz seu clock e desliga módulos internos. (SIMCOM, 2016)

Durante o período em que o SIM800L está desativado, o clock é reduzido e reativa a leitura serial periodicamente, se receber alguma informação, o módulo é reativado momentaneamente e aguarda outro comando, que desativa o modo de descanso. Se não receber dados via serial o módulo volta ao modo de baixo consumo automaticamente. Neste projeto para que o módulo desperte são enviados primeiramente o comando "AT" e em seguida o comando de reativação das funções e do clock, "AT+CSCLK=0". (SIMCOM, 2016)

\subsubsection{SENSOR DE NÍVEL}

Para realizar a leitura de nível de resíduos presente dentro do contêiner foi escolhido o sensor de ultrassom HC-SR04P (Figura 14), por ser uma solução de baixo custo e ser compatível aos requisitos do projeto. Este sensor pode ser alimentado com valores de tensão de 3 a $5 \mathrm{~V}$ e possui uma faixa de medição de $2 \mathrm{~cm}$ a $4 \mathrm{~m}$, valor suficiente para medir o nível de resíduos armazenados no interior do contêiner, 1,35 m (Figura 37).
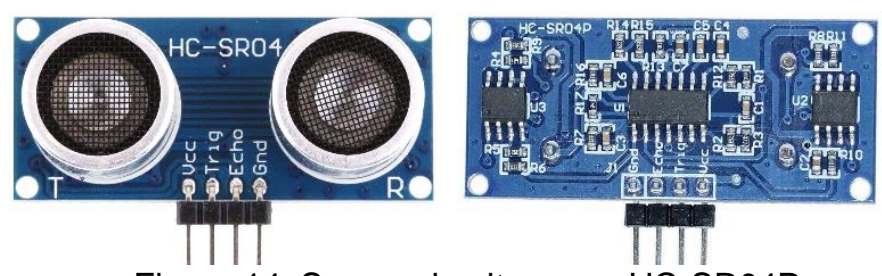

Figura 14. Sensor de ultrassom HC-SR04P 
O HC-SR04P opera recebendo um pulso de 10us proveniente de uma das portas de saída digital do microcontrolador ATtiny 85, o módulo recebe o comando pelo pino TRIGGER, posteriormente envia oito ondas na frequência de $40 \mathrm{kHz}$ e aguarda o retorno do sinal. O pino de saída de sinal do módulo, ECHO, é colocado em nível logico alto no momento que as ondas são enviadas e colocado em nível logico baixo no momento em que o módulo recebe o sinal de retorno.

O Microcontrolador mede o tempo em microssegundos do instante em que a onda foi enviada até que a mesma retorne ao sensor e dessa forma efetua o cálculo da distância percorrida pelas ondas sonoras baseando-se no tempo até o retorno das ondas sonoras. A formula utilizada para o cálculo da distância:

$$
\text { Distancia }[\mathrm{m}]=\frac{\text { tempo em nivel logico alto }[u s] x \text { velocidade do som }(340 \mathrm{~m} / \mathrm{s})}{2}[6]
$$

Fonte: (ELECFREAKS, 2015)

O sensor será alimentado diretamente pelo pino digital número 2 do ATtiny 85 , com objetivo de reduzir o consumo de corrente nos momentos em que o sistema estiver em modo de baixo consumo, pois o consumo de corrente em operação normal do sensor é de $3 \mathrm{~mA}$.

O sensor será posicionado no centro da parte superior interna do contêiner, pelo fato das quatro entradas de resíduos serem posicionadas próximas as extremidades do container (Figura 37). Dessa forma o centro será a última região do container a ser ocupada com resíduos.

Além disso, o sensor de ultrassom escolhido para este projeto não realiza medições em distâncias inferiores a $20 \mathrm{~mm}$ e será fixado à caixa de proteção, que possui altura de $36 \mathrm{~mm}$. Dessa forma o dispositivo possui uma limitação de leitura de $76 \mathrm{~mm}$ na parte superior do container.

\subsubsection{MICROCONTROLADOR}

Para controlar o sistema, enviar comandos AT necessários para o controle de operação do módulo SIM800L e coletar os dados do sensor de ultrassom, foi necessário um microcontrolador capaz de processar todas essas tarefas. O microcontrolador deve possuir pelo menos 5 pinos de entradas e saídas digitais, dois para comunicação serial UART e três para se conectar ao sensor de ultrassom. Também deve ter possibilidade de ser alimentado com tensões de 3,4 a 4,2V. O outro 
critério considerado foi sua disponibilidade no mercado nacional brasileiro, tentando evitar a importação por conta do tempo disponível para a conclusão deste trabalho.

Os seguintes microcontroladores foram analisados, pois são soluções de menor custo e que atendem a especificação básicas de tensão de alimentação e número mínimo de pinos para este projeto. São eles: Atinny85, Atinny13A, PIC12F683 e SC9RS08KA2. Na Tabela 5 são apresentadas as principais características dos microcontroladores analisados:

Tabela 5. Informações relevantes sobre os microcontroladores analisados

\begin{tabular}{|l|c|c|c|c|c|}
\hline Informações relevantes & $\begin{array}{c}\text { ATtiny13 } \\
\text { A }\end{array}$ & Attiny 85 & PIC12F683 & $\begin{array}{c}\text { SC9RS08KA } \\
\mathbf{2}\end{array}$ & $\begin{array}{c}\text { Unidade } \\
\text { s }\end{array}$ \\
\hline Empresa fornecedora & Atmel & Atmel & Microchip & NXP & - \\
\hline Tensão de operação & $1,8-5,5$ & $2,7-5,5$ & $2,0-5,5$ & $1,8-5,5$ & $\mathrm{~V}$ \\
\hline Corrente (operação normal) & 3500 & 3700 & 1000 & 4100 & $\mathrm{uA}$ \\
\hline Corrente (modo econômico) & 4,7 & 4,2 & 2,75 & 1,35 & $\mathrm{uA}$ \\
\hline Frequência de operação & 9,6 & 8 & 8 & 10 & $\mathrm{MHz}$ \\
\hline Instruções por segundo & 8 & 8 & 5 & 5 & $\mathrm{MIPS}^{1}$ \\
\hline Temperatura de operação & $-55 / 125$ & $-55 / 125$ & $-40 / 125$ & $-40 / 85$ & ${ }^{\circ} \mathrm{C}$ \\
\hline Número de pinos & 8 & 8 & 8 & 8 & Pinos \\
\hline Pinos digitais (entrada/saída) & 6 & 6 & 6 & 4 & Pinos \\
\hline Memória Flash & 1 & 8 & 2 & 2 & $\mathrm{~Kb}$ \\
\hline EEPROM & 64 & 512 & 256 & - & Bytes \\
\hline SSRAM & 64 & 512 & 128 & 63 & Bytes \\
\hline Conversor analógico digital & 4 & 4 & 4 & 0 & Unidades \\
\hline
\end{tabular}

${ }^{1}$ Milhões de instruções por segundo.

Fontes: (MICROCHIP, 2019) e (NXP, 2019)

Ao analisar as opções, o microcontrolador da fabricante NXP foi considerado inadequado ao projeto pois não possui a quantidade mínima de 5 entradas ou saídas digitais para o correto funcionamento do projeto. Com relação ao consumo de corrente, aspecto relevante ao projeto visto que o dispositivo será alimentado por uma bateria recarregável e o mesmo deve ficar disponível por 15 dias, o microcontrolador da empresa Microchip se destaca dos demais, por possuir um baixo consumo nos dois modos de operação, normal e em modo económico.

Os dispositivos da fabricante Atmel, possuem características de consumo semelhantes porém o dispositivo ATtiny 85 apresenta um consumo de corrente menor em modo de baixo consumo, modo em que o dispositivo será mais utilizado. Considerando que o sistema estará no modo normal durante 1 minuto a cada 1 hora e o resto do tempo em baixo consumo, vamos considerar apenas este último modo. Dessa forma, o consumo de corrente elétrica em modo de baixo consumo do dispositivo ATtinny85 é 52,7\% superior ao PIC12F683, mas, ambos dois tem valores 
inferiores ao consumo de corrente em baixo consumo do modulo SIM800L, cerca de 1,94 mA (SIMCOM, 2016), tornando pouco relevante a escolha entre os dois dispositivos no quesito corrente de consumo.

A característica determinante na escolha do microcontrolador para este projeto foi o espaço em memória, neste aspecto o dispositivo ATtinny85 se destaca apresentando memória Flash de 8Kb quatro vezes superior ao dispositivo da empresa microchip, além de apresentar uma quantidade maior de instruções por segundo em comparação ao microcontrolador da fabricante Microchip.

Por apresentar baixo consumo, número de portas suficientes e espaço em memória superior aos concorrentes o ATtiny85 foi o microcontrolador escolhido para elaboração deste projeto.

\subsubsection{ATTINY 85}

O microntrolador ATTINY 85, faz parte de um grupo de microcontroladores CMOS de baixa potência de 8-bits, baseado em AVR, um tipo de arquitetura RISC aprimorada. O conjunto de microcontroladores ATtiny foi desenvolvida pela empresa Atmel, porém no ano de 2016 a empresa foi comprada pela Microchip atual responsável pela fabricação e comercialização desses chips. (ATMEL, 2013)

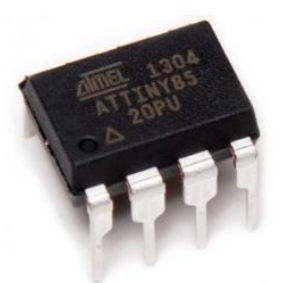

Figura 15. Microcontrolador ATtiny 85

Neste projeto o microcontrolador será implementado em uma arquitetura chamada stand-alone, modelo em que o chip é programado em um gravador ISP e posteriormente é transferido ao seu local de funcionamento permanente no projeto. $O$ Microcontrolador funcionará com clock interno de $8 \mathrm{KHz}$ e será alimentado pela bateria diretamente.

O Attiny 85 é responsável pelo acionamento do sensor de ultrassom bem como o envio de comandos AT para o módulo SIM800L e leitura das respostas provenientes no Módulo de comunicação GPRS. Na Figura 27 é apresentado o esquemático do projeto com todas as ligações físicas que o microcontrolador deve realizar com os demais periféricos. 


\subsubsection{BATERIA}

O sistema deve possuir alimentação própria, pois nos locais de instalação dos contêineres não existe disponibilidade de pontos de energia elétrica. Além disso o sistema deve possuir uma autonomia mínima de 15 dias, maior período de tempo para que um container fique em disposição, informações fornecidas pelo diretor da empresa GreenAmbiental.

Uma característica a ser considerada no cálculo da autonomia do sistema é o fato do descarregamento das baterias não acontecer de forma completa, pois não há no mercado baterias que operam com os valores de tensão exatos de 3,4 a 4,4V. Dessa forma as baterias não trabalharão com sua capacidade máxima, visto a limitação da faixa de tensão deste projeto.

As baterias de Lítio foram escolhidas para implementação neste projeto por apresentarem faixa de tensão aceitável e uma melhor capacidade de corrente em uma célula com menores dimensões. As baterias de Lítio de tensão nominal de 3,7 V apresentam tensão de descarregamento total em 2,75 V. Com uma aproximação linear da faixa de tensão com relação ao tempo de descarregamento de uma bateria de lítio, podemos estimar que neste projeto $55 \%$ da capacidade da bateria será utilizada.

Com relação ao consumo de corrente, o modulo SIM800L, em operação normal, consome 13,42 mA. Porém durante transmissões apresenta picos de até $2 \mathrm{~A}$. Em modo de baixo consumo (Sleep Mode) o modulo consome 1,94 mA (SIMCOM, 2016).

O microcontrolador possui um consumo em operação normal de aproximadamente 3,7 mA, e em modo de baixo consumo a corrente de consumo é de 4,2 uA, considerando o modo de Power Down com o Watchdog timer ativo, necessário para reativação do sistema (ATMEL, 2013). O diodo zener drena uma corrente que varia de $5 \mathrm{~mA}$ a 33,3 $\mathrm{mA}$ a depender da tensão da bateria. Além destes consumos de corrente elétrica deve ser considerado o consumo de $3 \mathrm{~mA}$, referente ao sensor de ultrassom, de forma esporádica, durante o tempo que este fica ligado para realizar o envio e recepção das ondas de ultrasom.

A partir das informações citadas a corrente total drenada da bateria durante a operação normal é de 53,42 mA com picos de $2 \mathrm{~A}$ em pequenos intervalos de tempo. Para o modo de baixo consumo a corrente drenada é de 2,05 mA. 
Para estimar o consumo total do dispositivo, durante uma hora, será considerando que o sistema opere 1 minuto em modo de operação normal e 59 minutos em modo de baixo consumo, este valor do tempo de envio foi obtido experimentalmente em bancada. Dessa forma o sistema terá um consumo de corrente por hora:

Operação normal:

$$
C_{N O R}=\frac{53,42[\mathrm{~mA}] \times 1[\mathrm{~min}]}{60[\mathrm{~min}]}=0,890 \mathrm{mAh}
$$

Operação em baixo consumo:

$$
\begin{gathered}
C_{B C}=\frac{2,05[\mathrm{~mA}] \times 59[\mathrm{~min}]}{60[\mathrm{~min}]}=2,015 \mathrm{mAh} \\
C_{\text {Total }}=C_{N O R}+C_{D E S}=2,905 \mathrm{mAh}
\end{gathered}
$$

$C_{\text {NOR }}=$ Corrente em operação normal

$C_{B C}=$ Corrente em modo de baixo consumo

$C_{\text {Total }}=$ Corrente drenada total durante uma hora

De acordo com os cálculos acima apresentados, será necessária uma bateria com capacidade útil de 1046 mAh para alimentar o sistema durante 15 dias. Dessa forma a bateria escolhida foi uma bateria de íons de lítio recarregável com capacidade de 2200 mAh, e para este projeto serão utilizados 1210 mAh, 55\% da capacidade nominal da bateria. Na Figura 16 uma imagem da bateria selecionada para o dispositivo eletrônico.

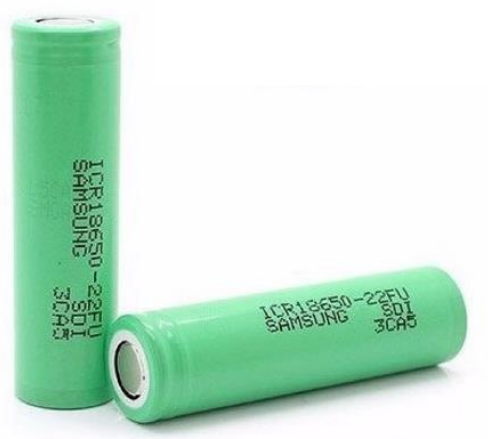

Figura 16. Bateria de lítio, modelo 18650 


\subsubsection{CÓDIGO DE PROGRAMAÇÃO}

O código de programação foi elaborado na plataforma open-source Arduino IDE, em linguagem de programação $C$. $O$ código de programação executa três funções básicas, controladas por uma máquina de estados.

A primeira realiza a leitura do nível, com o acionamento do sensor de ultrassom, envio do pulso trigger, ativação da interrupção por borda de decida e do temporizador para a contagem do tempo. Essa sequência de procedimentos é repetida 20 vezes, com intervalos de um segundo entre cada medição, para que o valor aferido final possua um grau de confiabilidade maior. Após esse processo o software realiza 0 cálculo de distância baseado tempo médio de resposta da onda de ultrassom.

A segunda função é o envio das informações para o servidor web, está tarefa é realizada pelo módulo SIM800L. Na Tabela 6 os comandos necessários para configuração, envio dos dados e desativação do módulo. Cada comando enviado precisa de vários estados da sequência de operação, para enviar, aguardar e analisar a resposta.

Os comandos foram armazenados em memória Flash, na forma de cadeias de texto para reduzir o espaço em memória RAM necessária para o funcionamento do sistema. Uma grande quantidade de tempo e esforço foi dedicado a estudar, testar, validar e otimizar esta função, com base nos manuais da SIM800L e os inúmeros testes que foram necessários.

A terceira função do código é colocar o microcontrolador em modo de baixo consumo. Todo o processo é controlado pelo Watchdog timer, ao ser ativado o modo de baixo consumo o timer aguarda oito segundos e desperta o sistema novamente, incrementando a variável "ciclos" e verificando se a contagem de ciclos atingiu o limite determinado pela variável "tempo_de_envio", se o valor esperado for atingido o microcontrolador desperta e realiza uma nova leitura e envio dos dados para o servidor, se o limite não for atingido o microcontrolador retorna ao modo de baixo consumo por mais um ciclo de desativação, oito segundos. O tempo de amostragem é recebido pelo servidor web a cada envio dos dados, em resposta ao comando "AT+HTTPREAD". 
Tabela 6. Lista de Comandos AT utilizados

\begin{tabular}{|l|l|}
\hline \multicolumn{1}{|c|}{ Comando } & \multicolumn{1}{c|}{ Função } \\
\hline AT & Ativar a comunicação serial \\
\hline AT+CSCLK=0 & Ativar velocidade de clock normal \\
\hline AT+CFUN=1 & Ativar funcionalidades total \\
\hline AT+CBC & Solicita tensão da bateria \\
\hline AT+SAPBR=3,1,"CONTYPE","GPRS" & Configuração HTTP (BEARER) \\
\hline AT+SAPBR=3,1,"APN","simplepm.algar.br" & Configuração HTTP (BEARER) \\
\hline AT+SAPBR=3,1,"USER","algar" & Configuração HTTP (BEARER) \\
\hline AT+SAPBR=3,1,"PWD","algar" & Configuração HTTP (BEARER) \\
\hline AT+SAPBR=1,1 & Configuração HTTP (BEARER) \\
\hline AT+SAPBR=2,1 & Solicita IP \\
\hline AT+HTTPINIT & Início da comunicação HTTP \\
\hline AT+HTTPPARA="CID",1 & Configuração HTTP \\
\hline $\begin{array}{l}\text { AT+HTTPPARA="URL","www.gabtech.xyz/daq.php?d= }= \\
2,4000,33 " ~\end{array}$ & Dados a ser enviados \\
\hline AT+HTTPACTION=0 & Verifica se o envio foi bem sucedido \\
\hline AT+HTTPREAD & Solicita os dados enviados pelo servidor \\
\hline AT+HTTPTERM & Finaliza a comunicação HTTP \\
\hline AT+SAPBR=0,1 & Encerra contexto GPRS \\
\hline AT+CFUN=0 & Ativar funcionalidades mínimas \\
\hline AT+CSCLK=2 & Ativar redução da velocidade do clock \\
\hline
\end{tabular}

A Figura 17 exibe um fluxograma completo com as três funções do código de programação. Na figura podem ser identificados a contagem de erros no envio dos comandos AT, contagem de ciclos para o modo de baixo consumo do microcontrolador e ciclo de vinte medições realizadas pelo sensor de ultrassom. 


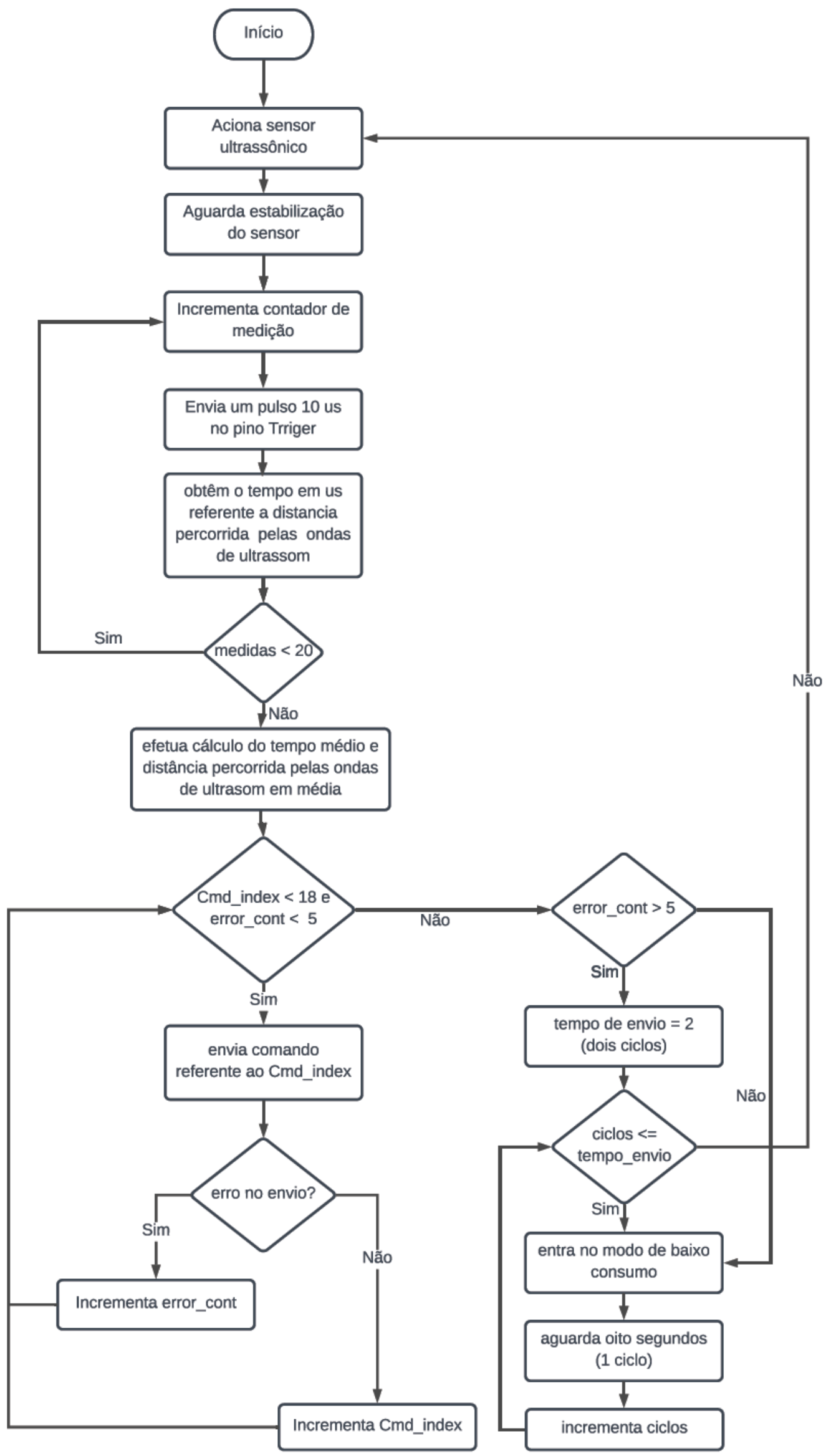

Figura 17. Fluxograma principal do código de programação 


\subsubsection{CAIXA PROTETORA}

O ambiente de instalação do sistema é insalubre, possui resíduos de vidro abrasivos e cortantes que podem danificar os circuitos eletrônicos, além da humidade proveniente dos resíduos líquidos contidos nas embalagens. Por esses motivos optouse pela confecção de uma caixa de proteção (Figura 18), que seja capaz de acomodar todos os dispositivos de forma compacta. As dimensões da caixa de proteção foram dispostas no item 9.3.1.

A caixa será fixada no centro da parte superior do container de resíduos, por meio de quatro parafusos com 3,1 mm de diâmetro por 25,4 mm de comprimento e porcas para o travamento. Todas as dimensões da caixa de proteção podem ser consultadas na sessão de apêndices deste trabalho, item 9.3.

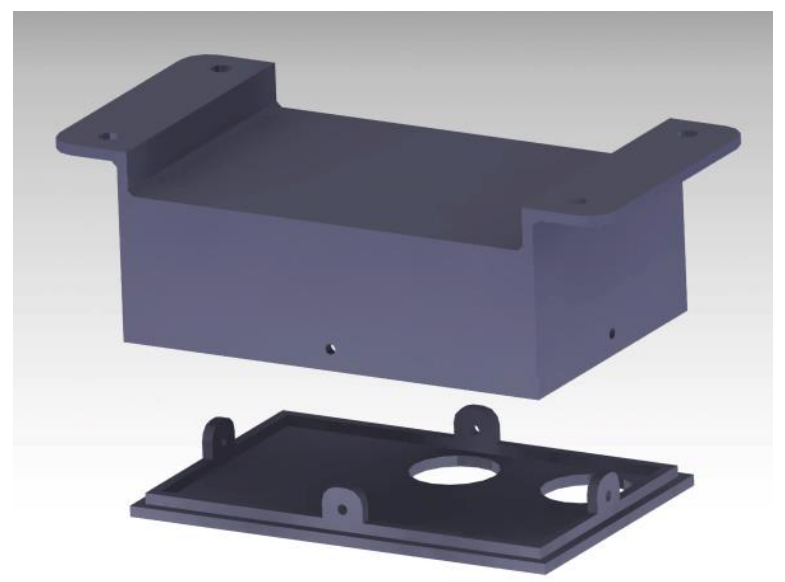

Figura 18. Modelo 3D da caixa de proteção

A seguir, Figura 19, a disposição interna dos componentes na caixa de forma esquemática. O sensor de ultrassom será fixado na tampa da caixa de proteção, voltado para a parte inferior do container. De maneira que seja possível a medição do nível de resíduos no interior do container.

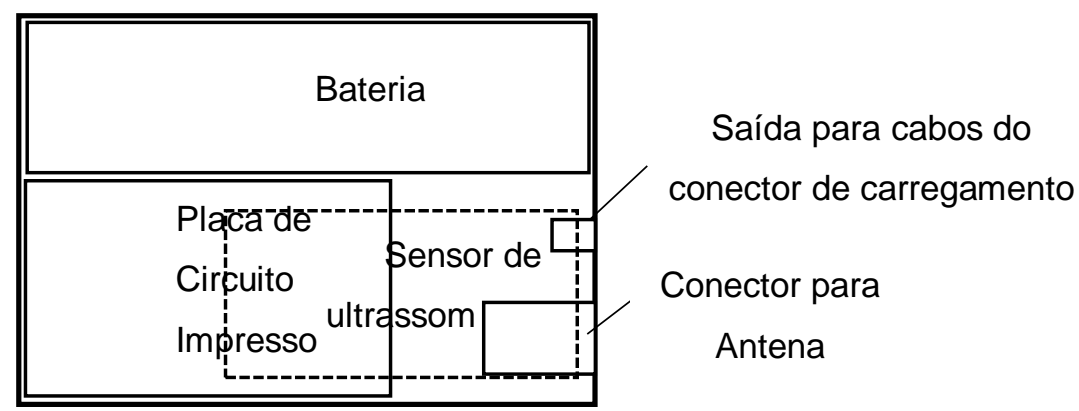

Figura 19. Disposição dos componentes na caixa 


\subsection{SUBSISTEMA CENTRAL}

Este subsistema é composto pelo Servidor WEB e o sistema de carregamento das baterias dos contêineres. O servidor web é responsável pelo armazenamento e apresentação dos dados referentes ao sistema e poderá ser acessado de qualquer dispositivo com acesso à internet dentro ou fora da cede da empresa. Já o dispositivo para carregamento das baterias somente estará disponível na sede da empresa.

Sempre que houver o retorno dos contêineres a sede da empresa o sistema de carregamento será utilizado obrigatoriamente, para possibilitar que as baterias estejam totalmente carregadas antes que os contêineres serem disponibilizados novamente para a coleta.

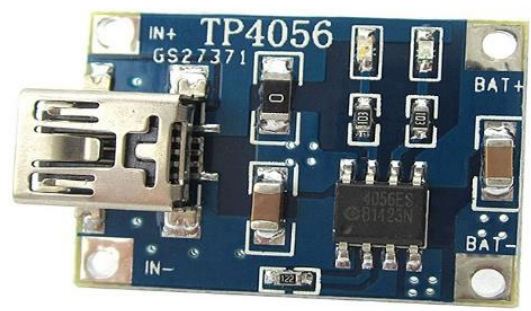

Figura 20. Módulo carregador TP4056 para baterias de lítio de 3,7 V

O sistema de carregamento utiliza o módulo TP4056 (Figura 20), específico para o carregamento de uma célula de lítio com tensão nominal de 3,7 V. A alimentação do módulo carregador é de $5 \mathrm{~V}$ e $1 \mathrm{~A}$ e neste projeto será fornecida por uma fonte para celular ou tablete com conector micro USB, compatível com o conector da placa de carregamento TP4056.

O tempo de carregamento completo para uma bateria de $1000 \mathrm{mAh}$ segundo fabricante é de aproximadamente 1 hora e 48 minutos (Figura 21). Considerando a capacidade nominal da bateria que será utilizada, $2200 \mathrm{mAh}$, proporcionalmente o tempo total de carregamento será de aproximadamente 4 horas. Porém 0 carregamento será realizado de forma parcial, pois neste projeto não serão consideradas tensões inferiores a 3,4 V para alimentação do sistema. O carregamento será realizado de $3,4 \mathrm{~V}$ a $4,2 \mathrm{~V}$, ou seja, cerca de $82,8 \%$ do tempo total de carregamento, cerca de 3 horas e 10 minutos. Em azul na Figura 21 a faixa de trabalho da bateria. 


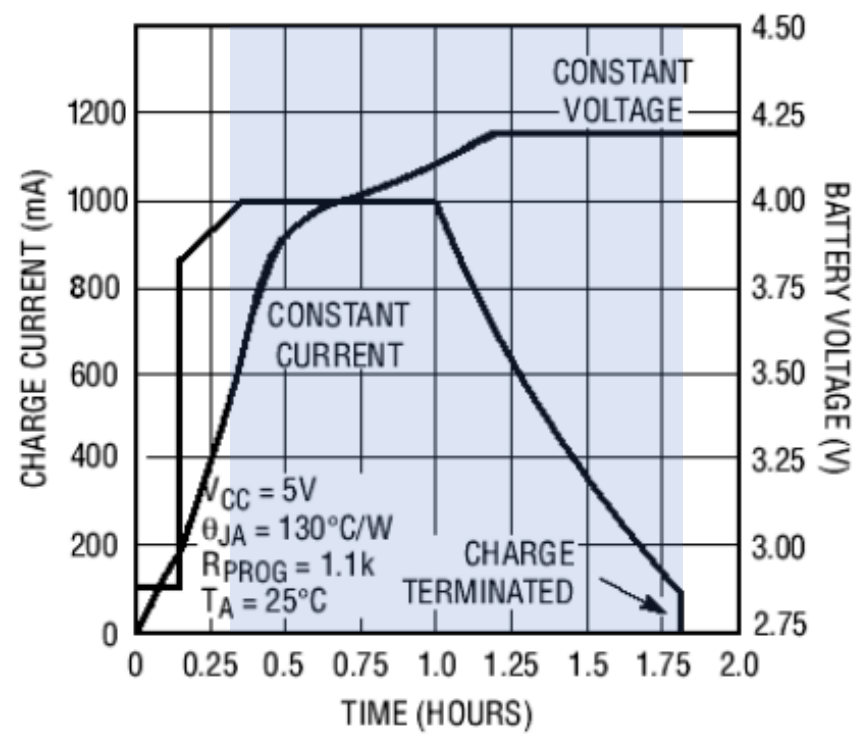

Figura 21. Tensão e corrente durante o carregamento das baterias Fonte: (NANJING , 2018)

Para este projeto serão utilizados dois módulos carregadores, para que seja possível o carregamento das baterias em dois contêineres simultaneamente. Os módulos serão conectados em paralelo em relação a fonte de alimentação como mostra o esquemático abaixo na Figura 22.

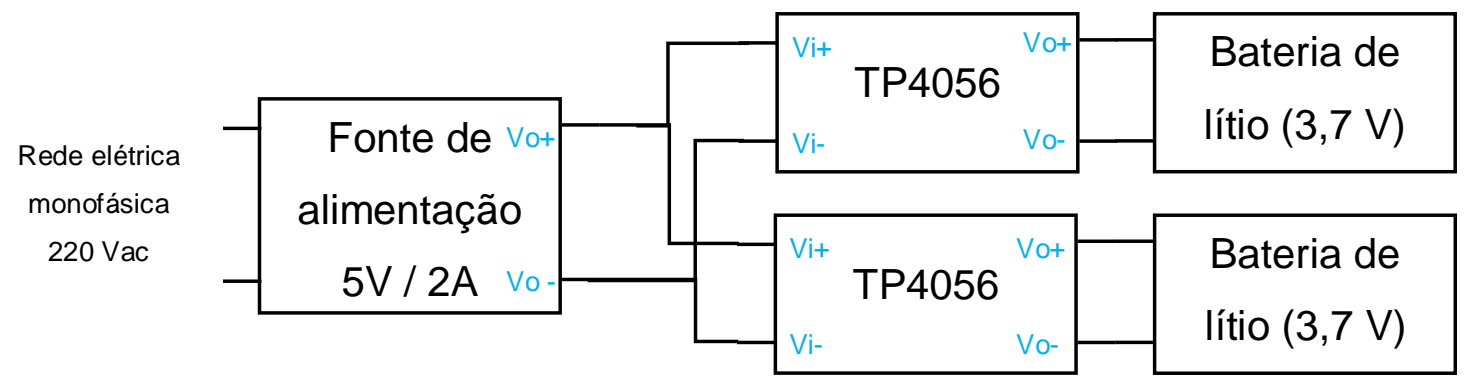

Figura 22. Esquema para carregamento de baterias em dois contêineres.

Elaborado pelo autor

\subsection{PLATAFORMA WEB}

Para que os usuários do sistema tenham acesso as informações dos níveis de resíduos nos contêineres, foi desenvolvida uma página na web. Onde serão registrados os níveis dos contêineres e a evolução histórica do preenchimento de cada container. Dessa forma é possível analisar variáveis importantes para o sistema, como a velocidade em que determinado container fica cheio, períodos sazonais em que o enchimento é mais rápido, identificar locais em que a produção de resíduos é maior, entre outros. 
O sistema web deve aguardar o primeiro alerta de container cheio, a partir desta informação o sistema analisará qual outro container deve ser coletado de maneira que exista uma otimização na eficiência de coleta, da mesma forma como foi elaborado os códigos em linguagem $C$ de simulação da forma otimizada, no item 4.3. O software compara as possíveis rotas de retorno e considera o nível de cada container, então determina qual segundo container deve ser coletado.

Outra alerta importante que deve conter no sistema é a respeito do nível baixo de bateria, valor de tensão inferior a 3,4 V, tensão mínima limite para que aconteça o envio dos dados para o servidor o WEB via GPRS.

\subsection{ESTIMATIVA DE CUSTOS}

Como os resíduos de embalagens de vidro possuem uma margem pequena de lucro, optou-se por buscar no mercado produtos com menor custo que atendessem as especificações do projeto. Nas Tabela 7 e Tabela 8 foram dispostos os custos individuais dos componentes do projeto. A Tabela 7 refere-se aos componentes do sistema instalado nos contêineres, já na Tabela 8 os componentes referentes ao subsistema central.

Tabela 7.Custos componentes do subsistema remoto

\begin{tabular}{|c|c|c|c|c|c|c|}
\hline \multicolumn{7}{|c|}{ Lista de componentes necessários para cada contêiner } \\
\hline \multirow[t]{2}{*}{ Descrição } & \multirow{2}{*}{$\frac{\text { Quant. }}{1}$} & Preço & \multicolumn{2}{|c|}{ Frete } & \multicolumn{2}{|c|}{ Custo } \\
\hline & & $\mathrm{R} \$ 12,60$ & $\mathrm{R} \$$ & 20,00 & $\mathrm{R} \$$ & 32,60 \\
\hline Diodo 1n4728 & 1 & $\mathrm{R} \$ \quad 0,50$ & $\mathrm{R} \$$ & - & $\mathrm{R} \$$ & 0,50 \\
\hline Resistor $(15,1 \mathrm{k}$ e $5 \mathrm{k} 6)$ & 3 & 0,20 & $\mathrm{RS}$ & - & $\mathrm{RS}$ & 0,60 \\
\hline Capacitor eletrolítico 100uF & 1 & 0,50 & $\mathrm{R} \$$ & - & $\mathrm{R} \$$ & 0,50 \\
\hline Componentes eletrônicos adicionais & 1 & 5,00 & $\mathrm{R} \$$ & - & $\mathrm{R} \$$ & 5,00 \\
\hline Conector J4 fêmea & 1 & 2,00 & $\mathrm{RS}$ & - & $\mathrm{RS}$ & 2,00 \\
\hline Sensor de ultrassom (hc-sr04p) & 1 & $\mathrm{R} \$ \quad 13,50$ & $\mathrm{RS}$ & 25,00 & $\mathrm{RS}$ & 38,50 \\
\hline Bateria $18650(3,7 \mathrm{v})$ & 1 & $\mathrm{R} \$ 10,00$ & $\mathrm{R} \$$ & 20,00 & $\mathrm{RS}$ & 30,00 \\
\hline Suporte Bateria & 1 & $\mathrm{R} \$ \quad 2,90$ & $\mathrm{RS}$ & - & $\mathrm{RS}$ & 2,90 \\
\hline Módulo SIM 800 L & 1 & $\mathrm{R} \$ 32,00$ & $\mathrm{R} \$$ & 21,00 & $\mathrm{R} \$$ & 53,00 \\
\hline Antena GPRS/GSM & 1 & $\mathrm{R} \$ 35,00$ & $\mathrm{R} \$$ & 21,00 & $\mathrm{R} \$$ & 56,00 \\
\hline Fabricação PCB & 1 & $\mathrm{R} \$ \quad 10,00$ & $\mathrm{R} \$$ & - & $\mathrm{RS}$ & 10,00 \\
\hline Caixa para proteção do circuito & 1 & $\mathrm{R} \$ 30,00$ & $\mathrm{R} \$$ & - & $\mathrm{R} \$$ & 30,00 \\
\hline Chip SIM CARD & 1 & $\mathrm{R} \$ \quad 7,00$ & $\mathrm{RS}$ & 9,00 & $\mathrm{RS}$ & 16,00 \\
\hline & & & Cus & o total & $\mathrm{R} \$$ & 77,60 \\
\hline
\end{tabular}


Tabela 8.Custo total dos componentes do subsistema central

\begin{tabular}{|c|c|c|c|c|c|c|}
\hline \multicolumn{7}{|c|}{ Lista de componentes para o Subsistema central } \\
\hline Descrição & Quant. & & Preço & Frete & \multicolumn{2}{|c|}{ Custo } \\
\hline Fonte 5V 2A & 1 & $\mathrm{R} \$$ & 25,00 & $\mathrm{R} \$$ & $\mathrm{R} \$$ & 25,00 \\
\hline Módulo Carregador de bateria & 2 & $\mathrm{R} \$$ & 3,50 & $\mathrm{R} \$$ & $\mathrm{R} \$$ & 7,00 \\
\hline Conector P4 macho & 2 & $\mathrm{R} \$$ & 0,66 & $\mathrm{R} \$$ & $\mathrm{R} \$$ & 1,32 \\
\hline & & & & Custo Total & $\mathrm{R} \$$ & 33,32 \\
\hline
\end{tabular}

Os componentes que possuem valor do frete nulo, foram encontrados a venda no Distrito Federal cotados nas empresas HUinfinito e TDtec.

O valor total para implementação do sistema é composto por $R \$ 33,32$ referente aos componentes do subsistema central, mais quatro vezes o valor dos componentes do subsistema remoto, $R \$ 1112,00$. O custo total inicial para implementação do sistema em quatro contêineres é de $R \$ 1145,32$.

Pelo fato do sistema operar por meio de serviço de telefonia móvel, um gasto mensal deve ser adicionado aos custos totais. $O$ valor deste serviço varia a depender da empresa fornecedora, o chip utilizado no protótipo, da empresa Vodafone custa mensalmente $\mathrm{R} \$ 9,00$ com uso de dados ilimitado, mas considerando uma compra de um número maior de unidades pode ser obtido um preço menor.

Além dos custos apresentados, referentes ao sistema eletrônico, temos que acrescentar o custo da hospedagem do site web (hosting) de $R \$ 10$ por mês e do domínio web de $\mathrm{R} \$ 37$ por ano. 


\section{FABRICAÇÃO E VALIDAÇÃO DO PROTOTIPO}

\subsection{SIMULAÇÃO DO CIRCUITO ELETRÔNICO}

O sistema eletrônico foi simulado no software Proteus versão 8.0, da empresa Labcenter Electronics (LABCENTER ELECTRONICS, 2019). Este software permite a simulação de circuitos que contenham microcontroladores, com a inclusão do código de programação durante a simulação. A simulação neste software incluiu a coleta de dados de distância por meio do sensor de ultrassom, envio de comandos AT para o módulo SIM800L e o modo de baixo consumo do microcontrolador Attiny 85 .

O elemento virtual SIM 800 L não está disponível na biblioteca do software, dessa forma para a simulação foi utilizado um terminal serial que realiza a mesma função (Figura 23). O terminal serial exibe na tela os comandos recebidos via comunicação serial por meio da porta $\mathrm{RX}$ e possibilita inserir comandos de resposta que são enviados por meio da porta TX.

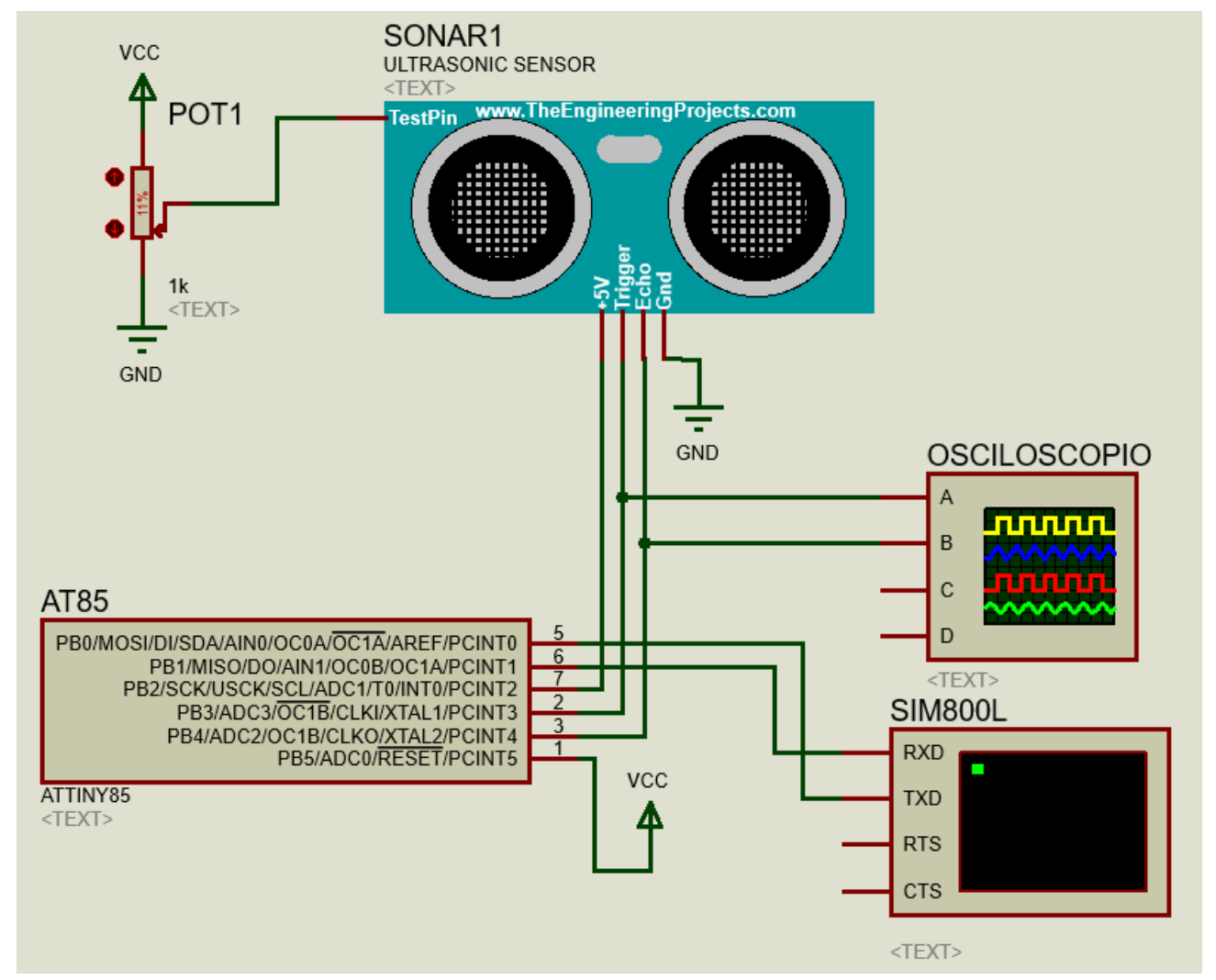

Figura 23. Simulação no software Proteus

O sensor de ultrassom utilizado na simulação é um elemento virtual elaborado pelo Syed Zain Nasir, fundador do site "the engineering projects" (NAZIR, 2015). Este elemento permite simular o tempo de retorno das ondas sonoras por meio da aplicação de uma tensão no pino "TestPin", na simulação fornecida por um 
potenciômetro. A distância virtual dos objetos a frente do sensor de ultrassom é varia proporcionalmente a tensão aplicada no pino de teste.

Além dos elementos citados, um osciloscópio foi utilizado para identificação dos pulsos nos pinos TRIGGER e ECHO do sensor de ultrassom. Na Figura 24 o gráfico gerado pelo osciloscópio em uma das medições realizadas nos testes. A linha azul representa o sinal enviado ao pino TRRIGER e a linha de cor laranja representa o sinal de resposta gerado pelo sensor de ultrassom.

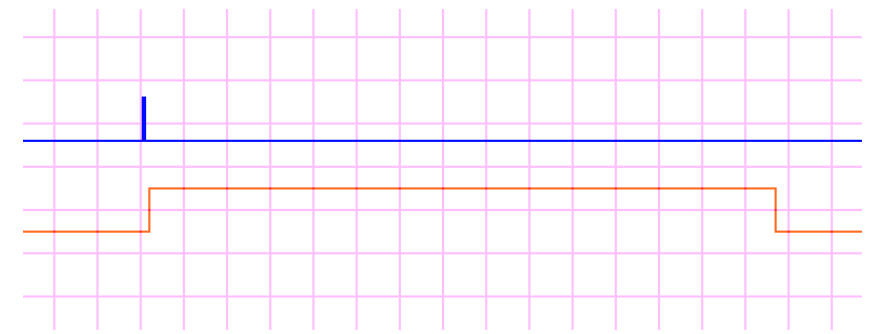

Figura 24.Gráfico gerado pelo osciloscópio nas simulações.

Na Figura 25 as informações sobre a simulação completa, dados como o tempo em milissegundos em que o pino ECHO permanece em nível lógico alto, a distância correspondente ao tempo medido, e os envios de comandos AT e as respostas a cada comando e o início do modo de baixo consumo tanto do SIM800L como do Attiny 85, Após a resposta "OK" do último comando "AT+CSCLK=2".

No exemplo da Figura 25 após cinco minutos o sistema é reativado e repete todo o processo de leitura e envio de informações para o servidor. O tempo entre os envios é configurado pelo servidor web em resposta ao comando "AT+HTTPREAD", no exemplo foi 0005. 


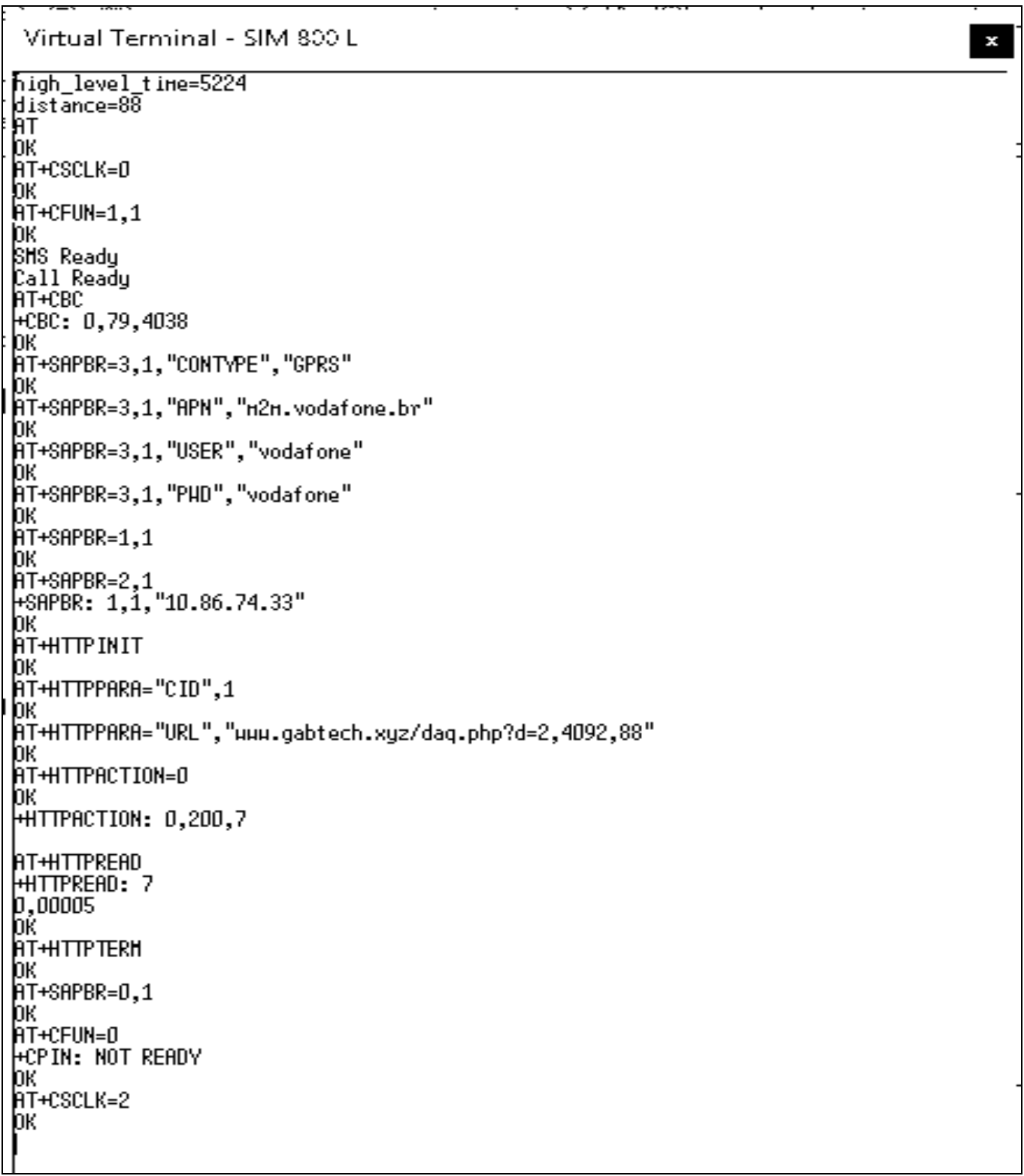

Figura 25. Resultado da simulação em Software

Foram simuladas situações de erros nas respostas, caso algum dos comandos enviados pelo attiny85 ao SIM800L não fosse corretamente interpretado, o comando seria reenviado até cinco vezes, se o erro persistir o sistema entra em modo de baixo consumo por 16 segundos e reinicia o processo de leitura e envio dos comandos AT. Na Figura 26 um exemplo em que os três primeiros comandos foram respondidos com sucesso e o quarto comando não retornou a resposta esperada. 


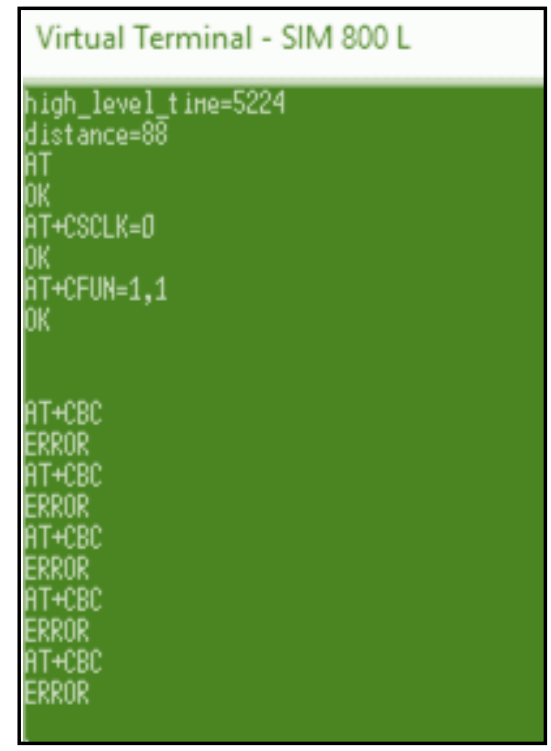

Figura 26. Possíveis respostas do módulo SIM800L

\subsection{DESENHO E FABRICAÇÃO DO PROTOTIPO}

A placa de circuito impresso foi desenvolvida no software Proteus, o mesmo software utilizado para as simulações. Porém para desenvolvimento da $\mathrm{PCl}$ o sensor de ultrassom e o módulo SIM800L foram substituídos no esquemático por conectores, de acordo com a necessidade de cada componente (Figura 27).

Um conector DC POWER JACK foi escolhido para conectar o carregador instalado na central de armazenamento da empresa ao sistema eletrônico instalado no container. Este conector é circular e de fácil utilização por qualquer colaborador da empresa.

Durante o tempo que o sistema estiver no pátio da empresa, em carregamento, não há necessidade de leitura do nível de resíduos no seu interior. Por esse motivo optou-se por utilizar um plugue DC Jack fêmea de três terminais, dos quais um deles funciona como um interruptor, no instante em que o conector DC JACK macho estiver conectado à fêmea o ramo positivo do circuito eletrônico é desconectado da bateria, por outro lado no momento em que o conector macho é desconectado o sistema é reconectado a bateria.

Para reduzir as quedas de tensão na bateria durante o envio de dados pelo modulo SIM800L, momentos em que a corrente atinge picos de $2 \mathrm{~A}$, foi adicionado um capacitor de $100 \mu \mathrm{F}$ entre os terminais da bateria para estabilizar a tensão de alimentação do sistema. 


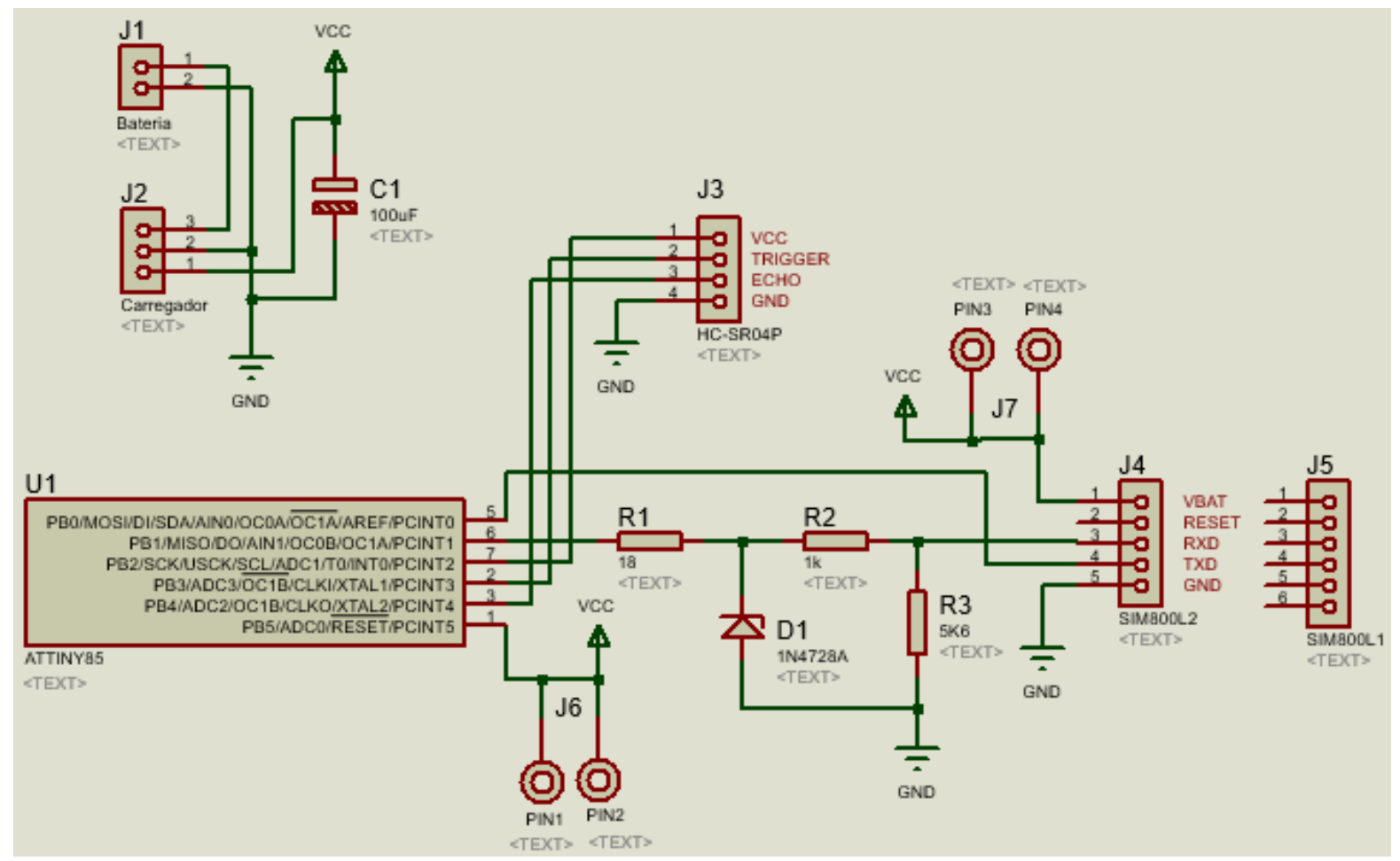

Figura 27. Esquemático para elaboração da PCB

Com objetivo de reduzir o tamanho da placa de circuito impresso de uma camada, foram adicionadas duas conexões na face superior da PCI, J6 e J7 (Figura 28).

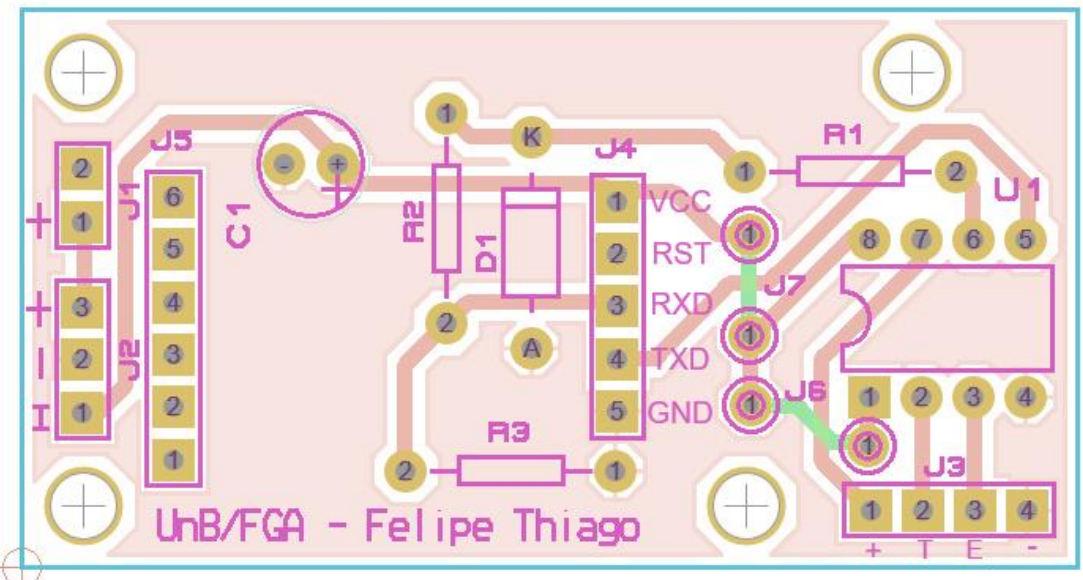

Figura 28. Projeto placa de circuito impresso

A placa de circuito impresso foi confeccionada pelo modo de transferência térmica, no qual as trilhas da Placa são impressas em uma impressora laser em papel tipo couché, ao aquecer a superfície do papel e pressioná-lo contra uma placa de fenolite revestida de cobre, é possível realizar a transferência da imagem impressa no papel couché para a placa de fenolite. Após a transferência a placa é colocada em 
contato com percloreto de ferro, para que o cobre exposto reaja quimicamente e se desprenda da placa, permanecendo apenas as trilhas de cobre cobertas pela tinta transferida para placa.

A placa de circuito impresso possui dimensões de $27 \times 51 \mathrm{~mm}$ e será fixada a caixa de proteção por quatro parafusos de $3 \mathrm{~mm}$ de diâmetro por $5 \mathrm{~mm}$ de comprimento. A seguir na Figura 29 a placa de circuito impresso concluída.
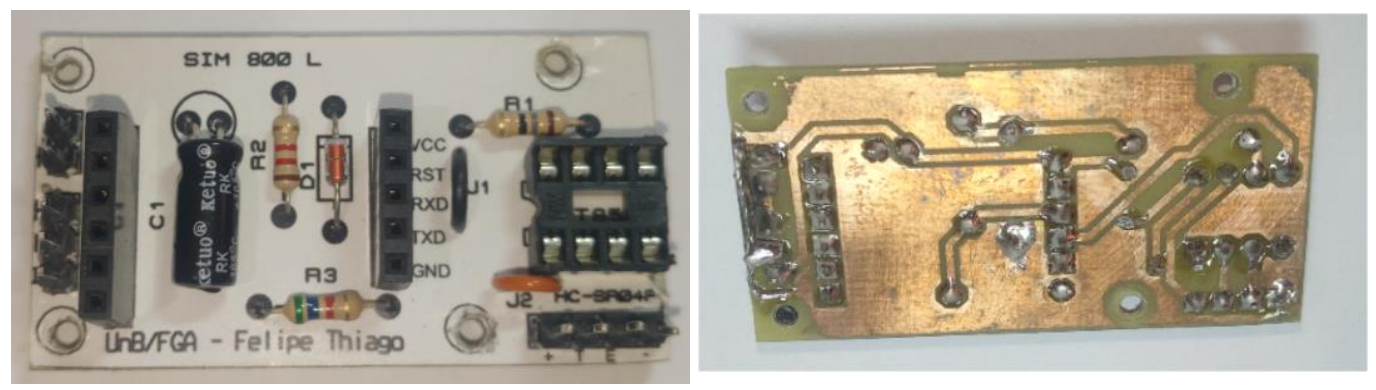

Figura 29. Placa de circuito impresso

A caixa de proteção foi impressa em material polimérico, do tipo ABS em uma impressora 3D, fornecida pelo professor Rhander Viera da Universidade de Brasília Campus Faculdade do Gama Na Figura 30 o sistema com todos os elementos conectados dentro da caixa de proteção

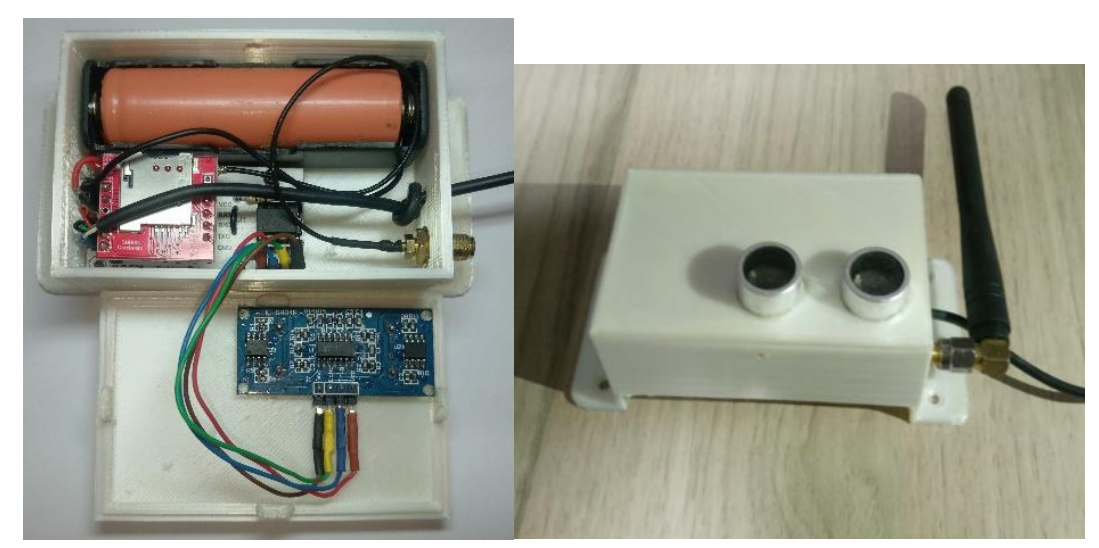

Figura 30. Protótipo finalizado

\subsection{SITE WEB E BASE DE DADOS}

O site web para os testes e validação do sistema foi desenvolvido utilizando a linguagem de programação PHP e a base de dados MySQL. O site foi hospedado nos servidores da empresa Hostinger (HOSTINGER, 2019) no domínio "http://www.gabtech.xyz".

Um conjunto de comandos listados a seguir foram especificados para o envio e consulta e eliminação dos dados de cada contêiner. Esses comandos utilizam 
solicitações GET () sobre o protocolo HTTP (), através do serviço GPRS fornecido pela empresa CastroSat Soluções Tecnológicas. Todos iniciam com o nome do domínio e depois o comando.

Tabela 9. Comandos usados na comunicação com o servidor web.

\begin{tabular}{|c|c|c|}
\hline Função & Comando & Resposta do servidor \\
\hline Listar medições & $\begin{array}{l}\text { test.php?d=<id do } \\
\text { contêiner }>\end{array}$ & $\begin{array}{l}\text { Lista de medições do contêiner <id do } \\
\text { contêiner }> \\
<\text { data e horário >,<nível>,<tensão da } \\
\text { bateria }>\end{array}$ \\
\hline Enviar medição & $\begin{array}{l}\text { daq.php?d=<id do } \\
\text { contêiner }>,<\text { tensão da } \\
\text { bateria }>,<\text { nível }>\end{array}$ & $\begin{array}{l}<\text { código de erro }>,<\text { período de } \\
\text { amostragem em segundos }>\end{array}$ \\
\hline $\begin{array}{l}\text { Eliminar } \\
\text { medições }\end{array}$ & $\begin{array}{l}\text { del.php?d=<id do } \\
\text { contêiner }>\end{array}$ & $\begin{array}{l}\text { As medições do contêiner <id do } \\
\text { contêiner> foram eliminadas }\end{array}$ \\
\hline $\begin{array}{l}\text { Modificar período } \\
\text { de amostragem }\end{array}$ & $\begin{array}{l}\text { def.php?st=<tempo em } \\
\text { minutos }>\end{array}$ & $\begin{array}{l}\text { Tempo de amostragem modificado para } \\
<\text { tempo> minutos }\end{array}$ \\
\hline
\end{tabular}

A seguir a estrutura da base de dados relacional utilizada para armazenar os dados recebidos pelo servidor. Os dados são relacionados em duas tabelas, uma com informações próprias de cada container e a outra com os dados recebidos pelo dispositivo eletrônico.

\begin{tabular}{|c|c|c|c|c|c|c|c|c|c|c|c|c|c|}
\hline \multirow[b]{2}{*}{ \# } & \multicolumn{6}{|c|}{ Estrutura da tabela contêiner } & \multicolumn{7}{|c|}{ Estrutura da tabela medições } \\
\hline & Nome & Tipo & Nulo & Predefinido & Comentários & Extra & $\#$ & Nome & Tipo & Nulo & Predefinido & Comentários & Extra \\
\hline 1 & id $\rho$ & int(11) & Não & None & & AUTO_INCREMENT. & 1 & id 2 & int(11) & Não & None & & AUTO_INCREMENT \\
\hline 2 & name & text & Não & None & & & 2 & container & int(11) & Não & None & & \\
\hline 3 & latitude & float & Não & None & & & 3 & date & datetime & Não & None & & \\
\hline 4 & longitude $f$ & float & Não & None & & & 4 & nivel & float & Não & None & & \\
\hline 5 & filled_time it & int(11) & Não & None & days & & 5 & battery & float & Não & None & & \\
\hline 6 & capacity in & int(11) & Não & None & $\mathrm{Kg}$ & & & & & & & & \\
\hline 7 & active & tinyint(1) & Não & None & If true the conte & & & & & & & & \\
\hline
\end{tabular}

Figura 31. Base de dados relacional

Por enquanto não foram utilizadas camadas de proteção ou autenticação na comunicação por ser um protótipo sem utilização comercial real. Mas, se o sistema fosse implementado de forma comercial seria preciso usar comunicação segura (por exemplo SSL) e autenticação para o aceso ao sistema, além de ferramentas para a optimização dos cursos da coleta e uma interface de usuário que facilite o aceso ao sistema. 


\subsection{TESTES E VALIDAÇÃO DO PROTÓTIPO}

A validação final do dispositivo foi realizada em duas etapas, na primeira o código de programação referente a todas operações do sistema foi gravado no microcontrolador Attiny 85, por meio da placa de desenvolvimento de projetos Arduino UNO, funcionando como um gravador ISP (Figura 32). Na segunda a mesma placa de desenvolvimento Arduino é utilizada para monitorar a comunicação serial entre o Atinny85 e o módulo SIM800L, permitindo supervisionar os comandos AT enviados para o módulo SIM800L e suas respectivas respostas.

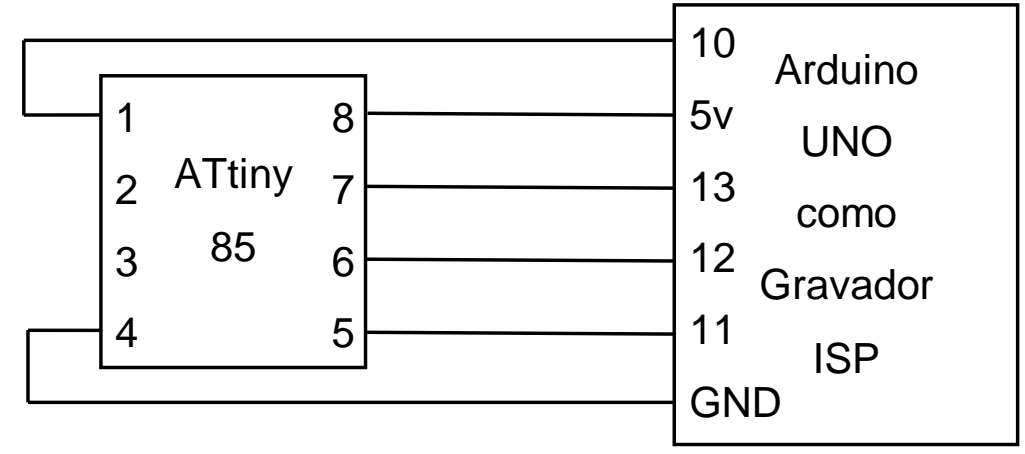

Figura 32. Esquemático para carregar o script no ATtiny 85 Fonte: (WELAUSEN, 2019)

Para que o dispositivo Arduino possa obter os dados da comunicação serial entre o modulo SIM800L e o Attiny85 foi necessário a implementação de um circuito conversor de nível lógico (Figura 33). Este circuito realiza o ajuste entre o nível lógico de 2,8V do módulo SIM800L para os 5V do Arduino UNO.

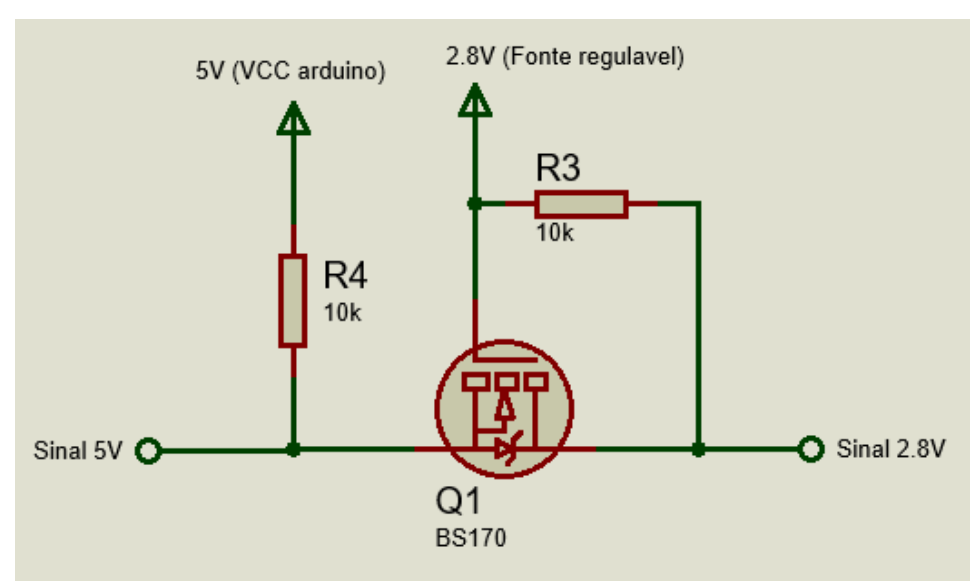

Figura 33. Circuito adaptador de nível lógico

Fonte: (RAPETTI, 2017)

Os testes práticos mostraram algumas diferenças em relação aos testes em software, algumas respostas do modulo SIM800L são enviadas com caracteres adicionais, como caracteres que indicam espaço ou próxima linha. Dessa forma 
ajustes na contagem dos caracteres de leitura realizados nas respostas dos comandos "AT+CBC" e "AT+HTTPREAD" foram necessários.

Na Figura 34 as mensagens obtidas através do monitor serial do compilador IDE Arduino em um teste completo, as mensagens abaixo representam as respostas enviadas pelo SIM800L para o microcontrolador attiny 85.

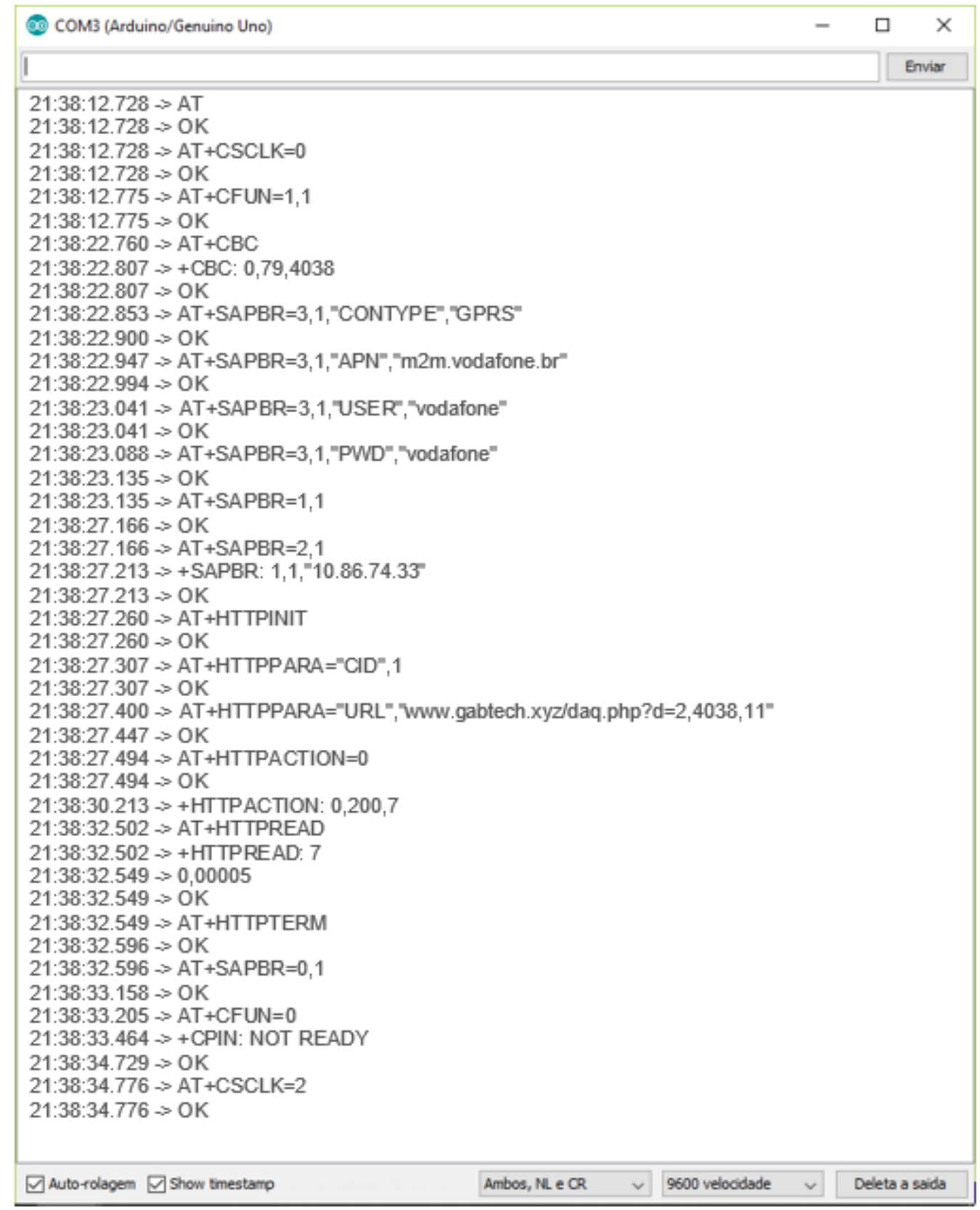

Figura 34. Respostas aos comandos AT enviados ao SIM800L

O envio dos comandos AT apesar dos ajustes foram bem sucedidos, o dispositivo respondeu bem aos comandos realizando o envio dos dados para o servidor. Após esta etapa o monitor serial foi desconectado do projeto, para analisar sua operação 
sem a influência deste elemento. Os envios continuaram a ser realizados e os valores puderam ser consultados no servidor.

Os dados de leitura foram recebidos com sucesso no site web, Figura 35, dispostos em: data, horário, nível da bateria em milivolts e distância aferida em centímetros.

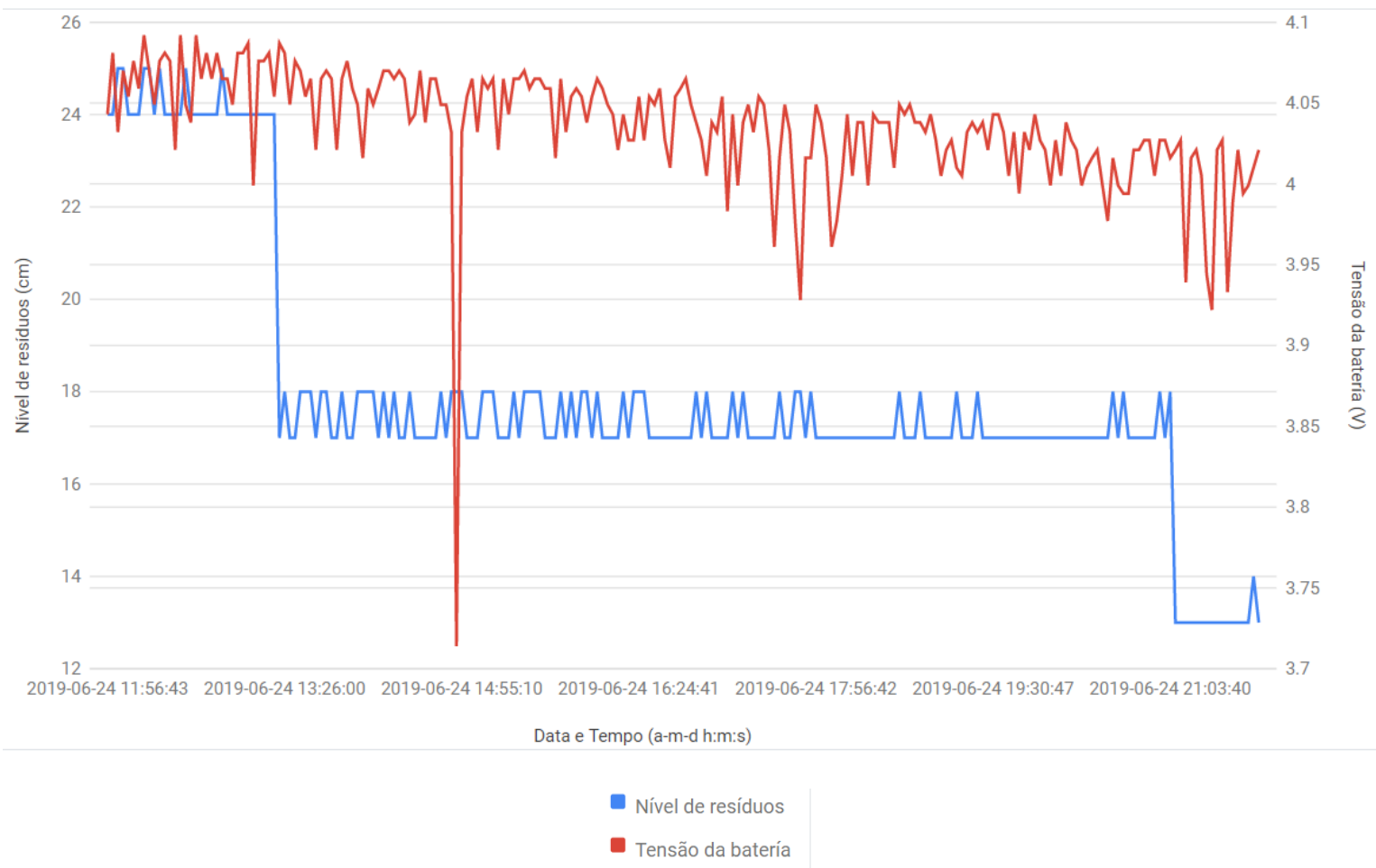

Figura 35. Dados recebidos pelo site web

Com relação ao erro de leitura do dispositivo, é necessário considerar o espaço em memória do microcontrolador, por esse motivo optou-se por reduzir a precisão das leituras realizadas pelo dispositivo. Dessa forma após o microcontrolador realizar o cálculo de distância do sensor até os resíduos, a parte fracionária do resultado é desprezada, para que o valor possa ser armazenado em uma variável do tipo "byte", de 8 bits.

A compensação de distância nos valores medidos foi determinada por um conjunto de 20 medições com o dispositivo distante do obstáculo mais próximo em 65 $\mathrm{cm}$. O valor de compensação determinado foi de $4,8 \mathrm{~cm}$, valor esse que deve ser somado a cada medição, visto que o sensor está fixado na tampa da caixa de proteção e o elemento sensor primário está a $4,8 \mathrm{~cm}$ da parte superior do container, local onde 
o sistema será fixado. Na Tabela 10 é possível verificar como o dispositivo opera e analisar os resultados das medições.

Tabela 10. Teste amostral de medidas

\begin{tabular}{|c|c|c|c|c|c|c|}
\hline $\begin{array}{l}\text { Número } \\
\text { de } \\
\text { medição }\end{array}$ & $\begin{array}{l}\text { Valor } \\
\text { real }\end{array}$ & $\begin{array}{l}\text { Tempo } \\
\text { [us] }\end{array}$ & $\begin{array}{l}\text { Distância } \\
\text { calculada }\end{array}$ & $\begin{array}{c}\text { Distância } \\
\text { considerada }\end{array}$ & $\begin{array}{c}\text { Erro } \\
\text { medição }\end{array}$ & $\begin{array}{c}\text { Erro na } \\
\text { consideração }\end{array}$ \\
\hline 1 & 65 & 3538 & 64,953 & 64 & 0,047 & 1 \\
\hline 2 & 65 & 3540 & 64,982 & 64 & 0,018 & 1 \\
\hline 3 & 65 & 3542 & 65,009 & 65 & $-0,009$ & 0 \\
\hline 4 & 65 & 3532 & 64,842 & 64 & 0,158 & 1 \\
\hline 5 & 65 & 3543 & 65,023 & 65 & $-0,022$ & 0 \\
\hline 6 & 65 & 3541 & 64,989 & 64 & 0,011 & 1 \\
\hline 7 & 65 & 3543 & 65,036 & 65 & $-0,036$ & 0 \\
\hline 8 & 65 & 3541 & 64,995 & 64 & 0,005 & 1 \\
\hline 9 & 65 & 3541 & 65,002 & 65 & $-0,002$ & 0 \\
\hline 10 & 65 & 3541 & 64,990 & 64 & 0,010 & 1 \\
\hline 11 & 65 & 3557 & 65,276 & 65 & $-0,276$ & 0 \\
\hline 12 & 65 & 3545 & 65,063 & 65 & $-0,063$ & 0 \\
\hline 13 & 65 & 3546 & 65,079 & 65 & $-0,079$ & 0 \\
\hline 14 & 65 & 3552 & 65,191 & 65 & $-0,191$ & 0 \\
\hline 15 & 65 & 3554 & 65,218 & 65 & $-0,218$ & 0 \\
\hline 16 & 65 & 3544 & 65,051 & 65 & $-0,051$ & 0 \\
\hline 17 & 65 & 3547 & 65,096 & 65 & $-0,096$ & 0 \\
\hline 18 & 65 & 3554 & 65,220 & 65 & $-0,220$ & 0 \\
\hline 19 & 65 & 3542 & 65,016 & 65 & $-0,016$ & 0 \\
\hline 20 & 65 & 3545 & 65,060 & 65 & $-0,060$ & 0 \\
\hline Média & 65,000 & 3544,380 & 65,054 & 64,700 & 0,079 & 0,300 \\
\hline \multicolumn{5}{|c|}{ Erro absoluto máximo } & 0,276 & 1 \\
\hline \multicolumn{5}{|c|}{ Erro absoluto mínimo } & 0,002 & 0 \\
\hline \multicolumn{5}{|c|}{ Desvio padrão da média dos erros } & 0,085 & 0,470 \\
\hline
\end{tabular}

Para valores no centro da faixa de trabalho o dispositivo apresentou erro de medição médio na variável distância calculada de $0,079 \mathrm{~cm}$, porém este dispositivo arredonda o valor medido desconsiderando a parte fracionária do resultado, dessa forma o erro médio absoluto da variável distância considerada foi de $0,3 \mathrm{~cm}$ em relação ao valor verdadeiro, $65 \mathrm{~cm}$. Como resultado para essa faixa de medição o dispositivo possui um erro máximo de $1 \mathrm{~cm}$.

Um segundo teste foi realizado para identificar as variações nos valores medidos em toda a faixa de trabalho ao qual o dispositivo deve operar, 0 a $135 \mathrm{~cm}$. A Tabela 11 apresenta valores medidos em toda a faixa com alternância de $5 \mathrm{~cm}$ a cada medição. 
Tabela 11. Teste do erro máximo aferido dentro da faixa de trabalho

\begin{tabular}{|c|c|c|c|c|c|c|}
\hline $\begin{array}{l}\text { Número de } \\
\text { medição }\end{array}$ & Valor real & $\begin{array}{c}\text { Tempo } \\
\text { [us] }\end{array}$ & $\begin{array}{l}\text { Distância } \\
\text { calculada }\end{array}$ & $\begin{array}{l}\text { Distância } \\
\text { considerada }\end{array}$ & $\begin{array}{c}\text { Erro } \\
\text { medição }\end{array}$ & $\begin{array}{c}\text { Erro na } \\
\text { consideração }\end{array}$ \\
\hline 1 & 135 & 7532 & 132,849 & 132 & 2,151 & 3 \\
\hline 2 & 130 & 7238 & 127,851 & 127 & 2,149 & 3 \\
\hline 3 & 125 & 6962 & 123,157 & 123 & 1,843 & 2 \\
\hline 4 & 120 & 6650 & 117,848 & 117 & 2,152 & 3 \\
\hline 5 & 115 & 6406 & 113,697 & 113 & 1,303 & 2 \\
\hline 6 & 110 & 6087 & 108,272 & 108 & 1,728 & 2 \\
\hline 7 & 105 & 5795 & 103,315 & 103 & 1,685 & 2 \\
\hline 8 & 100 & 5529 & 98,791 & 98 & 1,209 & 2 \\
\hline 9 & 95 & 5267 & 94,346 & 94 & 0,654 & 1 \\
\hline 10 & 90 & 4958 & 89,083 & 89 & 0,917 & 1 \\
\hline 11 & 85 & 4693 & 84,581 & 84 & 0,419 & 1 \\
\hline 12 & 80 & 4414 & 79,840 & 79 & 0,160 & 1 \\
\hline 13 & 75 & 4116 & 74,767 & 74 & 0,233 & 1 \\
\hline 14 & 70 & 3844 & 70,148 & 70 & $-0,148$ & 0 \\
\hline 15 & 65 & 3547 & 65,099 & 65 & $-0,099$ & 0 \\
\hline 16 & 60 & 3284 & 60,620 & 60 & $-0,619$ & 0 \\
\hline 17 & 55 & 2993 & 55,676 & 55 & $-0,676$ & 0 \\
\hline 18 & 50 & 2707 & 50,819 & 50 & $-0,819$ & 0 \\
\hline 19 & 45 & 2423 & 45,993 & 45 & $-0,993$ & 0 \\
\hline 20 & 40 & 2132 & 41,044 & 41 & $-1,044$ & -1 \\
\hline 21 & 35 & 1832 & 35,951 & 35 & $-0,951$ & 0 \\
\hline 22 & 30 & 1576 & 31,594 & 31 & $-1,594$ & -1 \\
\hline 23 & 25 & 1302 & 26,936 & 26 & $-1,936$ & -1 \\
\hline 24 & 20 & 1016 & 22,070 & 22 & $-2,070$ & -2 \\
\hline 25 & 15 & 733 & 17,263 & 17 & $-2,263$ & -2 \\
\hline 26 & 10 & 423 & 11,986 & 11 & $-1,986$ & -1 \\
\hline 27 & 5 & 0 & 4,800 & 4 & 0,200 & 1 \\
\hline \multicolumn{5}{|c|}{ Erro máximo } & 2,263 & 3 \\
\hline \multicolumn{5}{|c|}{ Erro mínimo } & 0,099 & 0 \\
\hline \multicolumn{5}{|c|}{ Média dos erros } & 0,059 & 0,630 \\
\hline \multicolumn{5}{|c|}{ Desvio padrão da média dos erros } & 1,413 & 1,445 \\
\hline
\end{tabular}

Neste teste o dispositivo apresentou erro máximo de 2,263 cm e um erro na variável distância considerada de $3 \mathrm{~cm}$, aproximadamente 2,22\% em relação a faixa de trabalho total do dispositivo. No Gráfico 1 é possível verificar que medições em valores nos extremos da faixa de trabalho apresentam erros maiores e medidas no centro da faixa de trabalho erros menores. Porém para a forma de trabalho do sistema o erro máximo de $3 \mathrm{~cm}$ é aceitável, pois não causará influência significativa no 
resultado esperado, que a princípio seria indicação aproximada do volume de resíduos no interior dos contêineres.

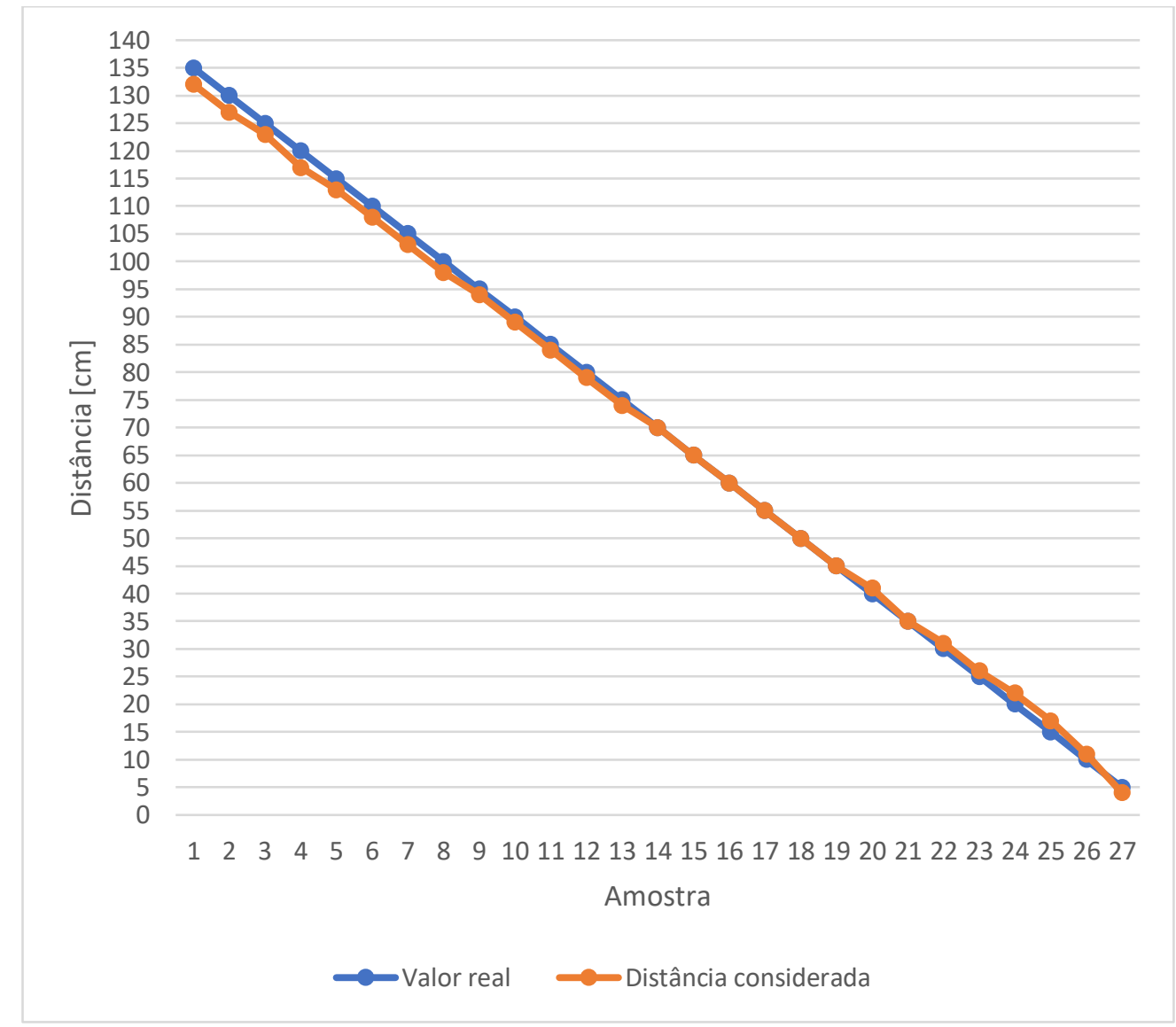

Gráfico 1. Curva de comparação entre o valor real e o valor considerado

A resolução do sistema foi aferida próxima ao meio da faixa de medição, com os valores de $63 \mathrm{~cm}$ à $67 \mathrm{~cm}$, com mudanças de 0,5 cm por medição. Na Tabela 12 os dados obtidos neste teste. O teste mostrou que a resolução do equipamento é de $1 \mathrm{~cm}$, visto que essa é a menor variação de distância que gera uma mudança no resultado final da medição, variável distancia considerada. 
Tabela 12. Teste de da resolução de medição do sistema

\begin{tabular}{|c|c|c|c|c|c|c|c|c|}
\hline $\begin{array}{l}\text { Número } \\
\text { de } \\
\text { medição }\end{array}$ & $\begin{array}{l}\text { Valor } \\
\text { real }\end{array}$ & $\begin{array}{l}\text { Tempo } \\
1 \text { [us] }\end{array}$ & $\begin{array}{l}\text { Tempo } \\
2 \text { [us] }\end{array}$ & $\begin{array}{c}\text { Tempo } \\
\mathbf{3} \text { [us] }\end{array}$ & $\begin{array}{l}\text { Distância } \\
\text { calculada }\end{array}$ & $\begin{array}{c}\text { Distância } \\
\text { considerada }\end{array}$ & $\begin{array}{c}\text { Erro } \\
\text { medição }\end{array}$ & Erro 2* \\
\hline 1 & 63 & 3423 & 3408 & 3416 & 62,863 & 62 & 0,137 & 1 \\
\hline 2 & 63,5 & 3448 & 3438 & 3440 & 63,315 & 63 & 0,185 & 0,5 \\
\hline 3 & 64 & 3477 & 3475 & 3467 & 63,842 & 63 & 0,158 & 1 \\
\hline 4 & 64,5 & 3509 & 3510 & 3510 & 64,465 & 64 & 0,035 & 0,5 \\
\hline 5 & 65 & 3529 & 3532 & 3528 & 64,802 & 64 & 0,198 & 1 \\
\hline 6 & 65,5 & 3559 & 3559 & 3560 & 65,308 & 65 & 0,192 & 0,5 \\
\hline 7 & 66 & 3580 & 3588 & 3589 & 65,755 & 65 & 0,245 & 1 \\
\hline 8 & 66,5 & 3616 & 3609 & 3613 & 66,215 & 66 & 0,285 & 0,5 \\
\hline 9 & 67 & 3640 & 3640 & 3636 & 66,662 & 66 & 0,338 & 1 \\
\hline Média & 65,000 & 3531 & 3529 & 3529 & 64,80 & 64,222 & 0,197 & 0,778 \\
\hline \multicolumn{7}{|c|}{ Erro absoluto máximo } & 0,338 & 1 \\
\hline \multicolumn{7}{|c|}{ Erro absoluto mínimo } & 0,035 & 0,5 \\
\hline \multicolumn{7}{|c|}{ Desvio padrão da média dos erros } & 0,088 & 0,264 \\
\hline
\end{tabular}

${ }^{\star}$ Erro 2 = Erro de arredondamento da variável distancia considerada em relação ao valor verdadeiro

Alguns testes foram executados diretamente nos contêineres para avaliar de que forma o ambiente fechado do container atrapalharia os resultados dos valores medidos pelo sensor de ultrassom. Foram realizados dois testes, com o container vazio e outro com o contêiner cheio, na Figura 36 uma foto do teste realizado no container cheio de resíduos. Os dados apresentaram melhor funcionamento quando as ondas sonoras foram emitidas com intervalo mínimo de tempo de $1 \mathrm{~s}$.

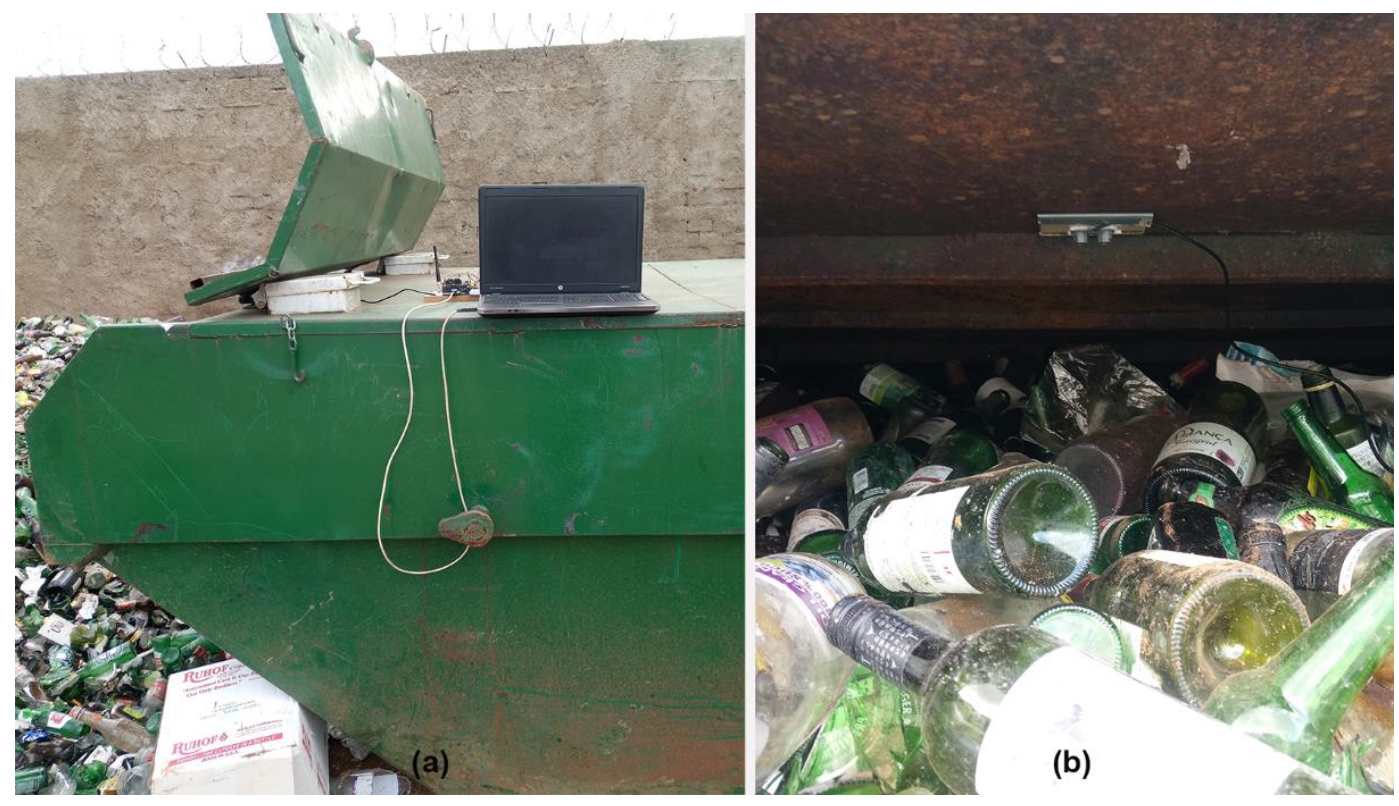

Figura 36. (a) Teste de reflexão das ondas sonoras (b) posicionamento do sensor 
Com relação ao consumo do dispositivo, após a implementação física foram medidas as correntes de consumo dos principais elementos nos dois modos de operação, em operação normal e em modo de baixo consumo, os resultados foram dispostos na Tabela 13.

Tabela 13. Corrente aferidas em laboratório

\begin{tabular}{|l|c|c|}
\cline { 2 - 3 } \multicolumn{1}{c|}{} & \multicolumn{2}{c|}{ Modo de operação } \\
\hline Consumo de corrente & Operação normal & Baixo consumo \\
\hline Attiny 85 & $8,5 \mathrm{~mA}$ & $110 \mathrm{uA}$ \\
\hline HC-SR04P & $3 \mathrm{~mA}$ & 0 \\
\hline SIM 800L & $80 \mathrm{~mA}^{[1]}$ & $1,3 \mathrm{~mA}$ \\
\hline Total & $91,5 \mathrm{~mA}$ & $1,41 \mathrm{~mA}$ \\
\hline
\end{tabular}

[1] Valor médio, durante a transmissão a corrente varia entre $10 \mathrm{~mA}$ e $150 \mathrm{~mA}$, com picos de até $2 \mathrm{~A}$.

Um envio completo e bem sucedido é realizado em cerca de um minuto, o dispositivo passa esse período com consumo de 91,5 mA e passará um intervalo de tempo posterior em modo de baixo consumo, com consumo de 1,41 mA, até que seja realizado um novo envio.

Dessa forma o consumo diário de corrente do dispositivo deve seguir a seguinte formula, que considera a quantidade de envios realizados durante um dia.

$$
C_{\text {dia }}=\frac{N_{\text {envios }} * 91,5+\left(1440-N_{\text {envios }}\right) * 1,41}{60}[\mathrm{mAh}]
$$

De acordo com a empresa Green Ambiental o dispositivo deve ser capaz de ficar 15 dias em campo sem a necessidade de carregar a bateria, ou seja, o consumo máximo durante 15 dias seria de $1210 \mathrm{mAh}$, aproximadamente 80,6 mAh por dia e uma quantidade de envios máximas diárias de aproximadamente 31 envios, seguindo a formula:

$$
N_{\text {envios }}=\frac{60 * C_{\text {dia }}-2030,4}{91,5-1,41}
$$

Dessa forma, o dispositivo atende as especificações com relação a autonomia da bateria, se a quantidade de envios for reduzida o dispositivo pode permanecer em 
operação por mais de 15 dias, esses novos valores podem ser calculados com as formulas (VI) e (VII).

\subsection{CONSIDERAÇÕES FINAIS}

Com base nos testes realizados em bancada, o dispositivo apresentou operação satisfatória, pelo fato de possuir modo de baixo consumo o dispositivo poderá ser utilizado durante 15 dias, sem que se realize o carregamento da bateria.

O projeto foi desenvolvido com elementos de baixo custo, mas que podem ser utilizados de forma definitiva com algumas adaptações, o custo total para instalação do dispositivo eletrônico por container foi de $R \$ 277,60$ com gasto mensal de $R \$ 10,00$ para realizar envios de dados via dados moveis. Uma análise aprofundada dos gastos da empresa seria necessária para estimar com precisão o valor monetário a ser reduzido nos gastos com coleta. Porém com a análise computacional em quatro contêineres foi possível estimar uma redução de $26,6 \%$ na distância percorrida durante a coleta e consequentemente uma redução nos gastos com transporte de resíduos.

O sistema se mostrou eficaz na conexão com a internet, realizando o envio dos dados em diversos locais do Distrito Federal, porém deve possuir antena de no mínimo $3 \mathrm{DBm}$. Sem a antena a conexão com a rede de telefonia celular é instável e certamente atrapalharia o serviço. Outro aspecto relevante é a fixação da antena, esta deve ser fixada na parte externa do container, pois o container metálico atenua consideravelmente o sinal a ser recebido pelo dispositivo.

Com relação a temperatura, todos os componentes do projeto suportam temperaturas de até $85^{\circ} \mathrm{C}$, valor superior ao requisitado, $60^{\circ} \mathrm{C}$. Além caixa de proteção ser fabricada em material plástico para reduzir a condução de calor e possuir um espaço de $8 \mathrm{~mm}$ entre a parte superior do container e a parte superior da caixa de proteção para reduzir a transferência de calor do container para os componentes eletrônico no interior da caixa de proteção.

Para que o dispositivo esteja seguro sua instalação é inteiramente realizada no interior do container, exceto pela antena, que deve estar na parte de fora, de maneira que só poderá ser acessada com o container vazio.

O dispositivo realizou as leituras de nível corretamente, aferidas com régua e trena, respeitando o erro máximo de $1 \mathrm{~cm}$ para valores próximos do centro da faixa e 
$3 \mathrm{~cm}$ para distancias próximas das extremidades da faixa. O dispositivo se mostrou eficaz no consumo de corrente, mesmo não atingindo o seu consumo de corrente mínimo, o consumo de 1,41 mA medido em testes de bancada em modo de baixo consumo permite que o dispositivo possa operar por mais de 15 dias, e com envio de dados a cada hora. 


\section{CONCLUSÕES E RECOMENDAÇÕES}

O projeto físico do dispositivo se mostrou funcional para o que foi proposto, medir o nível de resíduos de embalagens de vidro em contêineres instalados em locais sem a disponibilidades de pontos de energia elétrica localizados no Distrito Federal e realizar o envio dos dados coletados para o servidor WEB.

A cadeia de resíduos de embalagem de vidro passa por dificuldades, visto que o material não possui um valor atraente no mercado de recicláveis, além de ser um material de difícil manipulação, muitas vezes sendo responsável por gerar acidentes em diversos trabalhadores do setor de coleta e manipulação de resíduos. Os responsáveis legais por custear o retorno desse tipo de resíduo para o ciclo produtivo, até o momento não realizaram ações concretas para viabilizar com que os resíduos de embalagens de vidro passem por processo de logística reversa.

O Distrito Federal, representado pelo SLU tomou a atitude menos danosa ao meio ambiente em destinar esses resíduos recicláveis ao aterro sanitário de Brasília, para evitar que se tornem um problema de saúde pública. Este projeto buscou contribuir de forma positiva para o cenário apresentado, reduzindo custos de manipulação para incentivar o aumento da coleta dos resíduos de embalagens de vidro no Distrito federal.

As simulações a respeito da proposta de otimização apresentadas no capítulo 5 mostram uma redução aproximada de $26,6 \%$ dos gastos com transporte primário, porém para validação concreta dos valores apresentados é necessário a aplicação real da solução, pois fatores como a sazonalidade dos dias em uma semana ou dos meses em um ano certamente influencia a quantidade de resíduos depositados nos contêineres e modifica os intervalos das coletas.

Outro fator relevante para uma maior efetividade proposta seria a implementação do sistema em uma quantidade maior de pontos, a medida que se agrega mais pontos ao sistema, as possibilidades de rotas e pontos de coleta possíveis aumentam proporcionalmente de maneira que o sistema terá mais possibilidades de rotas e poderá indicará a melhor opção baseando-se sempre nos níveis dos resíduos de cada contêiner e nas distâncias entre os pontos de interesse.

O sistema foi projetado para uma aplicação especifica, porém com poucas modificações o mesmo desenho pode ser implemento na coleta de outros materiais, ou em empresas que possuam uma forma de trabalho semelhante. É de fácil 
implementação e realocação caso necessário, pois possui alimentação própria e se conecta com a rede de telefonia em qualquer ponto da cidade, apresenta dificuldades de comunicação em zonas com níveis de sinal de telefonia baixo.

Com relação a manutenção do sistema, alguns componentes não estão disponíveis no DF, como por exemplo o microcontrolador Attiny 85 e o sensor de ultrassom HC-SR04P, fato que dificulta a manutenção do equipamento caso haja algum tipo de falha com esses dispositivos, porém os demais elementos do sistema podem ser adquiridos no Distrito federal.

Todos os testes executados, mostraram que o dispositivo é adequado ao proposto e atende as especificações do projeto. Para trabalhos futuros se faz necessária a optimização dos elementos físicos, tornando-os mais robustos fisicamente para suportar todas as adversidades do meio em que serão instalados, com por exemplo proteção a prova d'agua. Além da necessidade de implementar uma comunicação segura entre o dispositivo e o servidor, na internet, para evitar manipulações, roubos e exclusões indevidas dos dados armazenados no site web. Além da inserção de alertas indicativos de contêineres cheios e nível de bateria baixa e indicação das próximas rotas de coleta, diretamente no site, de maneira a facilitar a operação e coleta dos materiais e tornar mais interativo. 


\section{REFERÊNCIAS}

ABIVIDRO. Associação Brasileira das Indústrias de Vidro. Guia reciclagem do vidro: $100 \%$ puro. 100\% reciclável, 2015. Disponivel em: <https://abividro.org.br/2015/07/31/guia-reciclagem-do-vidro-100-puro-100reciclavel/>. Acesso em: 20 jan 2018.

ALAMY. GLASS RECYCLING BOTTLES WASTE BACKGROUND PATTERN, 2013.

Disponivel em: <https://www.alamy.com/glass-recycling-bottles-waste-backgroundpattern-image8914635.html>. Acesso em: 20 Janeiro 2018.

ALVES, J. M. D. C. S. Teleco. Telemedição: As telecomunicações impulsionando a energia, $2017 . \quad$ Disponivel em: <http://www.teleco.com.br/tutoriais/tutorialtelemed/default.asp>. Acesso em: 02 novembro 2018.

ATMEL. Microchip. Atmel 8-bit AVR Microcontroller with 2/4/8K, 2013. Disponivel em: $\quad$ http://ww1.microchip.com/downloads/en/devicedoc/atmel-2586-avr-8-bitmicrocontroller-attiny25-attiny45-attiny85_datasheet.pdf>. Acesso em: 04 Dezembro 2018.

AZEVEDO, V. M. D.; MACIEL, A. M. A.; GAMA, K. S. D. Solução loT de Monitoramento de Poços para Gerenciamento de Recursos Hídricos. Revista de Engenharia e Pesquisa Aplicada, v. 3, n. 3, p. 12, 2019.

BOWERSOX, D. J. In: BOWERSOX, D. J. Logística Empresarial: o processo de integração da cadeia de suprimento. 1ª (2004). ed. São Paulo: ATLAS, 2011. p. 600.

BRASIL. Constituição da República federativa do Brasil, Brasília, DF, 5 out 1988.

BRASIL. Lei ํo 11.445, de 5 de janeiro de 2007. Estabelece diretrizes nacionais para o saneamento básico, Brasília, DF, 05 Jan 2007. 
BRASIL. Lei no 7.404 .445 de 23 de dezembro de 2010. Regulamenta a Lei número 12.305, de 2 de agosto de 2010, Brassília, DF, Dez 2010.

BRASIL. Lei no 5.418, de 24 de novembro de 2014. Dispõe sobre a Política Distrital de Resíduos Sólidos e dá outras providências, Brasília, DF, Nov 2014.

BRASIL. Lei no 5.610 , de 16 de fevereiro de 2016. Dispõe sobre a responsabilidade dos grandes geradores de resíduos sólidos e dá outras providências, Brasília, DF, Fev 2016.

BRASIL. Decreto nำ 9.177, de 23 de outubro de 2017. Regulamenta o art. 33 da Lei no 12.305, de 2 de agosto de 2010, que institui a Política Nacional de Resíduos Sólidos, e complementa os art. 16 e art. 17 do Decreto no 7.404, de 23 de dezembro de 2010 e dá outras providências, Brasília, DF, out 2017.

BRASIL. Diagnóstico do Manejo de Resíduos Sólidos Urbanos - 2017. Sistema Nacional de Informações sobre Saneamento. Brasília, DF, p. 194. 2019.

BRASIL. Sistema Nacional de Informações sobre Saneamento: Diagnóstico do Manejo de Resíduos Sólidos Urbanos - 2017. Ministério das Cidades. Secretaria Nacional de Saneamento Ambiental - SNSA. Brasília, DF, p. 194. 2019.

CALLISTER, W. D.; RETHWISH, D. G. materials science and engineering an instroduction. 8. ed. United States of America: John Wiley \& Sons, Inc., 2009.

CARVALHO, Á. G. D.; LUIS FERNANDO DA COSTA BADINHAN. Eletrônica: Telecomunicações. Coleção Técnica Interativa. Série Eletrônica. ed. São Paulo: Fundação Padre Anchieta, v. 5, 2011.

CATAKI. Cataki. The Recycling Application, 2014. Disponivel em: <https://cataki.org/en/>. Acesso em: 15 dez 2019. 
ELECFREAKS. HC-SR04 HC-SR04 HC-SR04 HC-SR04 User Guide, 2015. Disponivel em: <https://elecfreaks.com/estore/download/EF03085-HCSR04_Ultrasonic_Module_User_Guide.pdf>. Acesso em: 21 dezembro 2018.

GDF. Plano Distrital de Gestão Integrada de Resíduos Sólidos. Governo do Distrito Federal. Distrito Federal, p. 797. 2018.

GIL, A. C. Métodos e técnicas de pesquisa social. 6. ed. São Paulo: Atlas S. A., 2008.

HOSTINGER. Hostinger home, 2019. Disponivel em: <https://www.hostinger.com.br>. Acesso em: 25 Abril 2019.

LABCENTER ELECTRONICS. home, 2019. Disponivel em: <https://www.labcenter.com/>. Acesso em: 28 Mar 2019.

MICROCHIP. 8-bit PIC $\circledast$ and AVR® Microcontrollers, 2019. Disponivel em: <https://www.microchip.com/design-centers/8-bit>. Acesso em: 19 Fev 2019.

MOBILEHELP. MobileHelp Solo, 2018. Disponivel em: $<$ https://www.mobilehelp.com/products/mobilehelp-solo>. Acesso em: 29 outubro 2018.

NANJING. Top Power ASIC Corp. TP4056 1A Standalone Linear Li-lon Battery Charger with Thermal, 2018. Disponivel em: <http://www.haoyuelectronics.com/Attachment/TP4056-modules/TP4056.pdf>. Acesso em: 01 Março 2019.

NAZIR, S. Z. The Engineering Projects. Ultrasonic Sensor Library for Proteus, 2015. Disponivel em: <https://www.theengineeringprojects.com/2015/02/ultrasonicsensor-library-proteus.html>. Acesso em: 01 fevereiro 2019. 
NXP. Arm-Based Processors and MCUs, 2019. Disponivel em: <https://www.nxp.com/products/processors-and-microcontrollers/arm-basedprocessors-and-mcus:ARM-ARCHITECTURE>. Acesso em: 20 Fev 2019.

OTMIS. Otmis - Soluções Jacto para Agricultura de Precisão, 2019. Disponivel em: <https://otmis.com.br/quem-somos>. Acesso em: 17 abr. 2019.

PATRANABIS, D. Telemetry Principles. New Delhi: Tata McGraw-Hill, v. Reimpressão, 1999.

PROTZEK, M. A.; DESCARDECI, J. R. Comunicações por Satélite - Técnicas de Transmissão, Multiplexação e de Acesso. Revista Científica Periódica Telecomunicações, Paraná, v. 4, n. 2, p. 1-17, dez 2001.

RAPETTI, G. Inventable.eu. ADAPTADORES DE NIVEL ENTRE 5V Y 3.3V, 2017. Disponivel em: <https://www.inventable.eu/2017/05/03/adaptadores-nivel-5v-3-3v/>. Acesso em: 18 Março 2019.

RAPPAPORT, T. S. Comunicação sem fio: principios e práticas. 2. ed. São Paulo: Pearson Prentice Hall, 2009.

SIMCOM. SIM800L (MT6261)_Hardware Design_V1.01, 2016. Disponivel em: <https://simcom.ee/documents/SIM800L/SIM800L\%28MT6261\%29_Hardware\%20D esign_V1.01.pdf>. Acesso em: 14 março 2019.

SINIR. Sistema Nacional de Informações sobre a gestão dos Residuos sólidos. Acordo Setorial de Embalagens em Geral, 2018. Disponivel em: <http://www.sinir.gov.br/component/content/article/2-sem-categoria/122-acordosetorial-de-embalagens-em-geral?>. Acesso em: 03 Abril 2018.

SLU. Um ano de operação do Aterro sanitário e tudo pronto para fechar o lixão Relatório de atividades SLU - 2017. Serviço de Limpeza Urbana. Brasília, p. 115. 2017. 
SLU. Serviço de Limpeza Urbana. Coleta seletiva feita por cooperativas tem início em 10 regiões do DF, 2018. Disponivel em: <http://www.slu.df.gov.br/coleta-seletivafeita-por-cooperativas-tem-inicio-em-10-regioes-do-df/>. Acesso em: 03 maio 2018.

SOLUÇÕES INDUSTRIAIS. POLIGUINDASTE BROOKS, 2014. Disponivel em: <https://www.solucoesindustriais.com.br/empresa/transportadores_elevacao_e_mani pulacao_industrial/kabi-industria-e-comercio-s-a/produtos/movimentacao-earmazenagem/poliguindaste-brooks>. Acesso em: 02 março 2018.

SOS MATA ATLÂNTICA. Calcule sua emissão de CO2. Ong SOS Mata Atlântica, 2019. Disponivel em: <https://www.sosma.org.br/projeto/florestas-futuro/comoparticipar/calculadora/>. Acesso em: 09 jul 2019.

STAIR, R. M.; REAYMONDS, G. M. Principios de sistemas de informação. 9. ed. São Paulo: Cengage Learning, 2011.

TECMETRA. Serviços, 2018. Disponivel em: <http://www.tecmetra.com.br/>. Acesso em: 18 Abr 2019.

VARIEMAQ. Locação de caminhão Roll-on, 2017. Disponivel em: <http://www.variemaq.com.br/maquinas-e-equipamentos/locacao-linhapesada/locacao-de-caminhao-rollon-caminhao-roll-on-off/>. Acesso em: 09 Abril 2018.

VERALIA. Reciclagem de vidro, 2010. Disponivel em: $<$ https://br.verallia.com/sustentabilidade/reciclagem-de-vidro>. Acesso em: 09 Abril 2018.

VIDROPORTO. Quem somos, 2019. Disponivel em: <https://www.vidroporto.com.br/>. Acesso em: 16 jan 2019.

WELAUSEN, F. Circuito Maker. ATtinny arcade, 2019. Disponivel em: <https://circuitomaker.com/attiny-arcade/>. Acesso em: 18 Março 2019. 


\section{APÊNDICE}

\subsection{TABELA DE ENTREVISTAS E CONTATOS}

Tabela 14. Tabela de entrevistas e contatos

\begin{tabular}{|c|c|c|c|c|c|}
\hline Data & Função & Empresa & Forma de & & Informação obtida \\
\hline \multirow{4}{*}{ 29/ago } & \multirow{4}{*}{$\begin{array}{l}\text { Supervisor } \\
\text { Técnico }\end{array}$} & \multirow{4}{*}{$\begin{array}{l}\text { Capital recicláveis } \\
\text { (Empresa sucateira) }\end{array}$} & \multirow{4}{*}{$\begin{array}{l}\text { Telefone e e- } \\
\text { mail }\end{array}$} & Tema: & Reciclagem do vidro \\
\hline & & & & $\begin{array}{l}\text { Informações } \\
\text { fornecidas }\end{array}$ & $\begin{array}{c}\text { Não recebem vidro; informou que não é viável a reciclagem de vidro } \\
\text { no DF; o frete sai mais caro que o material }\end{array}$ \\
\hline & & & & Encaminhamentos & $\begin{array}{l}\text { Passou o número do celular do Júnior, dono da empresa casa das } \\
\text { garrafas (61999635151) }\end{array}$ \\
\hline & & & & Dados fornecidos & Nenhum \\
\hline \multirow{4}{*}{$08 /$ set } & \multirow{4}{*}{$\begin{array}{l}\text { Auxiliar de } \\
\text { escritório }\end{array}$} & \multirow{4}{*}{$\begin{array}{l}\text { MAssFIX -mogi das } \\
\text { cruzes - São Paulo }\end{array}$} & \multirow{4}{*}{ Telefone } & Tema: & Reciclagem do vidro \\
\hline & & & & $\begin{array}{l}\text { Informações } \\
\text { fornecidas }\end{array}$ & $\begin{array}{c}\text { Fornecedores: Vidraçarias, montadoras, cooperativas etc; os cacos de } \\
\text { vidro não podem estar misturados com pedras ou pedaços de } \\
\text { porcelana; Material mais limpo tem um valor maior }\end{array}$ \\
\hline & & & & Encaminhamentos & Nenhum \\
\hline & & & & Dados fornecidos & Nenhum \\
\hline \multirow{4}{*}{-} & \multirow{4}{*}{ Diretora } & \multirow{4}{*}{$\begin{array}{l}\text { R3 SANTA MARIA } \\
\text { (Cooperativa) }\end{array}$} & \multirow{4}{*}{ Telefone } & Tema: & Reciclagem do vidro \\
\hline & & & & $\begin{array}{l}\text { Informações } \\
\text { fornecidas }\end{array}$ & $\begin{array}{l}\text { Não reciclam vidro; coletam vidro pela coleta seletiva; o frete sai mais } \\
\text { caro que o material }\end{array}$ \\
\hline & & & & Encaminhamentos & Nildinha está na cooperativa quarta pela manhã \\
\hline & & & & Dados fornecidos & Nenhum \\
\hline
\end{tabular}




\begin{tabular}{|c|c|c|c|c|c|}
\hline \multirow[b]{4}{*}{$18 /$ set } & \multirow[b]{4}{*}{$\begin{array}{l}\text { Responsável } \\
\text { técnica pelos } \\
\text { processos de } \\
\text { beneficiamento }\end{array}$} & \multirow[b]{4}{*}{$\begin{array}{l}\text { MAssFIX -mogi das } \\
\text { cruzes - São paulo } \\
\text { (Beneficiadora) }\end{array}$} & \multirow[b]{4}{*}{ E-mail } & Tema: & Reciclagem do vidro \\
\hline & & & & $\begin{array}{l}\text { Informações } \\
\text { fornecidas }\end{array}$ & $\begin{array}{l}\text { O vidro deve estar livre de contaminantes, tais como: pedra, } \\
\text { porcelana, ferro, metal, cerâmica, concreto, terra e resíduos de } \\
\text { alimentos; a separação feita por cor agrega valor, o vidro incolor é o } \\
\text { que possui maior valor agregado. }\end{array}$ \\
\hline & & & & Encaminhamentos & Nenhum \\
\hline & & & & Dados fornecidos & $\begin{array}{c}\text { Valores que pagam no material: } \\
\text { Vasilhames/Embalagens: Incolor: } \mathrm{R} \$ 200,00 ; \text { Âmbar (Marrom): } \mathrm{R} \$ \\
\text { 160,00; Misto: R\$ 140,00; Espelho: } \mathrm{R} \$ 60,00 ; \text { Laminado/ Parabrisa: } \mathrm{R} \$ \\
\text { 60,00; Caco Incolor e Verde Claro: } \mathrm{R} \$ 190,00 ; \\
\text { Material posto na Massfix - Unid. Mogi das Cruzes. } \\
\text { Vidros Planos: Incolor: R\$ 190,00; Fume e Bronze: } \mathrm{R} \$ 140,00 ; \\
\text { Temperado: } \mathrm{R} \$ 100,00 ; \\
\text { Material posto na Massfix - Unid. Guarulhos. (Valores por cada } \\
\text { tonelada do material) }\end{array}$ \\
\hline \multirow[b]{4}{*}{$14 /$ set } & \multirow{4}{*}{$\begin{array}{c}\text { Auxiliar de } \\
\text { processos }\end{array}$} & \multirow{4}{*}{$\begin{array}{l}\text { Recicle a vida- } \\
\text { Ceilândia-DF } \\
\text { (Cooperativa) }\end{array}$} & \multirow[b]{4}{*}{ Telefone } & Tema: & Processo de coleta e reciclagem dos materiais na cooperativa \\
\hline & & & & $\begin{array}{l}\text { Informações } \\
\text { fornecidas }\end{array}$ & $\begin{array}{l}\text { Recebem vidro pela coleta seletiva; não fazem nenhum tipo de } \\
\text { tratamento com o vidro; acumulam o material e vendem para a } \\
\text { MassFix (lucro de } \mathrm{R} \$ 0,05 / \mathrm{Kg} \text { na última venda). }\end{array}$ \\
\hline & & & & Encaminhamentos & Falar com Francisco SLU (61)32130116 \\
\hline & & & & Dados fornecidos & $\begin{array}{l}\text { Volume de vidro recebido na cooperativa no ano de } 2017 \text { : Janeiro: } \\
1992 \mathrm{~kg} \text {; Fevereiro: } 2066,4 \mathrm{~kg} \text {; Março: } 2433 \mathrm{~kg} \text {; Abril: } 2705 \mathrm{~kg} \text {; Maio: } \\
1913 \mathrm{~kg} \text {; Junho: } 2345 \mathrm{~kg} \text { (Dados obtidos do banco de dados da } \\
\text { cooperativa). Do Banco de dados da associação, receberam } 1119 \mathrm{~kg} \\
\text { no período de } 01 \text { de janeiro a } 30 \text { de junho. }\end{array}$ \\
\hline
\end{tabular}




\begin{tabular}{|c|c|c|c|c|c|}
\hline \multirow{4}{*}{$17 /$ set } & \multirow{4}{*}{$\begin{array}{l}\text { Embaixador do } \\
\text { instituto lixo } \\
\text { zero em Brasília }\end{array}$} & \multirow{4}{*}{-} & \multirow{4}{*}{ Telefone } & Tema: & Instituto lixo zero, reciclagem do vidro \\
\hline & & & & $\begin{array}{l}\text { Informações } \\
\text { fornecidas }\end{array}$ & $\begin{array}{l}\text { Possui um projeto de modelo coleta, que será instalado na vila } \\
\text { planalto (lixo zero); mencionou a existência de uma empresa } \\
\text { recicladora em porto Ferreira, chamada Vidro porto. }\end{array}$ \\
\hline & & & & Encaminhamentos & $\begin{array}{c}\text { Gustavo Bertolino } \\
6133013584 / 6182766736 / \text { Gustavo@7eroimnacto com } \mathrm{rr}\end{array}$ \\
\hline & & & & Dados fornecidos & $\begin{array}{l}\text { Projeto E-cozinha iniciado pelo Paulo melo do restaurante Dona lenha } \\
\text { realiza o envio de embalagens de vidro para reciclagem; }\end{array}$ \\
\hline \multirow{4}{*}{$19 /$ set } & \multirow{4}{*}{ Gerente } & \multirow{4}{*}{ Vidraria Anchieta } & \multirow{4}{*}{ E-mail } & Tema: & Reciclagem do vidro \\
\hline & & & & $\begin{array}{l}\text { Informações } \\
\text { fornecidas }\end{array}$ & Grandes fornecedores de caco no Brasil: Recitotal; Mazzeto; Massfix. \\
\hline & & & & Encaminhamentos & Nenhum \\
\hline & & & & Dados fornecidos & Nenhum \\
\hline \multirow{4}{*}{ 19/set } & \multirow{4}{*}{ Engenheiro } & \multirow{4}{*}{$\begin{array}{l}\text { Vidro porto } \\
\text { (fabrica e } \\
\text { beneficiadora) }\end{array}$} & \multirow{4}{*}{$\begin{array}{l}\text { Telefone e e- } \\
\text { mail }\end{array}$} & Tema: & Reciclagem de vidro e processo de reciclagem \\
\hline & & & & $\begin{array}{l}\text { Informações } \\
\text { fornecidas }\end{array}$ & $\begin{array}{l}\text { Compram cacos de vidro sem beneficiamento, misturados e sujos. } \\
\text { (Eles beneficiam); recebe apenas embalagem de vidro; Se o material } \\
\text { estiver separado por cor, seu valor agregado é maior, O vidro incolor é } \\
\text { o mais valioso; Processo de reciclagem: Eletroímã, sucção de } \\
\text { impurezas leves (canudos, rotulo etc), separação ótica para remoção } \\
\text { das pedras e porcelanas. (Tecnologia estrangeira- empresa PICVISA) }\end{array}$ \\
\hline & & & & Encaminhamentos & Nenhum \\
\hline & & & & Dados fornecidos & $\mathrm{R} \$ 220,00$ a $\mathrm{R} \$ 260,00$ reais/Tonelada \\
\hline \multirow{3}{*}{$19 /$ set } & \multirow{3}{*}{$\begin{array}{l}\text { Auxiliar de } \\
\text { escritório }\end{array}$} & \multirow{3}{*}{$\begin{array}{c}\text { Recitotal } \\
\text { (beneficiadora) }\end{array}$} & \multirow{3}{*}{ E-mail } & Tema: & Reciclagem do vidro \\
\hline & & & & $\begin{array}{l}\text { Informações } \\
\text { fornecidas }\end{array}$ & $\begin{array}{l}\text { Recebem vidro de cooperativas e sucateiros; recebem caco planos de } \\
\text { janela, garrafas e potes; realizam a triagem manual, separando o } \\
\text { material por cor; aceitam apenas sem nenhum tipo de sujeira. }\end{array}$ \\
\hline & & & & Encaminhamentos & Nenhum \\
\hline
\end{tabular}




\begin{tabular}{|c|c|c|c|c|c|}
\hline \multirow{4}{*}{ 07/out } & \multirow{4}{*}{$\begin{array}{l}\text { Paulo melo } \\
\text { filho }\end{array}$} & \multirow{4}{*}{$\begin{array}{l}\text { Restaurante Dona } \\
\text { lenha }\end{array}$} & \multirow{4}{*}{ Telefone } & Tema: & Possível solução para a reciclagem do vidro no distrito federal \\
\hline & & & & $\begin{array}{l}\text { Informações } \\
\text { fornecidas }\end{array}$ & $\begin{array}{c}\text { Total de lixo produzido pelo restaurante } 10 \% \text { é vidro (estudo de caso); } \\
\text { para fabricar novas garrafas a porto Ferreira utiliza } 30 \% \text { de caco(já } \\
\text { beneficiado) e } 70 \% \text { da matéria prima básica, que são os minérios; a } \\
\text { porto Ferreira consegue aumentar de } 30 \% \text { para } 80 \% \text { se conseguir mais } \\
\text { cacos de vidro; a inserção de caco na produção de garrafas economiza } \\
50 \% \text { de energia elétrica; }\end{array}$ \\
\hline & & & & Encaminhamentos & Nenhum \\
\hline & & & & Dados fornecidos & $\begin{array}{l}250 \text { reais/t o transporte e } 250 \text { reais/t o preço do material sem } \\
\text { nenhum tratamento, dessa forma é viável a reciclagem do vidro. }\end{array}$ \\
\hline \multirow{4}{*}{ 17/out } & \multirow{4}{*}{ Representante } & \multirow{4}{*}{ ABIVIDRO } & \multirow{4}{*}{$\begin{array}{l}\text { Entrevista } \\
\text { pessoal }\end{array}$} & Tema: & Possível solução para a reciclagem do vidro no Distrito Federal \\
\hline & & & & $\begin{array}{l}\text { Informações } \\
\text { fornecidas }\end{array}$ & Nenhum \\
\hline & & & & Encaminhamentos & $\begin{array}{l}\text { E-mail: Stefan@abividro.org.br telefone } 11983970123 \text { (disponível na } \\
\text { quinta pela manhã) engenheiro de logística do vidro. }\end{array}$ \\
\hline & & & & Dados fornecidos & Nenhum \\
\hline \multirow{4}{*}{ 31/out } & \multirow{4}{*}{ Diretora } & \multirow{4}{*}{ SLU } & \multirow{4}{*}{$\begin{array}{l}\text { E-mail, } \\
\text { telefone e } \\
\text { entrevista } \\
\text { pessoal }\end{array}$} & Tema: & $\begin{array}{l}\text { Os motivos de se considerar os resíduos de vidro como resíduos } \\
\text { indiferenciados e obter informações sobre volume de resíduos no DF. }\end{array}$ \\
\hline & & & & $\begin{array}{l}\text { Informações } \\
\text { fornecidas }\end{array}$ & $\begin{array}{l}\text { Existência do acordo setorial para embalagens em geral, informou que } \\
\text { a ABIVIDRO não está participando do acordo e o poder público } \\
\text { municipal e distrital não foi comunicado e não teve participação. } \\
\text { Informou que o SLU não pode tomar atitudes com relação aos } \\
\text { resíduos de vidro pois é de responsabilidade do setor privado de } \\
\text { acordo com a PNRS. O SLU não pode gastar dinheiro público se } \\
\text { responsabilizando por produtos que fazem parte da coleta seletiva. } \\
\text { Redução } 12 \% \text { para 1\% do ICMS no transporte interestadual de } \\
\text { resíduos (CONVÊNIO ICMS 7, DE } 5 \text { DE ABRIL DE 2013). }\end{array}$ \\
\hline & & & & Encaminhamentos & $\begin{array}{l}\text { Prometeu solicitar as informações ao Paulo Celso (Diretor técnico do } \\
\text { SLU) }\end{array}$ \\
\hline & & & & Dados fornecidos & $\begin{array}{l}\text { Custo para coleta seletiva: } \mathrm{R} \$ 190,00 / \mathrm{t} \text {; custo do transporte de } \\
\text { resíduos coletados: } \mathrm{R} \$ 100,00 / \mathrm{t} \text {; custo para aterrar: } \mathrm{R} \$ 90,00 / \mathrm{t}\end{array}$ \\
\hline
\end{tabular}




\begin{tabular}{|c|c|c|c|c|c|}
\hline \multirow{4}{*}{$20 / \mathrm{fev}$} & \multirow{4}{*}{ Gerente } & \multirow{4}{*}{$\begin{array}{c}\text { Empresa Green } \\
\text { Ambiental }\end{array}$} & \multirow{4}{*}{$\begin{array}{l}\text { E-mail e } \\
\text { entrevista } \\
\text { pessoal. }\end{array}$} & Tema: & Forma de trabalho da Empresa \\
\hline & & & & $\begin{array}{l}\text { Informações } \\
\text { fornecidas }\end{array}$ & $\begin{array}{l}\text { Os vidros de embalagem são recolhidos por meio de contêineres } \\
\left(5 \mathrm{~m}^{3}\right) \text { ou em tambores plásticos. As embalagens de vidro são } \\
\text { recolhidas como resíduos de vidro misto, com apenas contaminantes } \\
\text { inerentes da própria embalagem, como tampas, rótulos etc. os } \\
\text { resíduos são armazenados em baias, e são quebrados por uma } \\
\text { escavadeira. Alguns contaminantes, como sacolas, lâmpadas ou } \\
\text { outros contaminantes maiores são retirados manualmente. Existe } \\
\text { uma parceria exclusiva com a fábrica Owens Illinois. Paulo tem } \\
\text { objetivo de ampliar as instalações, e instalar esteira transportadora e } \\
\text { triturador de resíduo. Realizam uma pré separação retirando louças e } \\
\text { lâmpadas caso existam no meio do material. }\end{array}$ \\
\hline & & & & Encaminhamentos & Nenhum \\
\hline & & & & Dados fornecidos & $\begin{array}{c}\text { Possuem } 10 \text { contêineres; Owens Illinois que paga RS 280,00 a } \\
\text { tonelada do material }\end{array}$ \\
\hline \multirow{3}{*}{$13 /$ mar } & \multirow{3}{*}{ Gerente } & \multirow{3}{*}{ Green Ambiental } & \multirow[b]{2}{*}{$\begin{array}{l}\text { Telefone, e- } \\
\text { mail, } \\
\text { Questionário } \\
\text { e entrevista } \\
\text { pessoal }\end{array}$} & Tema: & Forma de trabalho da Empresa e proposta de otimização \\
\hline & & & & $\begin{array}{l}\text { Informações } \\
\text { fornecidas }\end{array}$ & $\begin{array}{l}\text { Em média os contêineres demoram sete dias para ser coletados, } \\
\text { porém existem lugares que esse tempo chega a } 15 \text { dias, como em } \\
\text { condomínios habitacionais, onde o consumo de embalagens é menor. } \\
\text { Os locais com coleta mais frequente são os bares, restaurantes e } \\
\text { shoppings cerca de cinco dias e em cooperativas que a coleta é } \\
\text { realizada de três em três dias, como por exemplo na capital } \\
\text { recicláveis. Os gastos para coletar os resíduos são elevados e o } \\
\text { retorno é baixo. Os gastos no transporte e as variações no preço do } \\
\text { diesel afetam consideravelmente o lucro da empresa. }\end{array}$ \\
\hline & & & & Encaminhamentos & Nenhum \\
\hline
\end{tabular}




\subsection{QUESTIONÁRIO}

\subsubsection{GREENAMBIENTAL}

Formulário de Diagnóstico da Forma de trabalho da empresa

Data:

Nome da Empresa:

Telefone:

Nome do entrevistado:

1. Em média quanto tempo demora para encher um contêiner?

( ) sete dias

( )14 dias

( )30 dias

( ) outro

2. Quais os contêineres que geralmente demoram mais para encher?

3. Quais os contêineres que geralmente enchem mais rápido?

4. Existe alguma outra forma de coletar os resíduos de vidro além dos contêineres?

5. Qual consumo em média dos caminhões que realizam a coleta dos contêineres? 
9.3. IMAGENS

9.3.1. DIMENSÕES CONTAINER
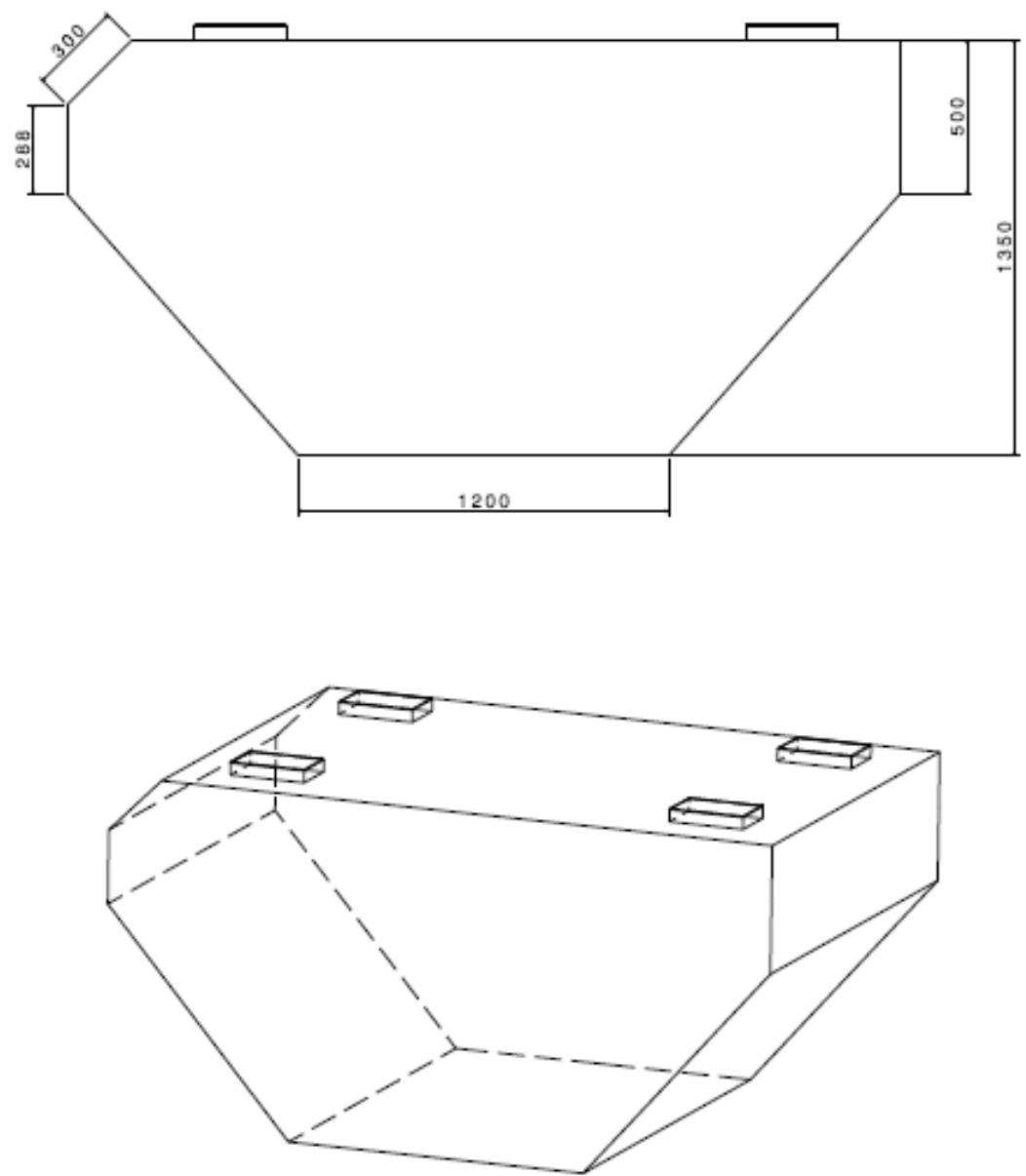

Figura 37. Dimensões físicas do container

\subsubsection{POLIGUINDASTE DUPLO}

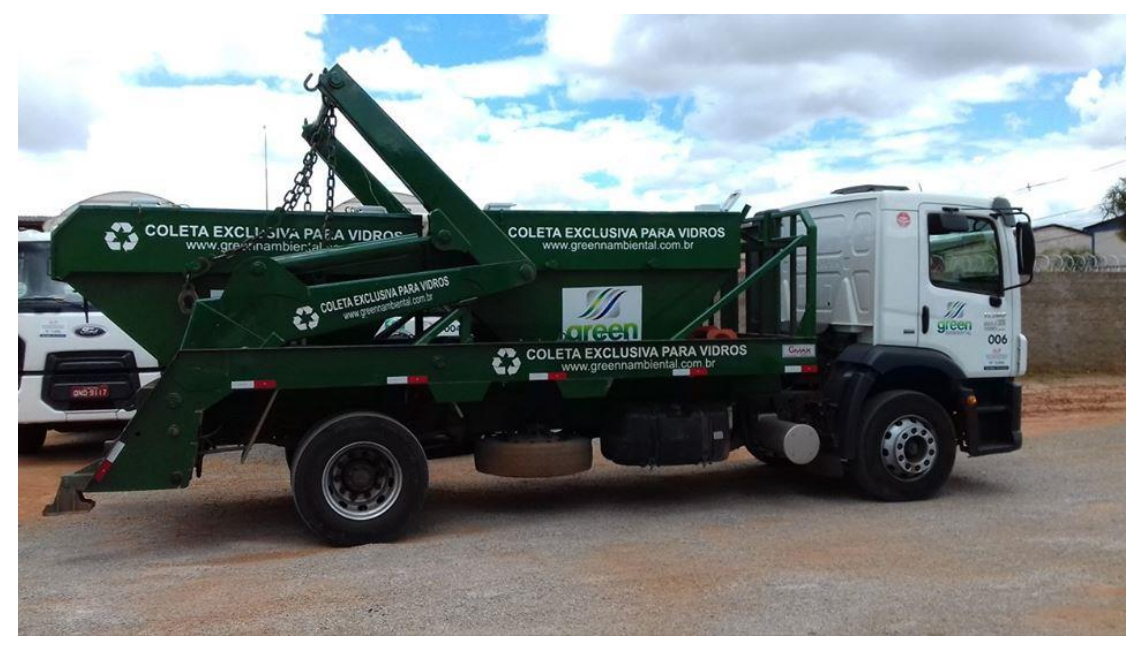

Figura 38. Caminhão Poliguindaste Duplo Articulado, modelo Constalation 17.280 


\subsubsection{DIMENSÕES DA CAIXA DE PROTEÇÃO}
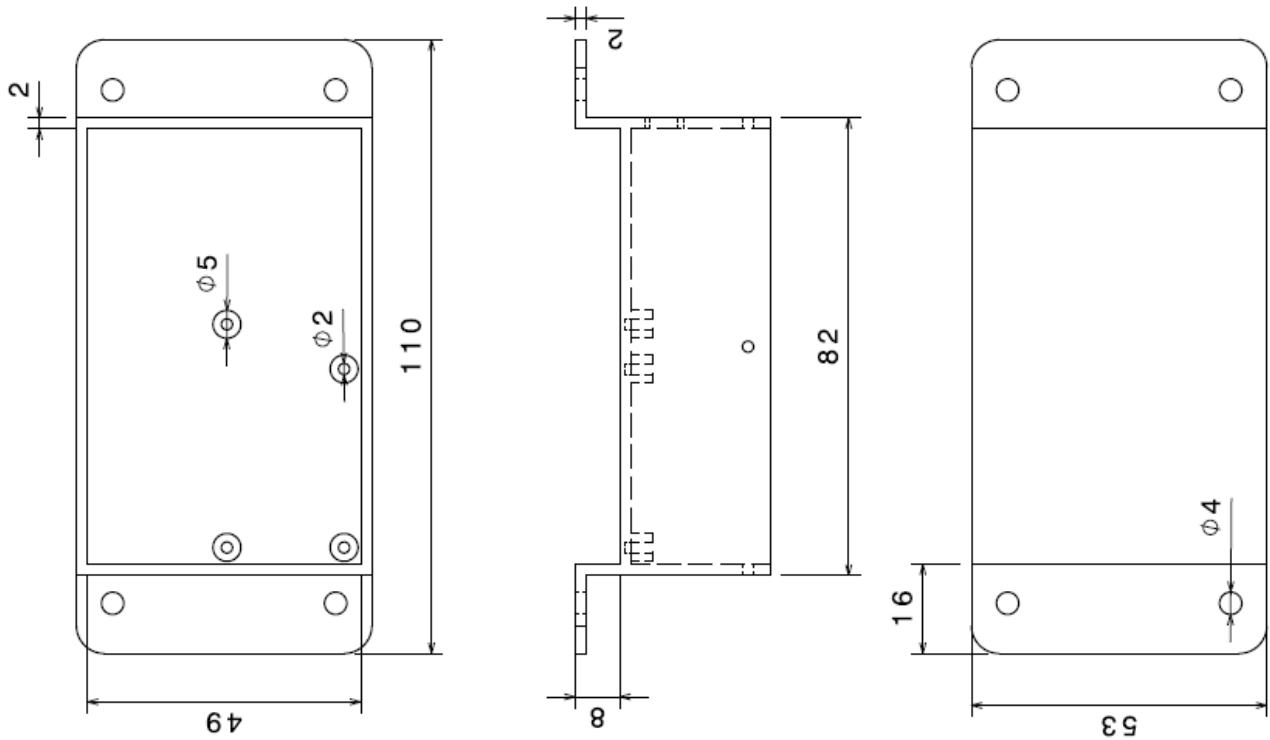

Figura 39. Dimensões caixa de proteção

\subsubsection{DIMENSÕES TAMPA DA CAIXA DE PROTEÇÃO}
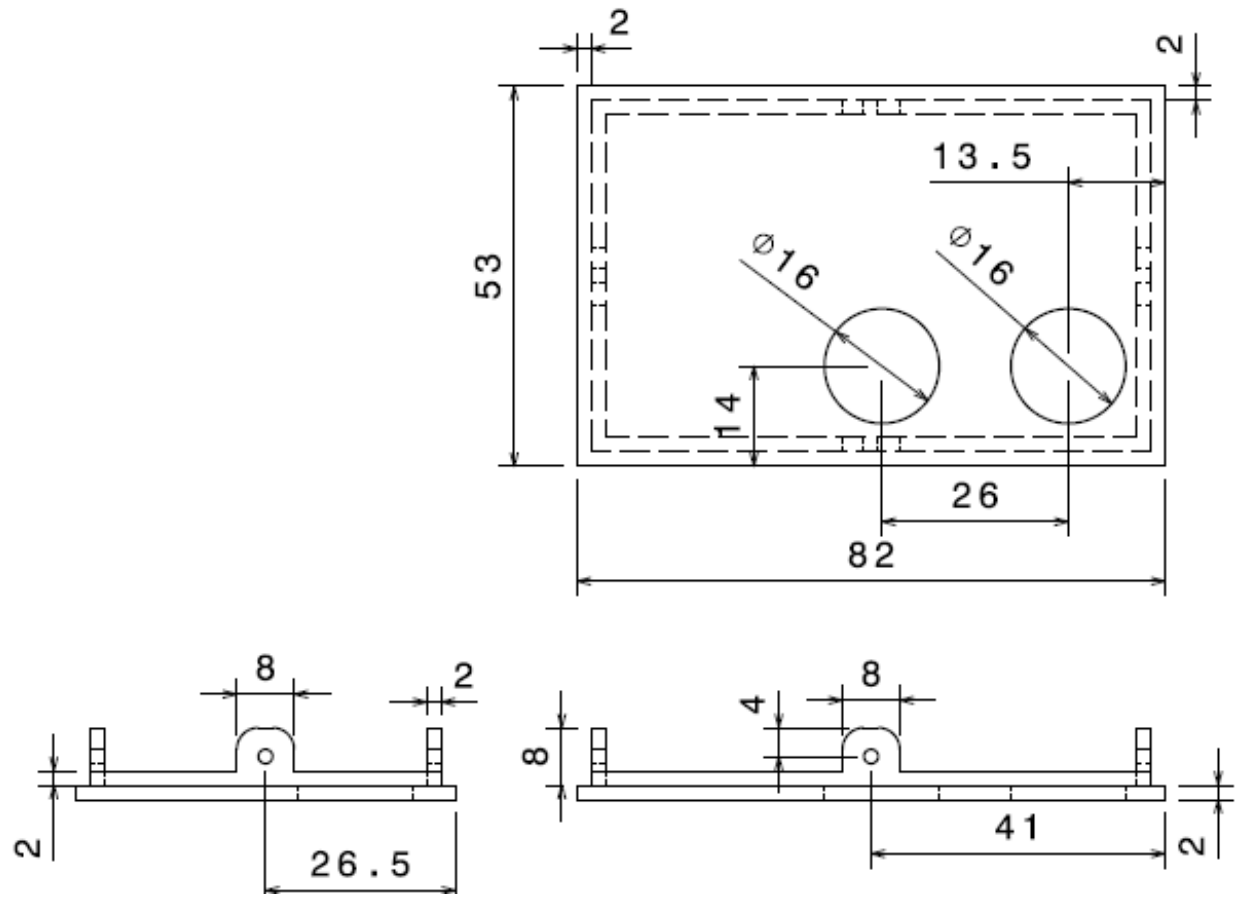

Figura 40. Dimensões tampa da caixa de proteção 


\subsubsection{FLUXOGRAMAS DAS SIMULAÇÕES DA PROPOSTA}
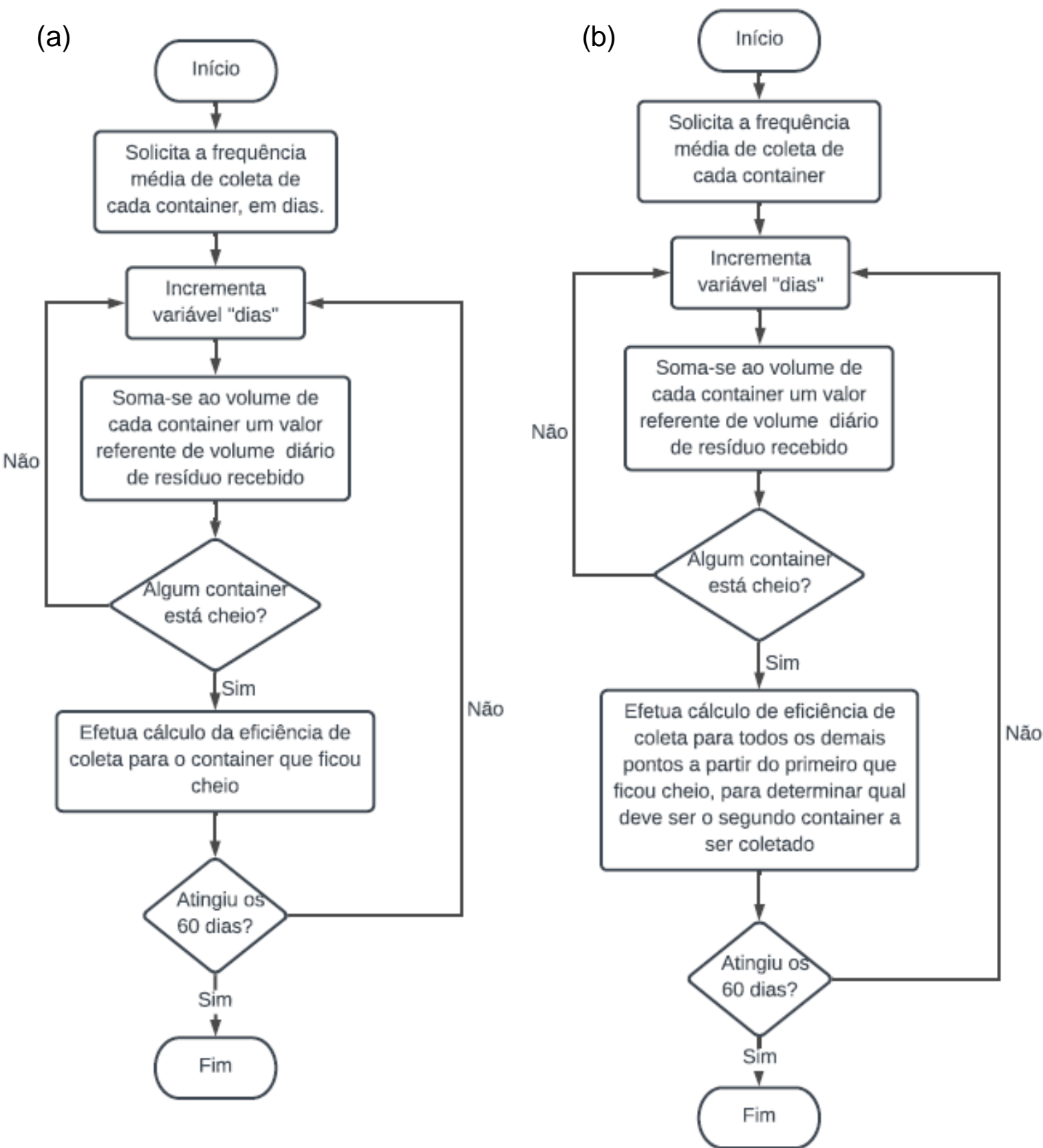

Figura 41. Fluxogramas da forma tradicional (a) e forma otimizada (b) 